www.volsu.ru

DOI: https://doi.org/10.15688/nav.jvolsu.2021.1.7

UDC $930.26(270+571)$

(c)

LBC 63.48(2)

Submitted: 07.02.2021

Accepted: 27.05 .2021

\title{
SWORDS AND DAGGERS WITHOUT A METAL POMMEL FROM THE MEOTIAN SITES OF THE RIGHT BANK OF THE KUBAN
}

\author{
Natalya Yu. Limberis \\ Kuban State University, Krasnodar, Russian Federation \\ Ivan I. Marchenko \\ Kuban State University, Krasnodar, Russian Federation \\ Artem V. Kondratenko \\ Kuban State University, Krasnodar, Russian Federation
}

\begin{abstract}
The article is devoted to typology and chronology of swords and daggers without a metal pommel from the Maeotian cemeteries of the right bank of the Kuban. We took into account 57 pieces of this type of weapon from closed complexes. In this paper, we use the typological scheme of A.M. Khazanov, developed on the materials of the Sarmatian armament. The Maeotian swords and daggers of mentioned group are divided into three types: 1 swords and daggers with a rain-guard; 2 - swords and daggers without a rain-guard, the blade and the hilt make an obtuse angle; 3 - swords and daggers without rain-guards, the blade and the hilt make a right angle. Metal tangs of hilts differ by shape and size; thus they are divided into two variants: "a" - rectangular or triangular; "b" - a long pin. The swords of the " $\mathrm{a}$ " variant had wooden overlays on the handles, sometimes fastened with rivets or winding, and the handles of the " $\mathrm{b}$ " variant swords were mounted on a tang. Chronological dating of the burials indicates that bladed weapon of this type appears among the Maeotians of the Kuban right bank in the beginning of the $1^{\text {st }}$ cent. AD and remains there until the middle of the $3^{\text {rd }}$ cent. AD. And the main time of its use is the $1-2$ cent. A.D. Swords and daggers of all types from Maeotian assemblages have existed at the same time, just like ones from the Sarmatian burials of the Lower Volga region. But, unlike the Sarmatian sites with no predominance of any particular sword type, the Maeotians show clear advantage of type 2 blades.
\end{abstract}

Key words: Kuban region, Maeotians, burial ground, sword, dagger, typology, chronology.

Citation. Limberis N.Yu., Marchenko I.I., Kondratenko A.V., 2021. Mechi i kinzhaly bez metallicheskogo navershiya iz meotskih pamyatnikov pravoberezh'ya Kubani [Swords and Daggers Without a Metal Pommel from $\therefore$ the Meotian Sites of the Right Bank of the Kuban]. Nizhnevolzhskiy Arkheologicheskiy Vestnik [The Lower Volga Archaeological Bulletin], vol. 20, no. 1, pp. 103-152. DOI: https://doi.org/10.15688/nav.jvolsu.2021.1.7

УДК 930.26(270+571)

Дата поступления статьи: 07.02.2021

ББК 63.48(2) Дата принятия статьи: 27.05.2021

\section{МЕЧИ И КИНЖАЛЫ БЕЗ МЕТАЛЛИЧЕСКОГО НАВЕРШИЯ ИЗ МЕОТСКИХ ПАМЯТНИКОВ ПРАВОБЕРЕЖЬЯ КУБАНИ}

\author{
Наталья Юрьевна Лимберис \\ Кубанский государственный университет, г. Краснодар, Российская Федерация \\ Иван Иванович Марченко \\ Кубанский государственный университет, г. Краснодар, Российская Федерация \\ Артем Викторович Кондратенко \\ Кубанский государственный университет, г. Краснодар, Российская Федерация
}


Аннотация. Статья посвящена типологии и хронологии мечей и кинжалов без металлического навершия из меотских грунтовых могильников правобережья Кубани. Нами учтено 57 экземпляров этого вида оружия из закрытых комплексов. В работе мы используем типологическую схему А.М. Хазанова, разработанную на материалах сарматского вооружения. Меотские мечи и кинжалы этого отдела относятся к трем типам: тип 1 - мечи и кинжалы с перекрестием; тип 2 - мечи и кинжалы без перекрестья, клинок которых переходит в черенок под тупым углом; тип 3 - мечи и кинжалы без перекрестья, клинок которых переходит в черенок под прямым углом. Металлические черенки рукоятей отличаются формой и размерами и разделены на два варианта: «а» - прямоугольные или треугольные; «б» - длинный штырь. Мечи варианта «а» имели деревянные накладки на рукояти, которые иногда крепились с помощью заклепки или обмотки, а рукояти мечей варианта «б» насаживались на штырь. Хронологическая атрибуция погребений показывает, что клинковое оружие этого типа появляется у меотов правобережья Кубани в начале I в. н.э. и бытует вплоть до середины III в. н.э. Причем основное время их использования приходится на I-II н.э. Как и в сарматских погребениях Нижнего Поволжья, в меотских комплексах мечи и кинжалы всех типов синхронны. Но, в отличие от сарматских памятников, где не отмечается преобладание какого-то одного типа мечей, у меотов явное преимущество имели клинки типа 2.

Ключевые слова: Прикубанье, меоты, грунтовый могильник, меч, кинжал, типология, хронология.

Цитирование. Лимберис Н. Ю., Марченко И. И., Кондратенко А. В., 2021. Мечи и кинжалы без металлического навершия из меотских памятников правобережья Кубани // Нижневолжский археологический вестник. Т. 20, № 1. С. 103-152. DOI: https://doi.org/10.15688/nav.jvolsu.2021.1.7

Для меотского клинкового оружия первых веков н.э. характерны мечи без металлического навершия, рукояти которых откованы вместе с клинком. Существует несколько типологических схем этой категории мечей, основанных на сарматском материале. Нам представляется, что схема, предложенная А.М. Хазановым, работает и в настоящее время, и мы будем, как и большинство исследователей, придерживаться его типологии [Хазанов, 1971, с. 17]. Меотские мечи и кинжалы этого отдела относятся к трем типам. В тип 1 включены мечи и кинжалы с перекрестием. К типу 2 отнесены мечи и кинжалы без перекрестья, клинок которых переходит в черенок под тупым углом, и в тип 3 объединены мечи и кинжалы без перекрестья, клинок которых переходит в черенок под прямым углом. Металлические черенки рукоятей отличаются формой и размерами, поэтому мы предлагаем разделить их на два варианта: прямоугольные или треугольные - «а», длинный штырь - «б». Мечи варианта «а» имели деревянные накладки на рукояти, которые иногда крепились с помощью заклепки или обмотки, скорее всего, кожаными ремешками, а рукояти мечей варианта «б» насаживались на штырь. Возможно, они имели катушкообразную форму, но это только предположение, так как даже тлен от них не дает возможности восстановить форму рукоятей.
Нами учтено 57 экземпляров этого вида оружия из закрытых комплексов меотских грунтовых могильников городищ, расположенных на правобережье Кубани: Старокорсунского № 2 (СК-2), Старокорсунского № 3 (СК-3), хут. Ленина № 1 (Л-1), Спорное (СП), Усть-Лабинского № 2 (УЛ-2), Елизаветинского № 2 (ЕЛ-2), Воронежского № 3, Пашковского № 5 (Пашк.-5), a также Пашковского могильника № 2 (Пашк.-2), относящегося к одноименному городищу № 1 . Среди мечей встречаются как длинные (от 75 см до $103 \mathrm{~cm}$ ), так и более короткие (от $45 \mathrm{~cm}$ до 70 см). Кроме этого, выделяется группа кинжалов, длина которых не превышает 40 см. Размерные характеристики мечей и кинжалов приведены в таблице 1.

Мечи и кинжалы типа 1 (рис. 1, 4), всего 10 экз. из комплексов Л-1 № 33/1980, № 20/1981, № 359/1981; СК-2 № 326в, № 2303, № 6133; СК-3 № 348, № 504; ЕЛ-2 № 31/1978, № 93/1978. Перекрестья большей части мечей - брусковидные, и только у двух экземпляров - ромбовидные (Л-1 № 33/1980 - железное, СК-2 № 6133 - бронзовое с вырезом в верхней части, имитирующее нефритовое).

Мечи типа 2 (рис. 2), всего 24 экз.: Л-1 № 64/1980, № 138/1981, № 227/1981, № 255/1981, № 289/1981, № 306/1981, № 364/1981, № 377/1981, № 419/1981, № 27/1983; СК-2 № 33в, № 35в, № 325в, № 329в, № 3793, № 4823, № 5543; CK-3 № 13, № 266, № 270, № 294, № 511; СП № 161, Пашк.-5 № 2/1972. 
Мечи и кинжалы типа 3 (рис. 3, 4), всего 16 экз.: Л-1 № 12/1981, № 140/1981, № 174/1981, № 4/1983; СК-2 № 2183, СК-3 № 4, № 64, № 255, № 315, № 338, № 347; СП № 104, УЛ-2 № 81/1938, ЕЛ-2 № 13/2013, № 140/2013; Пашк.-1 № 1.

Есть также несколько экземпляров мечей, тип которых не установлен. Относительно мечей из Вор-3 № 7/1966, № 59/1966, № 172/1967, № 207/1967, УЛ-2 № 13/1931, № 2/1944 известно только по краткой информации из публикаций, полевым фотографиям и отчетам Н.В. Анфимова без рисунков. Также неясен тип меча из погребения Л-1 № 392/1981, так как он был плохой сохранности и разрушился при снятии. Все эти мечи - без перекрестия и, значит, относились либо ко 2-му, либо к 3-му типу.

На наш взгляд, для того чтобы установить время появления и период использования мечей без металлического навершия меотами правобережья Кубани, целесообразно, по возможности, более точно продатировать погребения, в которых они были найдены. Хронология комплексов в большинстве случаев опирается на те предметы инвентаря, которые принято считать относительно надежными хроноиндикаторами, - в основном это бронзовые фибулы разных типов, причем очень немногие из них имеют узкие датировки. Встречаются также импортные стеклянные сосуды, хронология которых для памятников местного населения Прикубанья выглядит достаточно убедительно. Во многих погребениях с мечами нет разработанных хроноиндикаторов, зато присутствуют сероглиняные сосуды, которые в меотских памятниках часто сопровождаются фибулами, зеркалами или другими предметами, имеющими более-менее определенные рамки бытования. По этой причине некоторые типы местной керамики вполне могут служить опорными ориентирами для хронологии комплексов, где нет других датирующих вещей.

Наиболее ранним среди известных в настоящее время меотских комплексов с мечами без металлического навершия является погребение Л-1 № 306, в котором вместе с мечом типа 2а был найден стеклянный амфориск (рис. 22,7,10), изготовленный в технике песчаного сердечника. Хронология подобных сосудов из Сиро-Палестинского региона и Египта определяется в пределах II - середины I в. до н.э. [Grose, 1989, p. 170, type III:2A, No. 170], а сосудов поздней кипрской группы I в. до н.э. - первой половиной I в. н.э. [Hayes, 1975, p. 15]. В некрополе Самофракия период их бытования первоначально ограничивали периодом правления Августа [Dusenbery, 1967, p. 34-49], позже - временем около 25 г. до н.э. [Dusenbery, 1998, p. 234, 1069-1070, No. S14324, S144-11, S167-5]. Близкого типа амфориск из Пантикапея Н.З. Кунина отнесла к началу І в. н.э. [Кунина, 1997, с. 253, № 37]. Этим же временем, учитывая формы меотских сероглиняных сосудов, мы датировали погребение № 306 [Лимберис, Марченко, 2003, с. 110-111, № 60; Marčenko, Limberis, 2008, S. 386, Taf. 131, Kat-Nr. 120].

Меч типа 1а найден в погребении ЕЛ-2 № 31/1978 (рис. 30) вместе с литыми стеклянными скифосом и чашей, которые позволили нам отнести этот комплекс к первой половине I в. н.э. [Лимберис, Марченко, 2003, c. 108, 110, 183, № 107,1,2; Marčenko, Limberis, 2008, S. 389, Taf. 195, Kat.-Nr. 188].

Узкую хронологию имеет погребение ЕЛ-2 № 140/2013 с мечом типа 3б, откуда происходит фибула-брошь без эмали в виде павлина с широким хвостом, украшенным по периметру врезными «глазками». Э. Эттлингер выделила эти броши в тип 46 и датировала второй четвертью - серединой I в. н.э. [Ettlinger, 1973, S. 124]. К этому же времени аналогичные застежки относит В.В. Кропотов [Кропотов, 2010, с. 305].

Погребение Л-1 № 419/1981 с мечом типа 2a (рис. 27,5-10) ранее было нами широко датировано по ребристой стеклянной чаше Isings 3c/AR 2.3 [Isings, 1957, p. 20-21; Rütti, 1991, S. 40] I в. н.э. [Лимберис, Марченко, 2003, c. 110, № 64; Marčenko, Limberis, 2008, S. 386, Taf. 128, Kat.-Nr. 125]. Аналогичные чаши, согласно новым исследованиям коллекции стеклянных изделий из лагеря Август, датируются 15-50 гг. [Fünfschilling, 2015, S. 264$265,684]$, что позволяет сузить хронологию этого комплекса до второй - третьей четверти I в. н.э.

В погребении ЕЛ-2 № 13/2013 мечу типа $3 \sigma$ сопутствовала фибула с выпуклой пластинчатой спинкой и кнопкой на конце приемника 
серии I, варианта 2, хронологию которых В.В. Кропотов определяет периодом формирования позднесарматской культуры, то есть «большей частью» II в. н.э. [Кропотов, 2010, c. 212-213]. По наблюдениям В.М. Косяненко, пластинчатые экземпляры с кнопкой на конце приемника из некрополя Кобякова городища относятся к I в. н.э. [Косяненко, 2008, c. 92-93]. Выводы исследовательницы построены на материалах памятника оседлого меотского населения Нижнего Дона, поэтому ее датировка является для нас более предпочтительной. Елизаветинское погребение мы считаем возможным отнести к I в. н.э.

В погребениях СК-2 № 35в с мечом типа 2а (рис. 13,11 ) и Л-1 № 289 с кинжалом того же типа (рис. 25,1-4) датирующими находками являются железные бритвы (рис. 13,8 ; 25,3). Такие бритвы встречены в Старокорсунском могильнике № 2 вместе с лучковыми фибулами группы 4, серии 1 [Кропотов, 2010, с. 68-74]. В погребении СК-2 № 29в была найдена фибула варианта 1 , в погребении СК-2 № 139в - варианта 2 и, кроме нее, еще пластинчатая фибула с завитком на конце приемника, что дало нам основание датировать бритвы I в. н.э. Бритвы происходят также из двух комплексов I в. н.э. некрополя городища Спорное (№ 98, 143) с мечами с кольцевидными навершиями [Лимберис, Марченко, 2019a, с. 206, рис. 1,8, 6,6]. Этим же временем, скорее всего, нужно датировать и комплексы СК-2 № 35в и Л-1 № 289.

В комплект вооружения из погребения СК-2 № 4823 вместе с мечом типа 2а входили наконечник копья и набор наконечников стрел (рис. 17). Наконечник копья с удлиненно-ромбовидным пером с прогнутыми краями и длинным уплощенным острием относится к типу III, 4, IV, 1 по нашей классификации. Данный вариант наконечников копий встречается в комплексах второй половины II в. до н.э. и в I-II вв. н.э. Это погребение мы датировали I в. н.э. [Лимберис, Марченко, 2006, с. 171]. В погребениях Л-3 № 53 и № 58 аналогичным копьям сопутствовали кружки с прямоугольной площадкой и выступом на ручке, основное время бытования которых, вероятнее всего, ограничивается I в. н.э. Среди черешковых наконечников стрел находился один втульчатый, что может указывать на более раннюю дату, возможно, на начало этого столетия. Не исключено и вторичное использование этого наконечника, так как он имеет очень маленькие размеры, характерные для IV-III вв. до н.э.

Разрушенное в древности погребение Л-1 № 227/1981 с мечом типа 2б может быть датировано по набору усеченно-биконических бус из глухого голубого стекла, которые Е.М. Алексеева считает характерными для I в. н.э. [Алексеева, 1978 , с. 69 , тип 101 , рис. 15$]$. Хотя такие бусы, по нашим наблюдениям, не являются надежным хроноиндикатором, других данных для датировки комплекс не имеет.

Три меча без перекрестия и металлического навершия происходят из погребений четвертой хронологической группы второй половины I в. до н.э. - II в. н.э. Усть-Лабинском могильника № 2. Такие мечи, как считал Н.В. Анфимов, появились на Кубани и Боспоре на рубеже эр и были господствующей формой в первые века н.э. [Анфимов, 1951, с. 202]. Мечи из погребений УЛ-2 № 13/1931 и № 2/1944 относятся к типу 2 или $\mathbf{3}$, варианты их неизвестны. Опубликован только рисунок меча типа 3б из погребения № 81/1938 г., вместе с которым была найдена бронзовая лучковая подвязная фибула, два керамических сосуда и костяная ворворка (рис. 29,1-6) [Анфимов, 1951 , с. 197,198 , рис. $18,1,9]$. Эту фибулу В.В. Кропотов отнес к серии I, варианту 2 [Кропотов, 2010, с. 72, 89, № 208], что позволяет датировать комплекс второй половиной I - началом II в. н.э.

Погребение ЕЛ-2 № 93/1978 (рис. 29,7-13) с мечом типа 1а можно датировать по находке бронзовой подвески-«ведерка» в виде полого цилиндра, с петлей для подвешивания [Анфимов, 1984, с. 95, табл. ХІІ,30]. Такие подвески в памятниках Предгорного Крыма относятся к І в. н.э., а в более поздних комплексах они не встречаются [Труфанов, 2009, c. 231 , рис. $65,17,20]$. Аналогичная подвеска была найдена в погребении СК-3 № 81 вместе с двумя лучковыми подвязными фибулами серии I, варианта 2 и одной застежкой серии IV, варианта 2, что позволяет датировать данный комплекс второй половиной I началом II в. н.э. [Кропотов, 2010, с. 74, 161]. Таким образом, хронологию елизаветинского погребения с мечом также можно ограни- 
чить I в. н.э., возможно, началом следующего столетия.

Особый интерес представляет меч типа 1а из погребения СК-2 № 6133 (рис. 18, 19), который имеет бронзовое литое ромбовидное перекрестие с прямоугольным вырезом сверху и выступом снизу. Длинные мечи с короткими ромбическими перекрестиями из бронзы, железа или нефрита и длинным черенком для рукояти известны в сарматских памятниках Волго-Донских степей и на сопредельных территориях. В.Е. Маслов предлагал разделить мечи с бронзовыми перекрестиями на две группы: с перекрестиями, близкими нефритовым (с вырезом сверху и центральным выступом снизу), и с прямыми, ромбовидными в сечении перекрестиями, не имеющими центрального выступа [Маслов, 1999, с. 221]. А.С. Скрипкин считает, что разделение на две группы по форме перекрестия не имеет большого значения, так как все подобные мечи независимо от материала перекрестий восходят к единой традиции в их изготовлении. Исследователь связывает их распространение в сарматской среде с восточными (китайскими) инновациями. Самые ранние мечи он датирует II-I вв. до н.э., а поздние - IIIII вв. н.э. [Скрипкин, 2000, с. 18, 20, 31]. В недавно вышедшей совместной статьеА.С. Скрипкин и В.М. Клепиков небезосновательно считают, что мечи с кольцевым навершием и мечи без металлического навершия появляются в данном регионе в результате миграционных процессов, исходной территорией которых были центральноазиатские районы, соседствующие с Китаем [Скрипкин, Клепиков, 2020, с. 214-215].

По мнению С.И. Безуглова, прототипами мечей с подобными перекрестиями были, безусловно, китайские изделия [Безуглов, 2000, с. 176]. О восточном происхождении таких мечей пишет и А.В. Симоненко [Симоненко, 2010, с. 56]. Новой находкой на правобережье Нижнего Подонья является меч с бронзовым перекрестием без выреза из погребения 3 кургана 7 могильника «Попов-І», которое авторы публикации относят «к самому концу раннесарматского периода» и датируют временем, «близким к рубежу эр» [Кропотов, Скворцов, 2020, с. 352-354, рис. 5].

Для Прикубанья мечи с бронзовыми перекрестиями являются уникальными находка- ми. Кроме меча из Старокорсунского могильника № 2 нам известен еще только один меч из кургана в станице Динской (раскопки Е.А. Ярковой в 1973 г.). Этот сарматский комплекс датируется І в. до н.э. На основании сохранности фрагментов клинка и не очень качественного полевого чертежа меч был отнесен к коротким [Марченко, 1996, с. 56, рис. 96,2]. Однако не исключено, что меч из Динской мог быть и длинным.

Погребению СК-2 № 6133 нами была посвящена специальная статья [Лимберис, Марченко, 2012, с. 144-154]. Вместе с мечом в этом богатом комплексе найдена конская узда с набором серебряных фаларов: большим нагрудным в виде чаши, двумя наплечными, украшенными вихревой розеткой, и девятью малыми в виде львиных масок. В комплект упряжи входило семь пар железных удил. Найдены также железный кинжал без металлического навершия и перекрестия (тип 3a), ножи, мелкие детали портупейного набора (бронзовые и железные подвески, пряжки, зажимы) и украшения (золотой браслет, бронзовый перстень). Анализ инвентаря позволил нам датировать этот комплекс второй половиной I началом II в. н.э. На основании краниометрических данных была установлена сарматская принадлежность погребенного [Лимберис, Марченко, 2012, с. 144, 154]. Поэтому меч из старокорсунского комплекса можно считать сарматским по принадлежности.

В погребении СК-3 № 347 (рис. 11,1-5) с мечом типа 3а хроноиндикаторами являются лучковая подвязная фибула серии I, варианта 3 первой половины - середины II в. н.э. [Амброз, 1966, с. 49-50; Кропотов, 2010, c. 74-75] и стеклянный бальзамарий формы AR 129, который датируется временем Тиберия-Траяна и, вероятно, позже, а в абсолютных датах - с 20-70/80 гг. до 100 г. н.э. [Rütti, 1991, S. 52, Abb. 35; Fünfschilling, 2015, S. 403, Formentafel 3]. На Боспоре такие бальзамарии (тип I, 2, А) встречаются в основном в комплексах первой половины I в. н.э. и реже в более поздних [Кунина, Сорокина, 1972, c. 157, рис. 1]. Эти находки позволили нам отнести данный комплекс ко второй половине I в. н.э. [Лимберис, Марченко, 2003, с. 115, № 96; Marčenko, Limberis, 2008, S. 388, Taf. 181, Kat.-Nr. 173]. 
В комплексе СК-3 № 4 (рис. 5,1-6) вместе с кинжалом типа 3а найдена фибула типа Альмгрен 69 [Almgren, 1923, S. 34, Fig. 69], по которой мы первоначально датировали комплекс второй половиной I в. н.э. [Marčenko, Limberis, 2008, S. 387, Taf. 158, Kat.-Nr. 151]. В лагере Август соответствующий тип датируется второй четвертью - концом I в. н.э. [Riha, 1994, Тур 2.9, Taf. 78]. B.В. Кропотов отнес такие застежки к форме 1 сильно профилированных фибул с расширенной головкой. Автор отмечает, что западноевропейская схема развития не всегда находит подтверждение в древностях Свободной Европы (Словении и Дакии), где такие фибулы датируются концом I - началом II в. н.э. и, опираясь на три находки из Крыма и Нижнего Дона, предлагает датировать этот тип застежек периодом формирования позднесарматской культуры, то есть «большей частью II в. н.э.» [Кропотов, 2010, с. 257-259]. Для уточнения датировки фибул Альмгрен 69 следует обратиться к комплексам вещей из погребений, на которые ссылается автор. В могиле № 82 (первая камера подбоя) Неаполя Скифского нет вещей, которые могли бы скорректировать дату застежки. Во второй камере (могила 85) найдены сильно профилированные фибулы с бусинами на дужке II серии, лучковая I серии, варианта 3 и смычковая. Причем в обеих камерах совершались подзахоронения. У нас нет оснований считать одновременными эти две могилы, как полагает В.В. Кропотов [Кропотов, 2010 , с. 262 , № 16]. Да и сам исследователь этого памятника Э.А. Сымонович считал их разновременными и могилу 85 датировал I в. н.э. [Сымонович, 1983, с. 70-72]. Во втором комплексе (разрушенное погребение из Левенцовского карьера г. Ростов-на-Дону), кроме фибулы этого типа, было найдено орнаментированное зеркало-подвеска с боковым ушком. Такие зеркала, как сейчас установлено, встречаются и в I в. н.э. [Косяненко, 2008, с. 84-104, 108-117; Лимберис, Марченко, 2018, c. 214, рис. 9]. Автор публикации датировала этот комплекс концом Ів. н.э. [Косяненко, 1989, c. 59-61, рис. $1,17,18]$. В третьем комплексе (могила 25 могильника у с. Красная Заря), который приводит В.В. Кропотов, встречены две лучковые подвязные фибулы серии I, варианта 2 , по которым авторы публикации да- тировали это погребениевторой половиной I в. н.э. [Волошинов и др., 2007, с. 303-307, рис. 1,25, $4,19,5]$. Таким образом, говорить о большом запаздывании фибул типа Альмгрен 69 нет оснований. Учитывая время появления их в Дакии, погребение СК-3 № 4, вероятно, может относиться к концу I - началу II в. н.э.

В погребениях СК-3 № 13 с мечом типа 2 б (рис. 6,3-9), № 64 с кинжалом типа 3a (рис. 7,1-5), № 270 с мечом типа 2а (рис. 8,1-7), № 338 с мечом типа 3а (рис. 9,1-8), Л-1 № 364/1981 с мечом типа 2а (рис. 26,6-12) также были встречены одинаковые лучковые подвязные фибулы серии I, варианта 3, традиционная датировка которых - первая половина - середина II в. н.э. [Кропотов, 2010, с. 74-75]. Однако в погребении Л-1 № 364 присутствовал также стеклянный бальзамарий типа Isings 28b/AR 130.2, на основании которого хронология комплекса ранее была нами определена в пределах второй половины I - начала II в. н.э. [Лимберис, Марченко, 2003, с. 114,181 , рис. 27 , № 62; Marčenko, Limberis, 2008, S. 386, Taf. 133, Kat.-Nr. 122]. Уточненная хронология сосудов формы AR 130.2 в настоящее время ограничивается 50-100/120 гг. н.э. [Rütti, 1991, S. 52; Fünfschilling, 2015, S. 404, Formentafel 3]. Учитывая хронологию фибулы, комплекс Л-1 № 364 теперь предлагается датировать началом II в. н.э.

В погребении СК-3 № 511 с мечом типа 2б (рис. 10,6-9) найдены удила с колесовидными псалиями, овальные петли которых приварены к ступице псалия. Колесовидные псалии с круглыми приваренными петлями присутствуют в погребении СК-2 6133 второй половины I - начала II в. н.э. [Лимберис, Марченко, 2012, с. 153 , рис. $3,4,5,8,9]$. Другой датирующей находкой является пластинчатое колечко с пуансонным орнаментом. Такие украшения часто встречаются в меотских погребениях с лучковыми подвязными фибулами серии I, 1-3 вариантов. На этом основании датировку погребения можно ограничить I- первой половиной II в. н.э.

В погребении Л-1 № 377/1981 (рис. 24,4-9) вместе с кинжалом типа 2а был найден сероглиняный кувшин, который по некоторым характерным морфологическим признакам (валикообразный кольцевой поддон, ручка с продольным ребром) тяготеет к I в. до н.э. 
Набор бус в основном состоит из типов, появившихся еще в эллинистическую эпоху и продолжавших бытовать в римское время. Только две янтарные дисковидные бусины относятся к типу, зародившемуся в I в. н.э. и получившему распространение в более поздний период [Алексеева, 1978, с. 24, тип 11]. Эти скудные хронологические данные все же позволяют датировать погребение I в. н.э.

Погребение Л-1 № 359/1981 (рис. 26,1-5) с мечом типа 1а сопровождалось сероглиняным кувшином и красноглиняной чашей с двумя ручками. Аналогичный кувшин происходит из комплекса СК-2 № 28в, который датируется по стеклянному скифосу типа ІІІб, варианта 2 первой половиной I в. н.э. [Лимберис, Марченко, 2019б, с. 236-238]. Форма чаши, продолжающая традиции чернолаковой позднеэллинистической и раннеримской керамики [Rotroff, 1997, p. 119, fig. 23, No. 403, 404; Robinson, 1959, p. 10, 13-14, F29-32; Thompson, 1934, p. 370, 372, fig. 58, D17], весьма близка краснолаковому сосуду боспорского производства из погребения № 78 Цемдолинского некрополя, которое датируется по чаше и набору бус второй половиной I - началом II в. н.э. [Малышев, 2008 , с. 115,142 , рис. 107,78$]$. Хронология погребения Л-1 № 359/1981, скорее всего, не выходит за рамки I в. н.э.

В разрушенном погребении Л-1 № 392/1981 вместе с мечом неустановленного типа 2/3 находилось три красноглиняных сосуда (рис. 27,1-4). Наличие красноглиняной керамики выглядит несколько странным для меотских погребений первых веков н.э., но формы характерны для сероглиняных сосудов этого времени. Особенно показателен тип шаровидного горшочка без выделенного горла: такие сосуды являются частыми находками в погребениях, в том числе сопровождавшихся зеркалами-подвесками без орнамента. Аналогичные сероглиняные горшочки присутствуют в четвертой хронологической группе Усть-Лабинского могильника № 2 [Анфимов, 1951, рис. 17,8,9], причем один из них был найден в погребении УЛ-2 № 81/1938 с мечом типа 3б, которое по бронзовой лучковой подвязной фибуле серии I, варианта 2 было датировано нами второй половиной I началом II в. н.э. (обоснование его датировки см. выше). Хронологию же погребения
Л-1 № 392/1981, вероятно, можно ограничить I в. н.э.

Общая морфология кувшина со сливом из комплекса СК-2 № 325в с мечом типа 2a (рис. 11,6-14) указывает на I в. до н.э. І в. н.э. Горло и тулово этого сосуда раскрашены вертикальными полосами белой краски. Такой прием орнаментации характерен для керамики I-II в. н.э. В этом же погребении были найдены две бронзовые проволочные петельки с перевитым стержнем и маленькая бронзовая пряжка с заклепкой на рамке. Аналогичные предметы присутствуют среди многочисленного инвентаря в богатом комплексе СК-2 № 6133 второй половины I начала II в. н.э. [Лимберис, Марченко, 2012, c. 153,154 , рис. $5,19,22,25]$. Пряжка такой же конструкции была встречена и в узко датирующемся по римской фибуле погребении Ел.-2 № 140/2013 второй четверти - середины I в. н.э. (см. выше обоснование его датировки). Принимая во внимание тип кувшина, погребение СК-2 № 325в, скорее всего, нужно отнести к І в. н.э.

Близкий кувшин со сливом и миска с острым выступающим венчиком сопутствовали кинжалу типа 3а в погребении СК-2 № 2183 (рис. 14,1-5). Подобные кувшины были встречены в погребениях СК-3 № 237, СК-3 № 392 вместе с лучковыми подвязными фибулами серии I, вариантов 2 и 3 , и застежкой с завитком на конце приемника. Миска из погребения СК-2 № 2183 находит многочисленные параллели в комплексах с кружками с выделенным в основании горлом. Таким образом, по типам сероглиняных сосудов погребение СК-2 № 2183 можно датировать I - первой половиной II в. н.э.

К этому же периоду, скорее всего, относится и ограбленное в древности погребение СК-2 № 5543 (рис. 16,1-3), где, кроме такого же короткого кинжала типа 2a, сохранилась только бронзовая пряжка с железным язычком.

Из погребения СК-2 № 33в (рис. 12) с мечом типа 2а происходит сероглиняный кувшин с сильно стилизованной зооморфной ручкой. В погребении СП № 125 аналогичному кувшину сопутствовали меч с кольцевым навершием и другой инвентарь I в. н.э. [Лимберис, Марченко, 2019а, с. 206, рис. 2]. Такие же 
кувшины были найдены в погребениях СК-2 № 2733 и 6303 вместе с лучковыми подвязными фибулами серии I, варианта 3. Еще один кувшин этой формы, но с ручкой, имитирующей бронзовый шарнир, - с лучковой подвязной фибулой этой же серии, варианта 2, - в погребении СК-2 № 2843. Эти находки дают нам основание датировать подобные кувшины, как и погребение СК-2 № 33в, I - первой половиной II в. н.э.

В комплексе Л-1 № 20/1981 (рис. 23,1-5) вместе с кинжалом типа 1а найден сероглиняный кувшин с приземистым биконическим туловом и высоким цилиндрическим горлом. Кувшин такой же формы происходит из погребения СК-3 № 207, которое по стеклянному бальзамарию типа Isings 28b/AR 130.2 и лучковой подвязной фибуле серии I, варианта 3 ранее мы датировали второй половиной I началом II в. н.э. [Лимберис, Марченко, 2003, c. 114,182 , pис. 31 , № 85 ; Marčenko, Limberis, 2008, S. 388, Taf. 168, Kat.-Nr. 161]. Принимая во внимание общепринятую широкую датировку фибул 3 варианта [Кропотов, 2010, с. 75], дату комплекса СК-3 № 207 (см. также датировку погребения Л-1 № 364), скорее всего, следует сузить до начала II в. н.э., а комплекс Л-1 № 20/1981 датировать первой половиной - серединой II в. н.э.

В погребениях СК-2 № 326в (рис. 16,4-8) и СК-3 № 348 (рис. 7,6-12) вместе с кинжалами типа 1a были найдены кружки практически одинаковой конической формы. Комплекс СК-3 № 348 по лучковой подвязной фибуле серии I, варианта 2 и браслету с шишечками на концах датируется второй половиной I началом II в. н.э. [Лимберис, Марченко, 2020, c. 427 , pис. $2,17,18]$. Коническим кружкам в меотских погребениях сопутствуют фибулы типа «Авцисса» (СК-2 № 53в; ЕЛ-2 № 45/2013) с кнопкой на концеприемника и стеклянныебальзамарии (СК-3 № 216, СК-3 № 251) І в. н.э. [Marčenko, Limberis, 2008, S. 387, 388, Taf. 145, 169, Kat.-Nr. 140, 162]. Приведенные аналогии дают возможность датировать эти кружки, как и комплексы, в которых они встречаются, I - началом II в. н.э.

В комплексах Л-1 № 138/1981 с мечом типа 2a (рис. 21,5-9) и № 4/1983 с мечом типа 3a (рис. 22,1-4) присутствуют кружки с прямоугольной площадкой и выступом на ручке (см. также погребения СК-2 № 35в и Л-1 № 289/1981 с железными бритвами и кружками этой формы). Погребения с такими кружками могут быть датированы по совместным находкам неорнаментированных зеркал-подвесок с умбоном в центре (СК-2 № 2723, 3723; Л-1, № 271/11981), широкое распространение, которых в Прикубанье приходится на I в. н.э. [Марченко, 1996, с. 23-25, рис. 5].

В погребении СК-2 № 329в (рис. 15,6-11) с мечом типа 2а была найдена кружка с «мешковидным» туловом и отогнутым краем. Кружки этой формы встречены в комплексах Л-1 № 228/1981 с фибулой типа «Авцисса» и неорнаментированным зеркаломподвеской с умбоном в центре [Marčenko, Limberis, 2008, S. 387, 388, Taf. 127, Kat.-Nr. 115], и в ЕЛ-2 № 164/2013 - с таким же зеркалом. Это позволяет датировать погребение СК-2 № 329 І в. н.э.

В погребении СК-3 № 504 с мечом типа 1a (рис. 10,1-5) найдена кружка с овальным туловом и коротким горлом, выделенным в основании валиком. Аналогичная кружка из упоминавшегося уже комплекса СК-3 № 13 с мечом типа 26 сопровождалась лучковой подвязной фибулой I серии, варианта 3, которые часто встречаются с кружками этой формы (СК-2 № 57в, 58в; СК-3 № 12, 18, 203, 290, $439,373,428,494,512$ и др.). В других известных нам комплексах подобным кружкам сопутствовали фибулы I серии, варианта 2 (ЕЛ-2 № 103/2013; СК-3 № 233; СК-2 № 304в) и мелкие застежки с пластинчатой спинкой и завитком на конце приемника (СК-3 № 204, 203). Аналогии дают нам возможность датировать этот тип кружек, как и погребение СК-3 № 504, I - первой половиной II в. н.э.

В погребении Л-1 № 255/1981 (рис. 25,5-8) вместе с такой кружкой и кинжалом типа 2а присутствовала часть фибулы с выпуклой пластинчатой спинкой, которая может относиться к одному из двух типов - с завитком или кнопкой на конце приемника, - что также позволяет датировать данный комплекс I - первой половиной II в. н.э.

Кружки с округло-биконическим туловом и широким коротким цилиндрическим горлом, выделенным в основании узким выступом или желобком, происходят из погребений СК-2 № 2303 с кинжалом типа 1a (рис. 14,6-12), 
СК-3 № 255 с мечом типа 3a (рис. 8,8-12) и СК-3 № 266 с кинжалом типа 2а (рис. 5,7-14). Такие кружки широко представлены в меотских памятниках совместно с фибулами разных типов: пластинчатыми с завитком на конце приемника (Л-1 № 255/1981, СК-2 № 1453, СК-3 № 245, 317), лучковыми подвязными I серии, варианта 2 (СК-2 № 1343, СК-3 № 14), варианта 3 (СК-3 № 36, 211, 446, 452), сильнопрофилированными с бусинами и пластинчатой спинкой (СК-2 № 263, 2853, СК-3 № 2, $274,478)$. Опираясь на хронологию комплексов с этими кружками, мы можем широко датировать погребения СК-2 № 2303 и СК-3 № 255 I-II вв. н.э., возможно, и началом III в. н.э.

Уточнить дату погребения СК-3 № 266 (рис. 5,7-10) позволяет прямая стратиграфия. Его частично перекрывало погребение № 265, в котором были найдены стеклянные канфары типа Isings $28 \mathrm{a} / \mathrm{b}$ и чаша Zarte Rippenschale аметистового стекла (рис. 5,8,10). Данное погребение мы датировали второй - третьей четвертями I в. н.э. [Лимберис, Марченко, 2003, c. 109, 113, 186; Marčenko, Limberis, 2008, S. 388, Taf. 172, Kat.-Nr. 165]. В связи с этим хронология комплекса № 266 может быть ограничена последней четвертью I - началом III в. н.э.

В погребении СК-3 № 315 (рис. 9,9-11) вместе с мечом типа 3а найдена сероглиняная миска с сильно загнутым бортиком и слегка прогнутыми стенками, форма которой не характерна для меотской керамики, но часто встречается в центрально-предкавказских памятниках, где такие миски датируются I началом II в. н.э. [Абрамова, 1993, с. 142, рис. 55,3$]$.

Погребения Л-1 № 33/1980 (рис. 20,1-0) с мечом типа 1a (с ромбовидным в сечении перекрестием), Л-1 № 64/1980 (рис. 21,1-4), СК-2 № 3793 (рис. 15,1-5), СК-3 № 294 (рис. 6,1,2) с мечами типа 2а, Л-1 № 12/1980, Л-1 № 140/1981 (рис. 23,6-10), Л-1 № 174/1981 (рис. 24,1-3) с мечами и кинжалом типа 3а по сероглиняной меотской керамике можно датировать только широко - в пределах I-II вв. н.э.

В могильнике Воронежского городища № 3 в четырех погребениях (№ 7, 59, 172, 207), которые Н.В. Анфимов отнес к хронологической группе I-II вв. н.э., были найдены мечи типа 2 или 3 (определить форму рукояти по фотографиям из отчета нельзя) размерами от 83 до 100 см. Из погребения № 59 происходит также нож с кольцевым навершием [Анфимов, 1967, с. 36, 71; Анфимов, 1968, с. 67]. Такой же нож был встречен в комплексе СП № 98 I в. н.э. вместе с мечом с кольцевым навершием и сероглиняной керамикой этого времени [Лимберис, Марченко, 2019а, с. 207, рис. 1,15$]$. Еще один нож происходит из погребения СК-2 № 32в, которое было датировано нами I в. до н.э. [Лимберис, Марченко, 2020, c. 167]. Таким образом, ножи с кольцевым навершием в настоящее время нужно датировать в пределах І в. до н.э. - І в. н.э. Датировка же воронежского погребения № 59 может быть ограничена I в. н.э. Остальные погребения с мечами из Воронежского некрополя можно, вслед за Н.В. Анфимовым, датировать I-II вв. н.э.

В погребении № 2/1972 Пашковского могильника № 5 был найден меч типа 2 б. В отчете Н.В. Анфимова это погребение датировано I-II вв. н.э. [Анфимов, 1973, с. 14, рис. на стр. 17].

Катакомба № 1, исследованная на Пашковском могильнике № 2 (рис. 31), кроме меча типа 3б, содержала разнообразный и весьма информативный инвентарь, характерный для представителя меото-сарматского всаднического сословия: кинжал, наконечник копья, серп, удила с колесовидными псалиями, детали портупейного снаряжения, обувные железные пряжки и бронзовую фибулу с фигурной обмоткой. Фибула, которая является опорной находкой для датировки катакомбы, относится к варианту 4 серии I, широко распространенному в позднесарматское время на юге Восточной Европы [Амброз, 1966, с. 50, 51; Кропотов, 2010 , с. 77,80$]$. Анализ инвентаря позволил определить хронологический диапазон погребения в пределах конца II - cередины III в. н.э. [Лимберис, Марченко, 2015, с. 131-133, рис. 1, 2].

Этим же периодом по находке аналогичной фибулы датируется и погребение Л-1 № 27/1983 с мечом типа 2a (рис. 20,7-11).

В богатом катакомбном погребении СП № 161 (рис. 28) вместе с мечом типа 2а присутствовал многочисленный инвентарь: наконечник копья, удила с колесовидными псалиями, серп, бронзовые и серебряные пряжки и 
другие детали портупейного набора, серебряные гривна, браслет и проч. Уникальной находкой является железный умбон от щита, вероятно, представляющий собой модификацию западноевропейских типов таких изделий. Хронология комплекса, опирающаяся на совокупные датировки предметов инвентаря, определяется серединой III в. н.э. [Лимберис, Марченко, 2013, с. 106-113].

В погребении СП № 104, кроме меча типа 3a (рис. 3,5), не было другого инвентаря, поэтому придется удовлетвориться общей хронологией мечей без металлического навершия (I - середина III в. н.э.).

Определенной закономерности в положении мечей в погребении не прослеживается. Чаще меч располагался вдоль левой ноги или руки, реже справа. В ряде случаев меч лежал острием в сторону черепа (Л-1 № 227/1981 г., СК-2 № 270, УЛ-2 № 81/1938 г.). Иногда меч укладывался на туловище слева (СК-2 № 4833) или справа (СК-2 № 3793). В погребениях Л-1 № 64/1981 г. и СК-3 № 511 мечи были преднамеренно согнуты.

В погребениях меотских «всадников», которые сопровождались захоронениями лошадей или только наборами конской узды, в основном были встречены длинные мечи (СК-3 № 315, 338, 347, 511; Пашк.-2 № 1; СП № 161; СК-2 № 33в, 6133; ЕЛ-2 № 13), и лишь в захоронениях СК-3 № 504 и Л-1 № 138/1981 короткие. Кинжалы встречены, главным образом, в погребениях без лошадей или узды. Единственный комплекс, где сочетались меч (тип 1a) и кинжал (тип 3a) - это богатое погребение всадника СК-2 6133.

В некоторых погребениях рядом с рукоятями или клинками мечей лежали бусины из камня (Л-1 № 12/1981, СК-2 № 325в, Пашк.-2 № 1) или янтаря (Л-1 № 377/1981, СП № 161/2003), а также плоские костяные «ворворки» - округлые или прямоугольные (Л-1 № 33/1980, СК-2 № 35в, УЛ-2 № 81/1938).

Н.В. Анфимов отмечал, что меч из комплекса УЛ-2 № 81/1938 имел полусферическое костяное навершие, изготовленное из головки бедренной кости животного [Анфимов, 1951 , с. 197 , рис. 17,19$]$. Диаметр этого изделия - менее 2 см. Трудно представить навершие таких размеров. Очевидно, этот предмет использовался как деталь портупеи.
Дисковидная бусина (диаметр - 2,5 см) из меловой породы лежала на мече в катакомбе № 1 Пашковского могильника № 2 рядом с маленькой стеклянной бусиной и бронзовой портупейной пряжкой. Местоположение и размеры меловой бусины вряд ли позволяют рассматривать ее как навершие [Лимберис, Марченко, 2015, с. 132, рис. 2,1-3].

В погребении СП № 161/2003 крупная янтарная биконическая бусина (диаметр 4,5 см) была найдена под правым крылом таза (примерно у середины клинка меча) и, скорее всего, также имеет отношение к портупейному набору, связанному с мечом [Лимберис, Марченко, 2013, с. 112].

По мнению С.И. Безуглова, крупные бусины при длинных сарматских мечах служили деталями застежек портупейных ремней и фиксаторами ножен [Безуглов, 2000, с. 172, 177-178]. А.В. Иванов считает, что бусины, расположенные у клинков мечей, являлись навершиями, а нахождение их не у верхнего конца рукоятки свидетельствует о ритуальном умерщвлении меча [Иванов, 2008, с. 76-77]. В качестве аргумента своей гипотезы автор указывает на находку в погребении № 12 могильника городища № 1 хут. Ленина халцедоновой бусины [Иванов, 2008, с. 79]. Но малый диаметр (2,5 см) этой бусины вряд ли позволяет считать ее навершием. Местоположение бусины рядом с рукоятью меча, скорее, свидетельствует о том, что она имеет отношение к портупейному набору. Второй пример, который приводит А.В. Иванов, ссылаясь на находку в погребении СК-2 35в «каменного полусферического навершия» [Иванов, 2008, c. 78], также противоречит действительности. Здесь следует уточнить, что это не каменное и не полусферическое изделие, а костяная квадратная «ворворка» (рис. 13,2). Как уже говорилось, такие изделия встречаются не только с мечами без металлического навершия, но и с мечами с кольцевидными навершиями.

Если говорить о преднамеренном умерщвлении мечей, то в связи с этим обрядом стоит рассматривать лишь случаи положения в погребения преднамеренно согнутых клинков (Л-1 № 64/1980, СК-3 № 511). Что касается собственно наверший, пока нам известен всего один достоверный пример из погре- 
бения СК-3 № 511, где расколотое плоское халцедоновое навершие диаметром 5,9 см лежало у нижней части клинка (рис. 10,6,7).

В погребениях, сопровождавшихся бусинами и «ворворками» железные скобы на мечах отсутствовали. В таких случаях, отмеченных для сарматских мечей, С.И. Безуглов гипотетично допускает наличие на ножнах деревянных скоб [Безуглов, 2000, с. 178]. Наличие же металлических скоб было зафиксировано только в погребении СК-2 6133 (рис. 19,2,3). К деревянным ножнам меча на расстоянии 52 см от конца рукояти крепилась пластинчатая железная скоба. Вторая скоба, согнутая из узкой пластины с заостренными концами, была найдена под мечом, ближе к перекрестию [Лимберис, Марченко, 2012, c. 147,152 , рис. $4,2,3]$. В погребении УЛ-2 № 81/1938 на поясничных позвонках человека был найден железный крючок, который, по предположению Н.В. Анфимова, мог служить для подвешивания меча [Анфимов, 1951, с. 197].

Хронологическая атрибуция погребений с мечами без металлического навершия показывает, что это клинковое оружие появля- ется у меотов правобережья Кубани в начале I в. н.э. и бытует вплоть до середины III в. н.э. Причем к третьему столетию пока можно отнести всего 3 экземпляра. Как и в сарматских погребениях Нижнего Поволжья, в меотских комплексах мечи и кинжалы всех типов синхронны [Кривошеев, 2007, с. 66, 67]. Но, в отличие от сарматских памятников, где не отмечается преобладание какого-то одного типа мечей, у меотов явное преимущество имели клинки типа 2 (табл. 1).

Как уже отмечалось, мечи без металлического навершия у сармат появляются значительно раньше, чем у меотов, - во II-I вв. до н.э. Однако меотские воины заимствовали этот вид оружия у кочевников лишь в начале I в. н.э. Меоты быстро наладили собственное производство мечей по сарматским образцам, так как имели собственную высокоразвитую металлообрабатывающую базу, и могли обеспечивать не только свои потребности, но и поставлять оружие кочевникам. Меч с бронзовым перекрестием из сарматского погребения СК-2 № 6133, по всей видимости, имеет восточное происхождение. 
N.Yu. Limberis, I.I. Marchenko, A.V. Kondratenko. Swords and Daggers Without a Metal Pommel

\section{ИЛЛЮСТРАЦИИ}

Таблица 1. Мечи и кинжалы без металлического навершия (размерные характеристики и датировка)

Table 1. Swords and daggers without metal pommel (dimensional characteristics and dating)

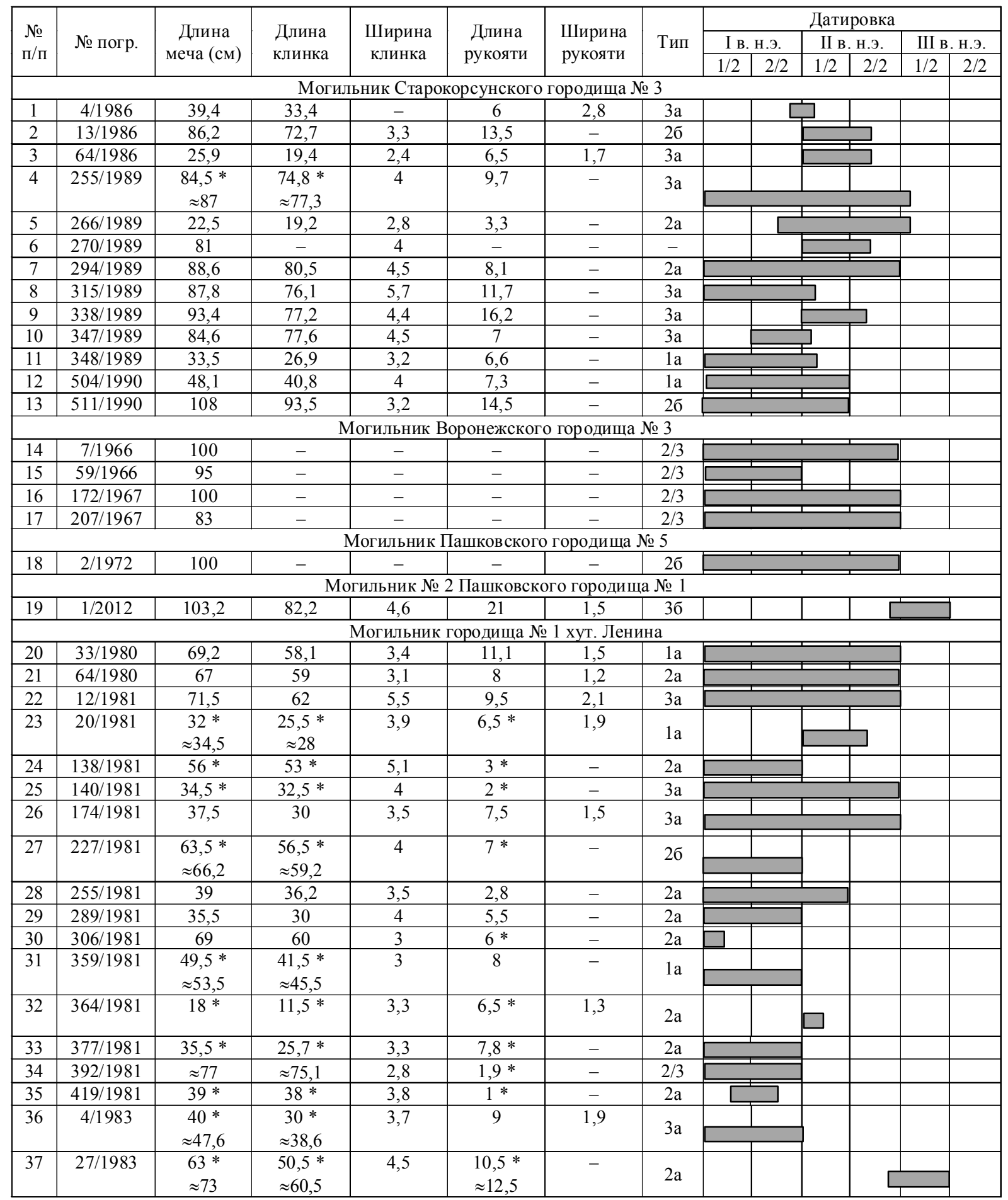

Примечание. * - сохранившаяся длина; $\approx-$ восстановленная длина.

Note. ${ }^{*}$ - preserved length; $\approx$ - recovered length. 


\section{Окончание таблицы 1}

End of Table 1

\begin{tabular}{|c|c|c|c|c|c|c|c|c|c|c|c|c|c|}
\hline \multirow{3}{*}{$\begin{array}{l}\text { № } \\
\text { П/ח }\end{array}$} & \multirow{3}{*}{ № погр. } & \multirow{3}{*}{$\begin{array}{c}\text { Длина } \\
\text { меча (см) }\end{array}$} & \multirow{3}{*}{$\begin{array}{l}\text { Длина } \\
\text { клинка }\end{array}$} & \multirow{3}{*}{$\begin{array}{c}\text { Ширина } \\
\text { клинка }\end{array}$} & \multirow{3}{*}{$\begin{array}{c}\text { Длина } \\
\text { рукояти }\end{array}$} & \multirow{3}{*}{$\begin{array}{l}\text { Ширина } \\
\text { рукояти }\end{array}$} & \multirow{3}{*}{ Тип } & \multicolumn{6}{|c|}{ Датировка } \\
\hline & & & & & & & & \multicolumn{2}{|c|}{ I в. н.э. } & \multicolumn{2}{|c|}{ II в. н.э. } & \multicolumn{2}{|c|}{ III в. н.Э. } \\
\hline & & & & & & & & $1 / 2$ & $2 / 2$ & $1 / 2$ & $2 / 2$ & & $2 / 2$ \\
\hline \multicolumn{14}{|c|}{ Могильник городища «Спорное» } \\
\hline 38 & $104 / 2003$ & $84 *$ & $78,8 *$ & 5,2 & $6,8 *$ & 2,4 & $3 a$ & & & & & & \\
\hline & & $\approx 90$ & $\approx 84,8$ & & & & & & & & & & \\
\hline 39 & $161 / 2003$ & 95,4 & 82 & 4,4 & 13,4 & 2,6 & $2 \mathrm{a}$ & & & & & ᄃ & \\
\hline \multicolumn{14}{|c|}{ Могильник Старокорсунского городища № 2} \\
\hline 40 & $33 \mathrm{~B}$ & $\begin{array}{l}74,6^{*} \\
\approx 76,8\end{array}$ & $\begin{array}{l}66,6^{*} \\
\approx 68,8\end{array}$ & 3,8 & 8 & 1,6 & $2 \mathrm{a}$ & & & & & & \\
\hline 41 & $35 \mathrm{~B}$ & 63 & 52,5 & 2,8 & 10,5 & 1,35 & $2 \mathrm{a}$ & & & & & & \\
\hline 42 & $325 \mathrm{~B}$ & 73,5 & 66,2 & 3 & 7,3 & 1,6 & $2 \mathrm{a}$ & & & & & & \\
\hline 43 & $326 \mathrm{~B}$ & 39,6 & 30,5 & 3,3 & 9,1 & 1,0 & $1 \mathrm{a}$ & & & & & & \\
\hline 44 & $329 \mathrm{~B}$ & 67 & 56,5 & 3 & 10,5 & - & $2 \mathrm{a}$ & & & & & & \\
\hline 45 & 2183 & 32,2 & 25,1 & 3,1 & 7,1 & - & $3 a$ & & & & & & \\
\hline 46 & 2303 & 31 & 23,6 & 3 & 7,4 & - & $1 \mathrm{a}$ & & & & & & \\
\hline 47 & 3793 & $73^{*}$ & 67 & 3,8 & $6 *$ & - & $2 \mathrm{a}$ & & & & & & \\
\hline 48 & 4823 & 61,4 & 51,8 & 3,6 & 9,6 & - & $2 \mathrm{a}$ & & & & & & \\
\hline 49 & 5543 & 28,7 & 25,6 & 3 & $3,1 *$ & - & $2 \mathrm{a}$ & & & & & & \\
\hline 50 & 6133 & 98,6 & 85,8 & 4,4 & 12,8 & 2,8 & $1 \mathrm{a}$ & & & & & & \\
\hline \multicolumn{14}{|c|}{ Могильник Елизаветинского городиша № 2} \\
\hline 51 & $31 / 1978$ & $\approx 80$ & $\approx 65$ & $\approx 5,1$ & $\approx 11$ & - & $1 \mathrm{a}$ & & & & & & \\
\hline 52 & $93 / 1978$ & 99,3 & 86,8 & 3,5 & 12,5 & - & $1 \mathrm{a}$ & & & & & & \\
\hline 53 & $13 / 2013$ & 98 & 79 & 4 & 19 & - & 36 & & & & & & \\
\hline 54 & $140 / 2013$ & 91 & 74 & 4 & 17 & - & 36 & 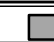 & & & & & \\
\hline \multicolumn{14}{|c|}{ Могильник Усть-Лабинского городища № 2} \\
\hline 55 & $13 / 1931$ & - & - & - & - & - & $2 / 3$ & & & & & & \\
\hline 56 & $81 / 1938$ & 76 & 60 & 4 & 16 & - & 36 & & & & & & \\
\hline 57 & $2 / 1944$ & - & - & - & - & - & $2 / 3$ & & & & & & \\
\hline
\end{tabular}




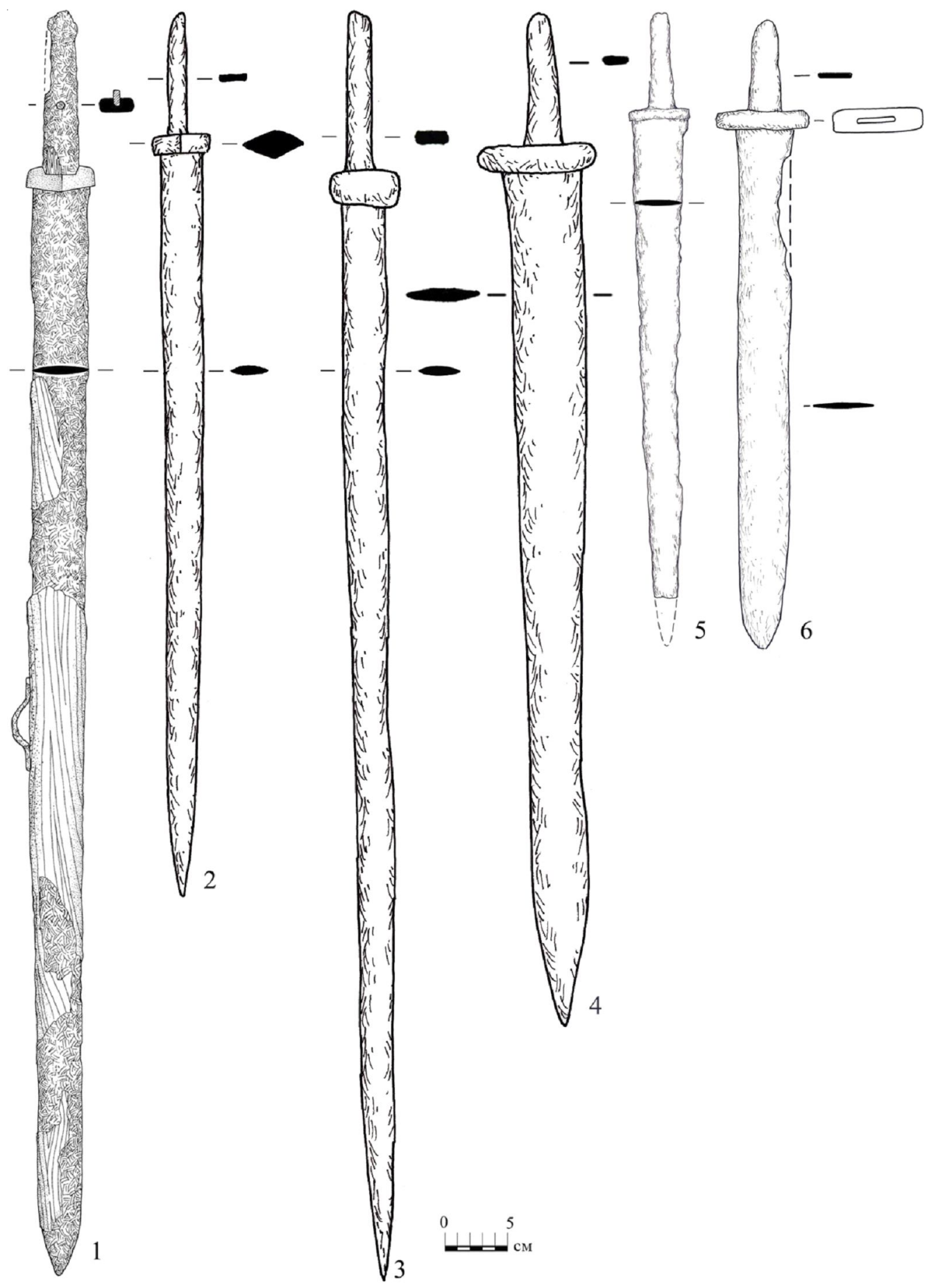

Рис. 1. Меотские мечи без металлического навершия (тип 1):

1 - СК-2 № 6133; 2 - Л-1 № 33/1980; 3 - ЕЛ-2 № 93/1978; 4 - ЕЛ-2 № 31/1978; 5 - Л-1 № 359/1981; 6 - СК-3 № 504

Fig. 1. Maeotian swords without the metal top (type 1):

1 - Starokorsunskaya-2, No. 6133; 2 - Lenin-1, No. 33/1980; 3 - Elisavetinskaya-2, No. 93/1978; 4 - Elisavetinskaya-2, No. 31/1978; 5 - Lenin-1, No. 359/1981; 6 - Starokorsunskaya-3, No. 504 
Н.Ю. Лимберис, И.И. Марченко, А.В. Кондратенко. Мечи и кинжалы без металлического навершия
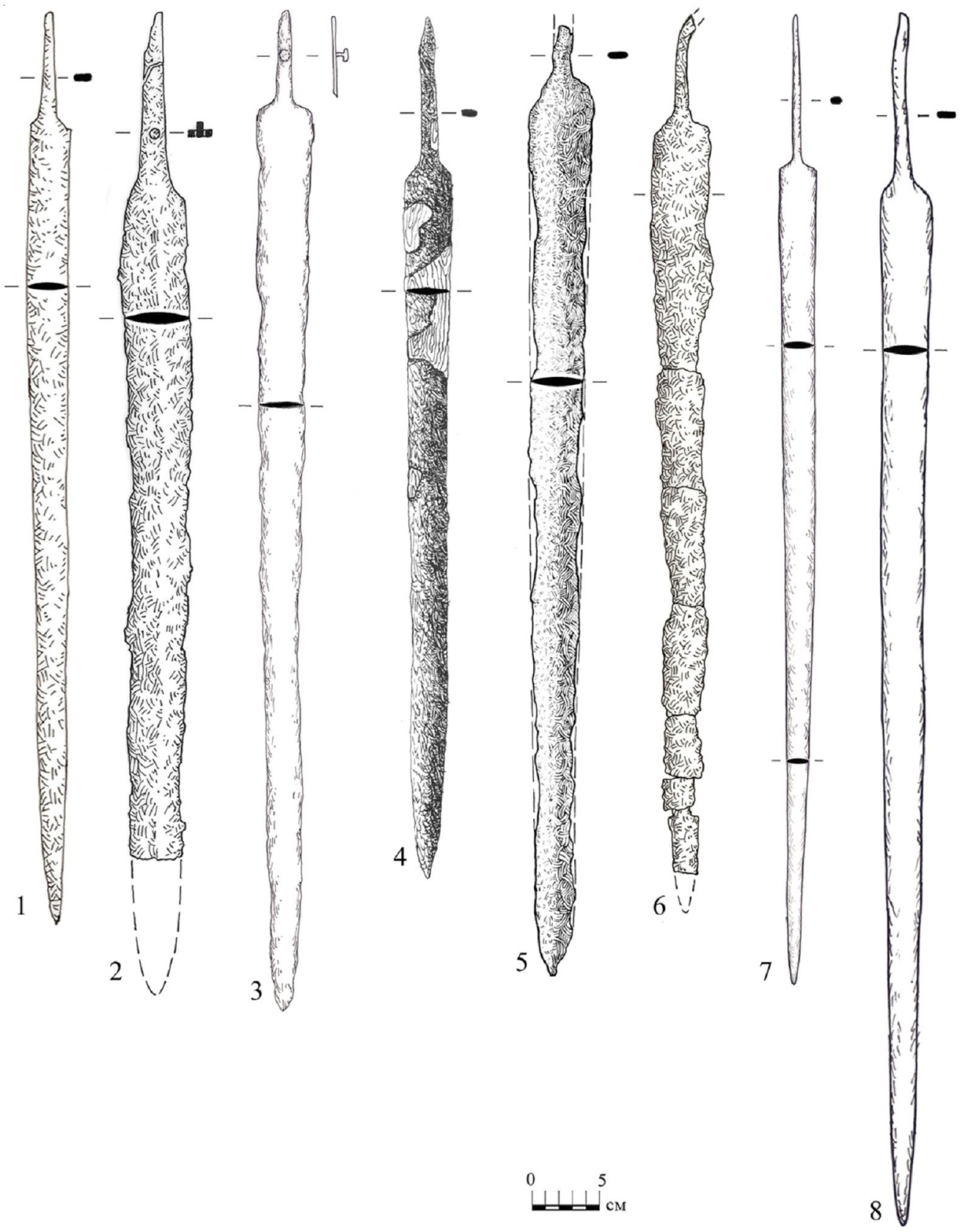

Рис. 2. Меотские мечи без металлического навершия (тип 2)

Вариант «а»: 1 - Л-1 № 64/1980; 2 - Л-1 № 27/1983; 3 - СК-3 № 294; 4 - СК-2 № 35в; 5 - СК-2 № 3793. Вариант «б»: 6 - Л-1 № 227; 7 - СК-3 № 13; 8 - СК-3 № 511

Fig. 2. Maeotian swords without the metal top (type 2)

Variant “a”: 1 - Lenin-1, No. 64/1980; 2 - Lenin-1, No. 27/1983; 3 - Starokorsunskaya-3, No. 294;

4 - Starokorsunskaya-2, No. 35в; 5 - Starokorsunskaya-2, No. 3793.

Variant " $\sigma$ ": 6 - Lenin-1, No. 227; 7 - Starokorsunskaya-3, No. 13; 8 - Starokorsunskaya-3, No. 511 
N.Yu. Limberis, I.I. Marchenko, A.V. Kondratenko. Swords and Daggers Without a Metal Pommel
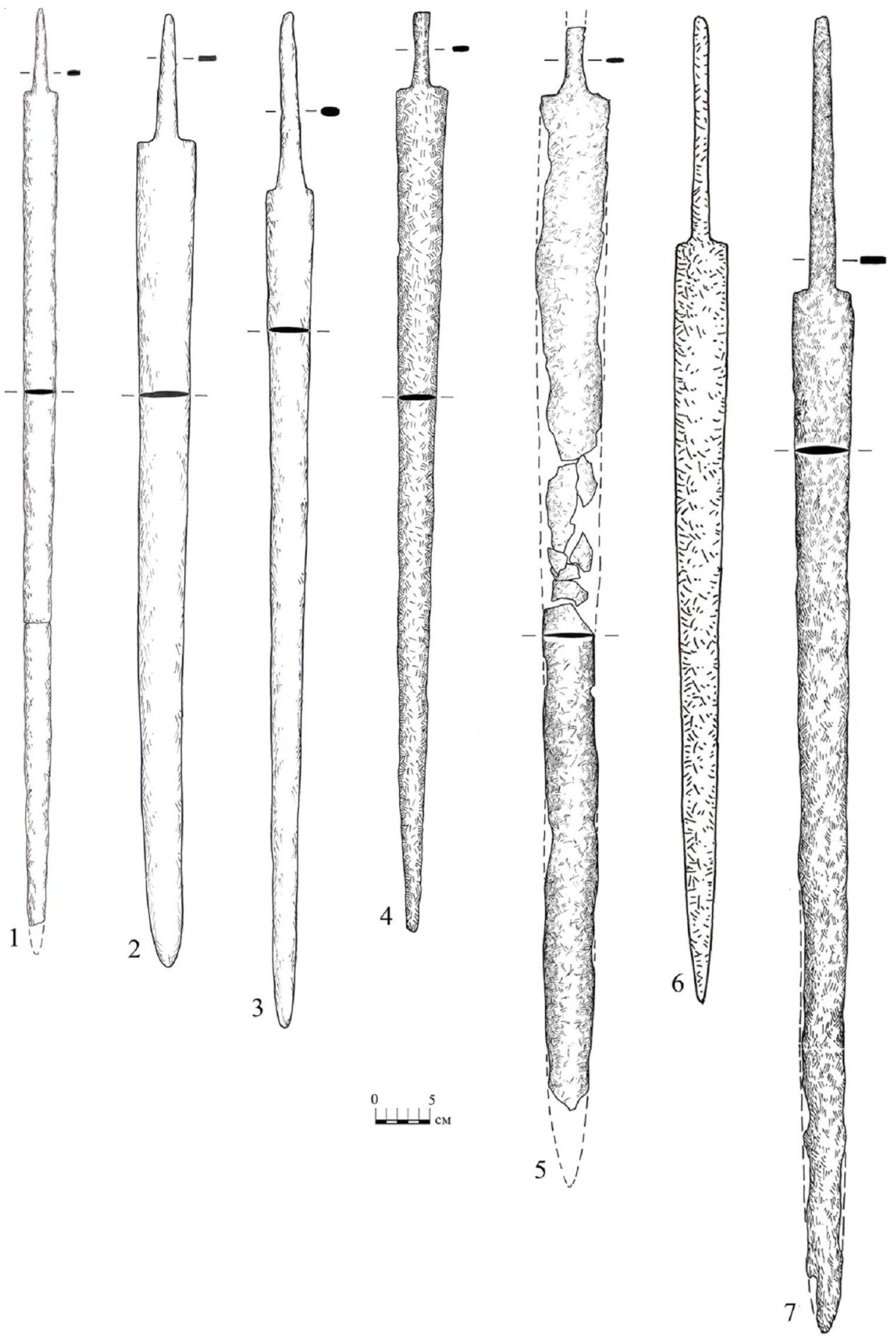

Рис. 3. Меотские мечи без металлического навершия (тип 3)

Вариант «а»: 1 - СК-3 № 255; 2 - СК-3 № 315; 3 - СК-3 № 338; 4 - СК-3 № 347; 5 - СП № 104. Вариант «б»: 6 - УЛ-2 № 81/1938; 7 - Пашк.-2 № 1

Fig. 3. Maeotian swords without the metal top (type 3)

Variant " $a$ ": 1 - Starokorsunskaya-3, No. 255; 2 - Starokorsunskaya-3, No. 315; 3 - Starokorsunskaya-3, No. 338; 4 - Starokorsunskaya-3, No. 347; 5 - Spornoye, No. 104.

Variant "б": 6 - Us't-Labinsk-2, No. 81/1938; 7 - Pashkovskaya-2, No. 1 
Н.Ю. Лимберис, И.И. Марченко, А.В. Кондратенко. Мечи и кинжалы без металлического навершия
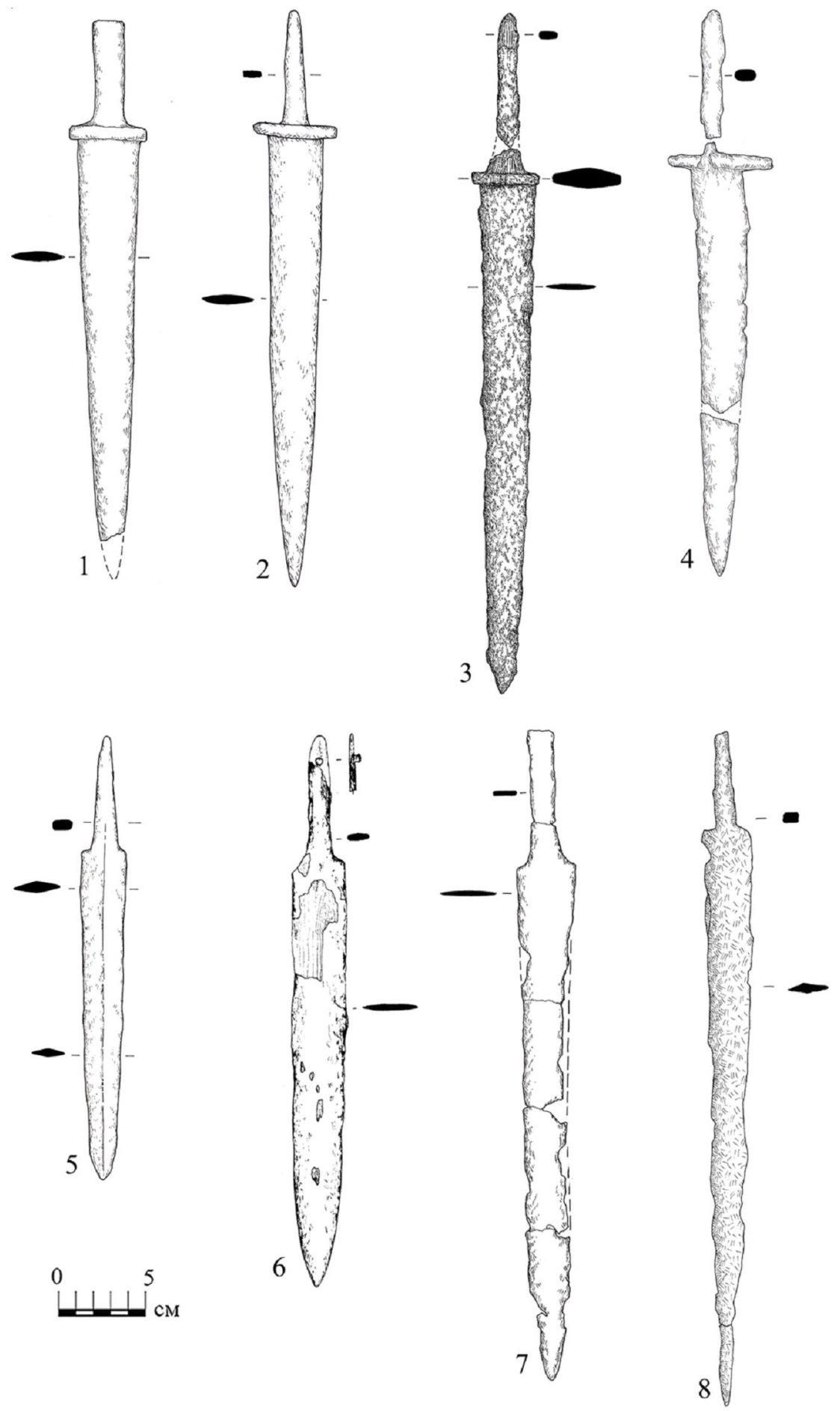

Рис. 4. Меотские кинжалы без металлического навершия

Tun 1: 1 - Л-1 № 20/1980; 2 - СК-3 № 348; 3 - СК-2 № 326в; 4 - СК-2 2303. Tun 3: 5 - СК-3 № 64; 6 - СК-2 2183; 7 - Л-1 № 184/1981; 8 - СК-3 № 4

Fig. 4. Maeotian daggers without the metal top

Type 1: 1 - Lenin-1, No. 20/1980; 2 - Starokorsunskaya-3, No. 348;

3 - Starokorsunskaya-2, No. 326в; 4 - Starokorsunskaya-2, No. 2303.

Type 3: 5 - Starokorsunskaya-3, No. 64; 6 - Starokorsunskaya-2, No. 2183;

7 - Lenin-1, No. 184/1981; 8 - Starokorsunskaya-3, No. 4 
N.Yu. Limberis, I.I. Marchenko, A.V. Kondratenko. Swords and Daggers Without a Metal Pommel
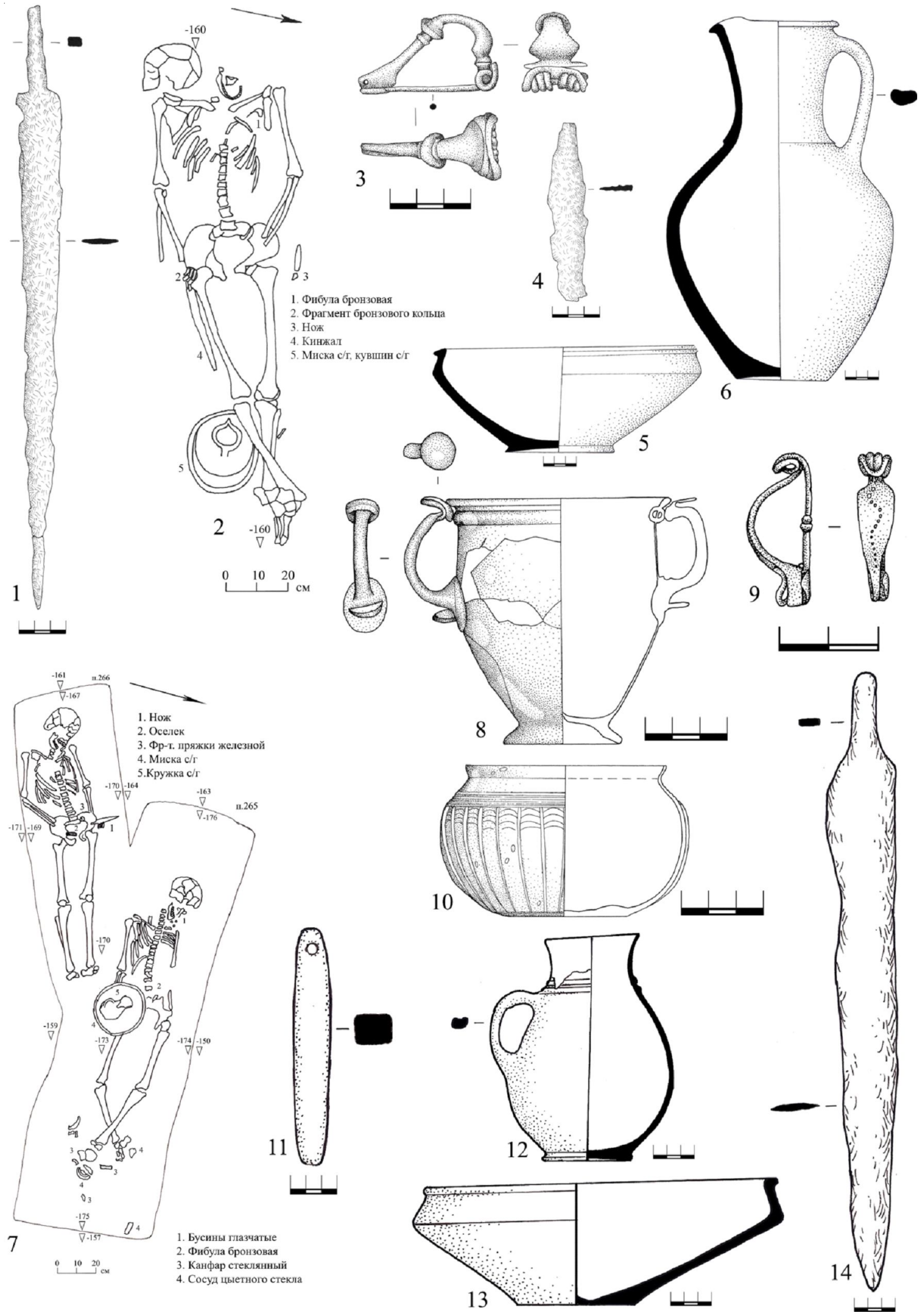

Рис. 5. Могильник Старокорсунского городища № 3:

1-6 - погребение № 4; 7-10 - погребение № 265; 11-14 погребение № 266

Fig. 5. Burial ground of the Starokorsunskaya settlement No. 3:

1-6 - burial No. 4; 7-10 - burial No. 265; 11-14 - burial No. 266 


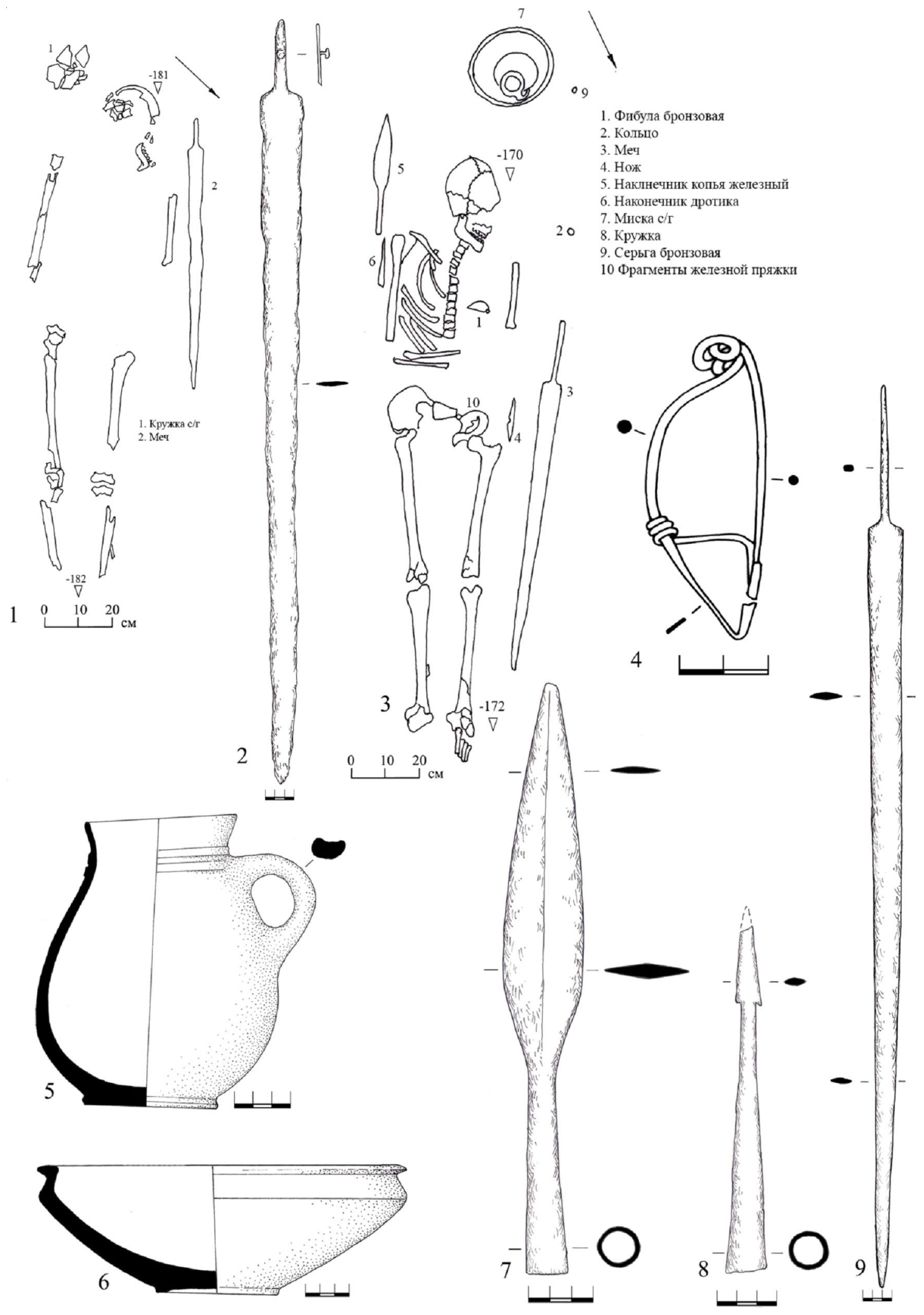

Рис. 6. Могильник Старокорсунского городища № 3:

1-2 - погребение № 294; 3-9- погребение № 13

Fig. 6. Burial ground of the Starokorsunskaya settlement No. 3:

1-2 - burial No. 294; 3-9 - burial No. 13 


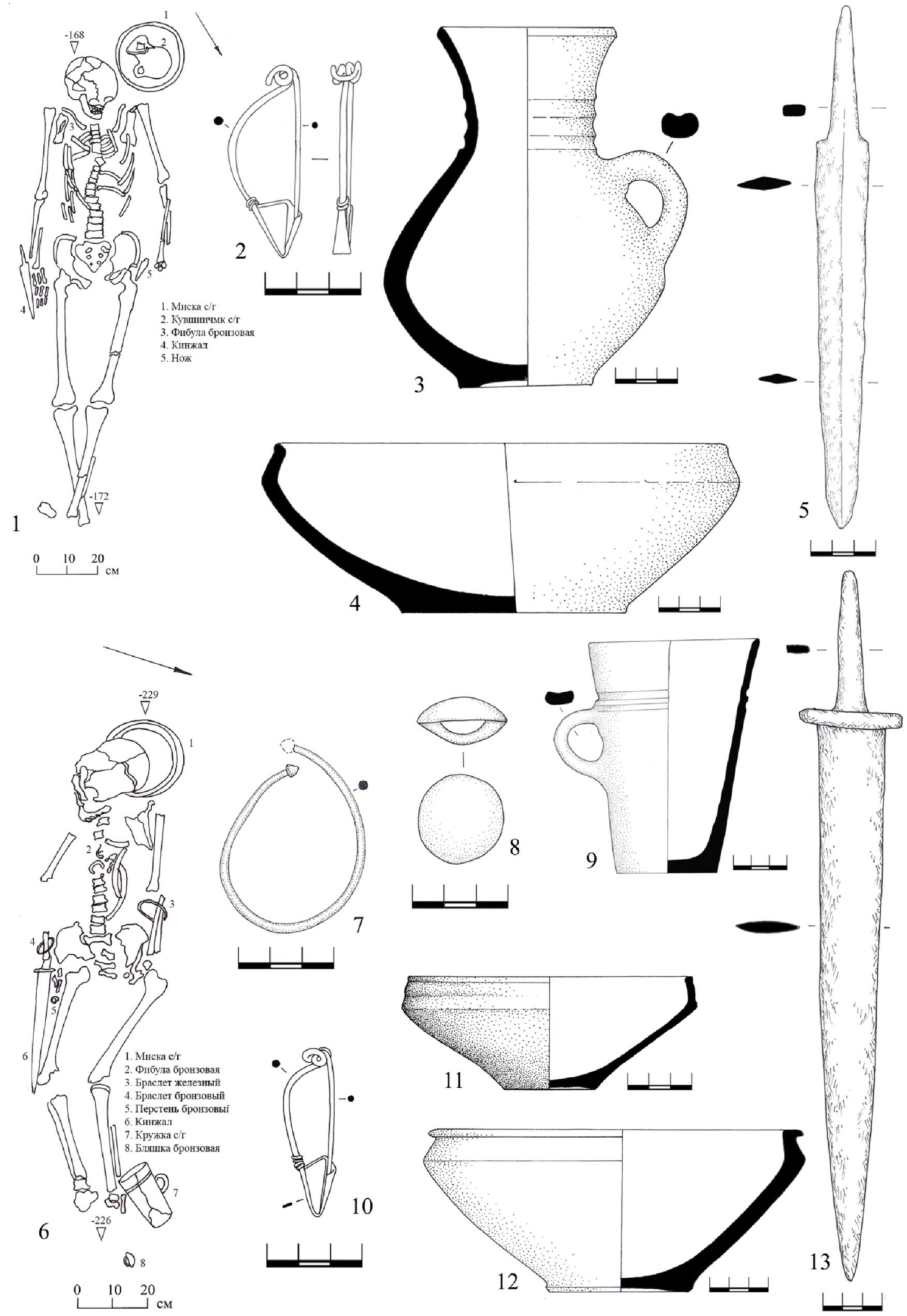

Рис. 7. Могильник Старокорсунского городища № 3:

1-5 - погребение № 64; 6-13 - погребение № 348

Fig. 7. Burial ground of the Starokorsunskaya settlement No. 3:

1-5 - burial No. 64; 6-13 - burial No. 348 


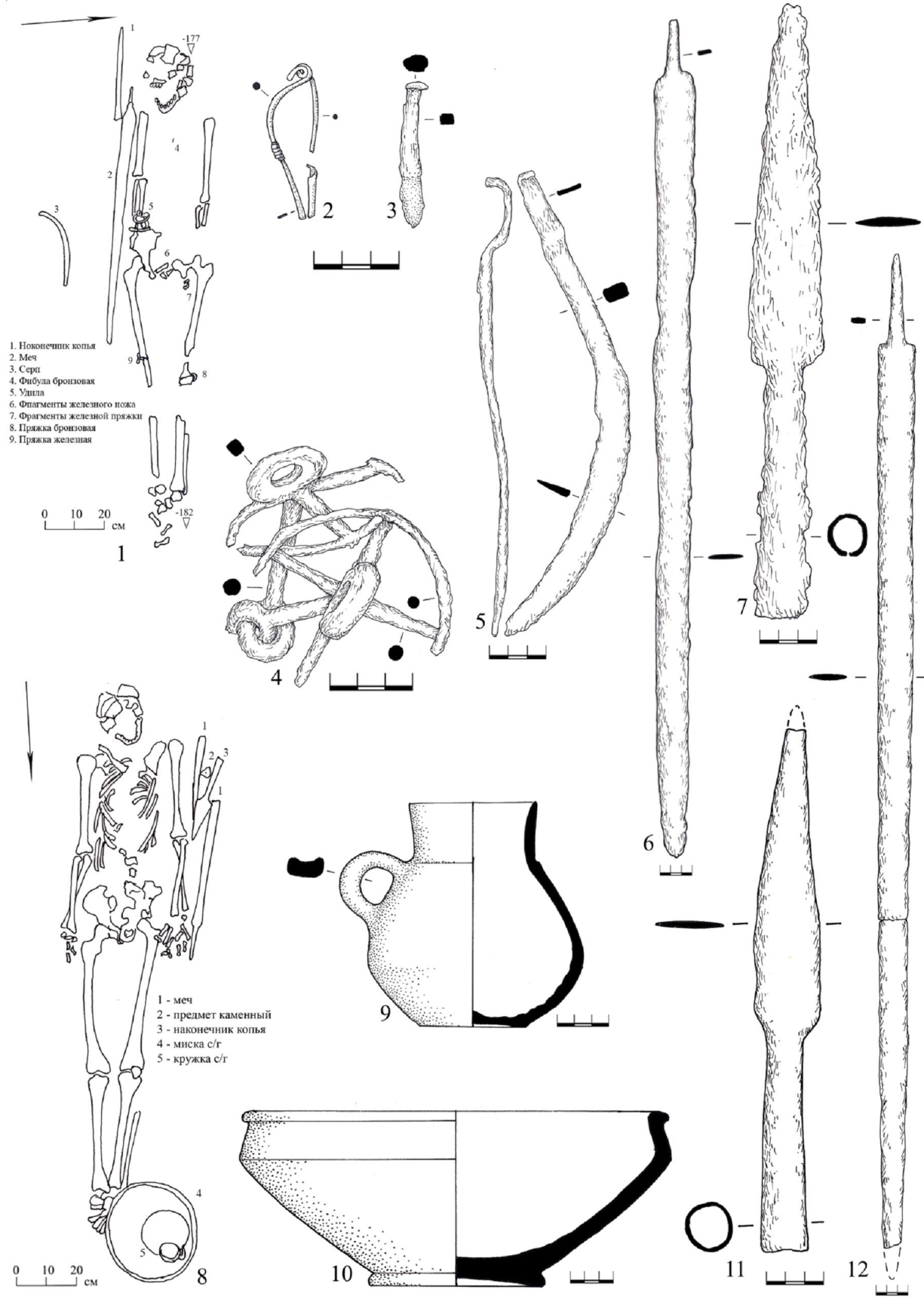

Рис. 8. Могильник Старокорсунского городища № 3:

1-7 - погребение № 270; 8-12 - погребение № 255

Fig. 8. Burial ground of the Starokorsunskaya settlement No. 3:

1-7 - burial No. $270 ; 8-12$ - burial No. 255 
N.Yu. Limberis, I.I. Marchenko, A.V. Kondratenko. Swords and Daggers Without a Metal Pommel

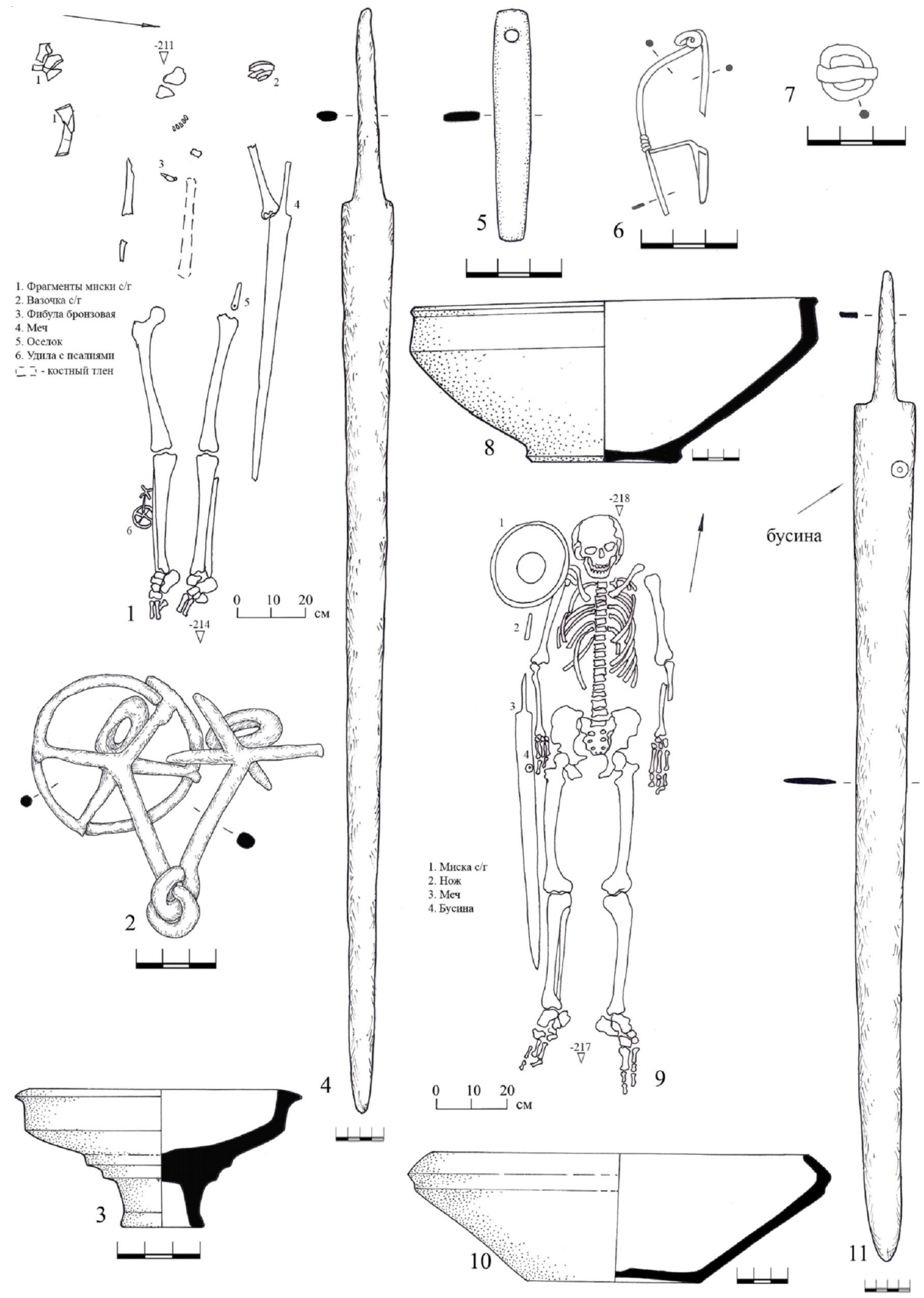

Рис. 9. Могильник Старокорсунского городища № 3:

1-8- погребение № 338; 9-11- погребение № 315

Fig. 9. Burial ground of the Starokorsunskaya settlement No. 3:

1-8 - burial No. 338; 9-11 - burial No. 315 


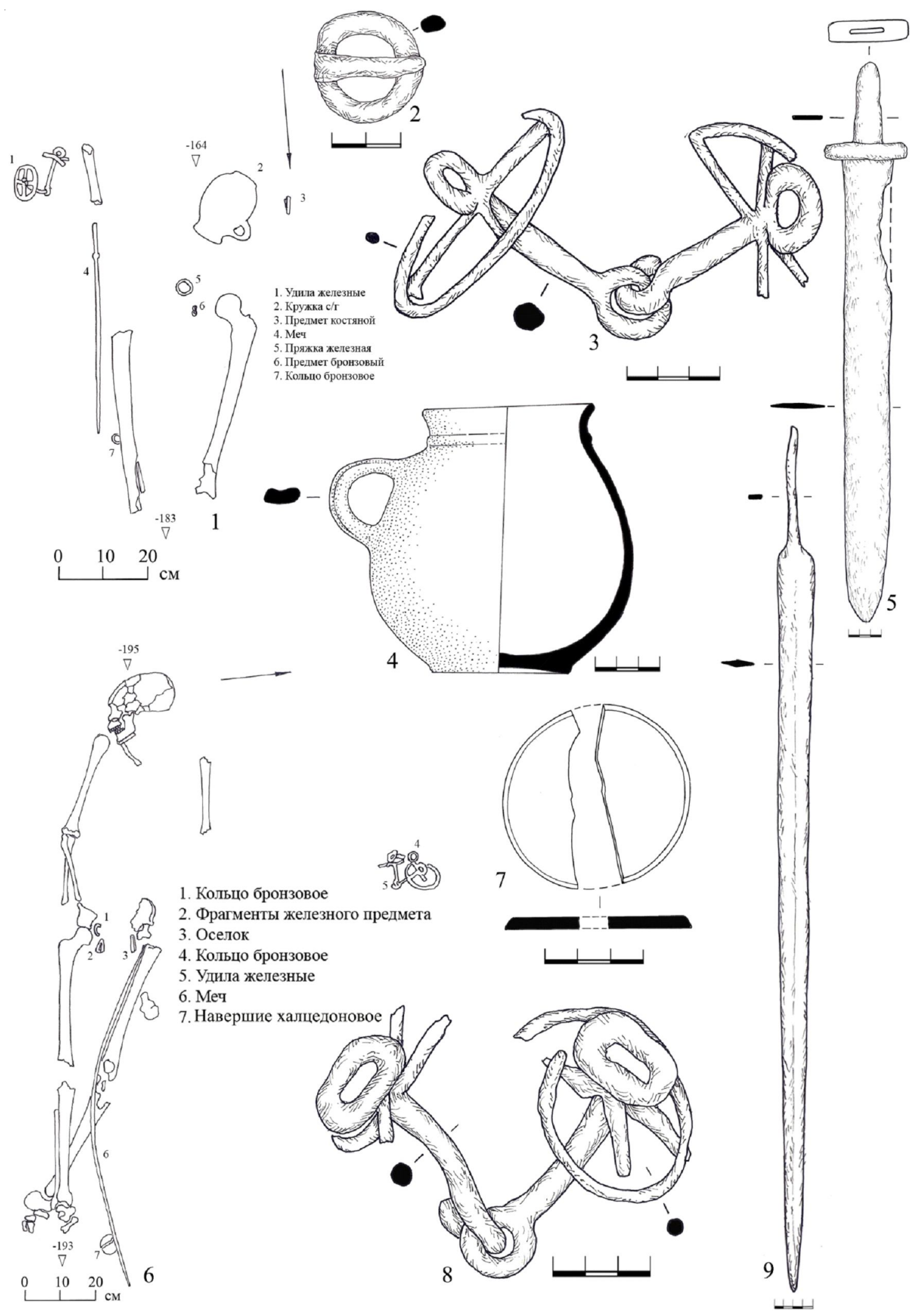

Рис. 10. Могильник Старокорсунского городища № 3:

1-5 - погребение № 504; 6-9 - погребение № 511

Fig. 10. Burial ground of the Starokorsunskaya settlement No. 3:

1-5 - burial No. 504; 6-9- burial No. 511 


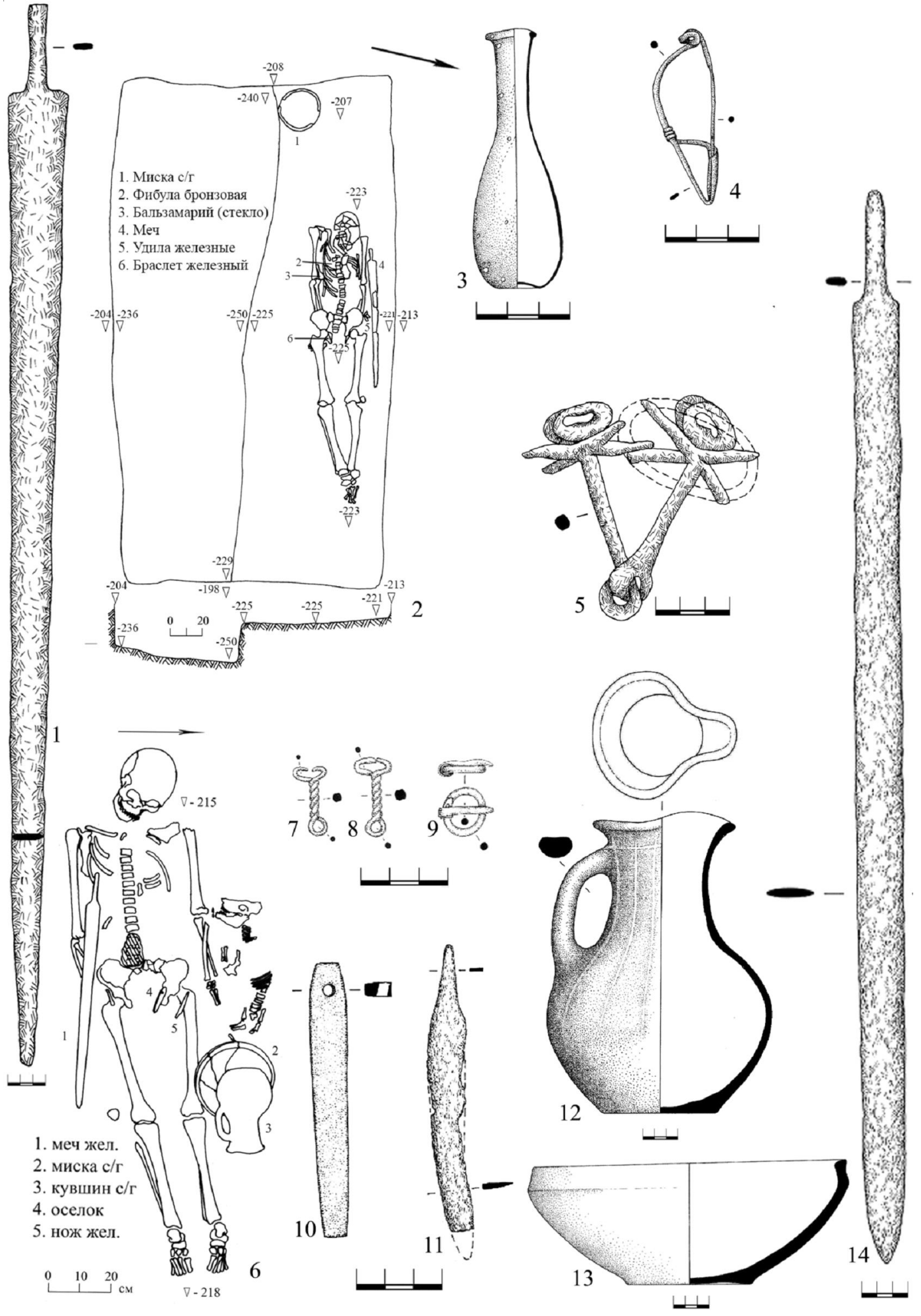

Рис. 11:

1-5 - Могильник Старокорсунского городища № 3, погребение № 347; 6-14 - Могильник Старокорсунского городища № 2, погребение № 325в

Fig. 11:

1-5 - Burial ground of the Starokorsunskaya settlement No. 3, burial No. 347; 6-14 - Burial ground of the Starokorsunskaya settlement No. 2, burial No. 325в 


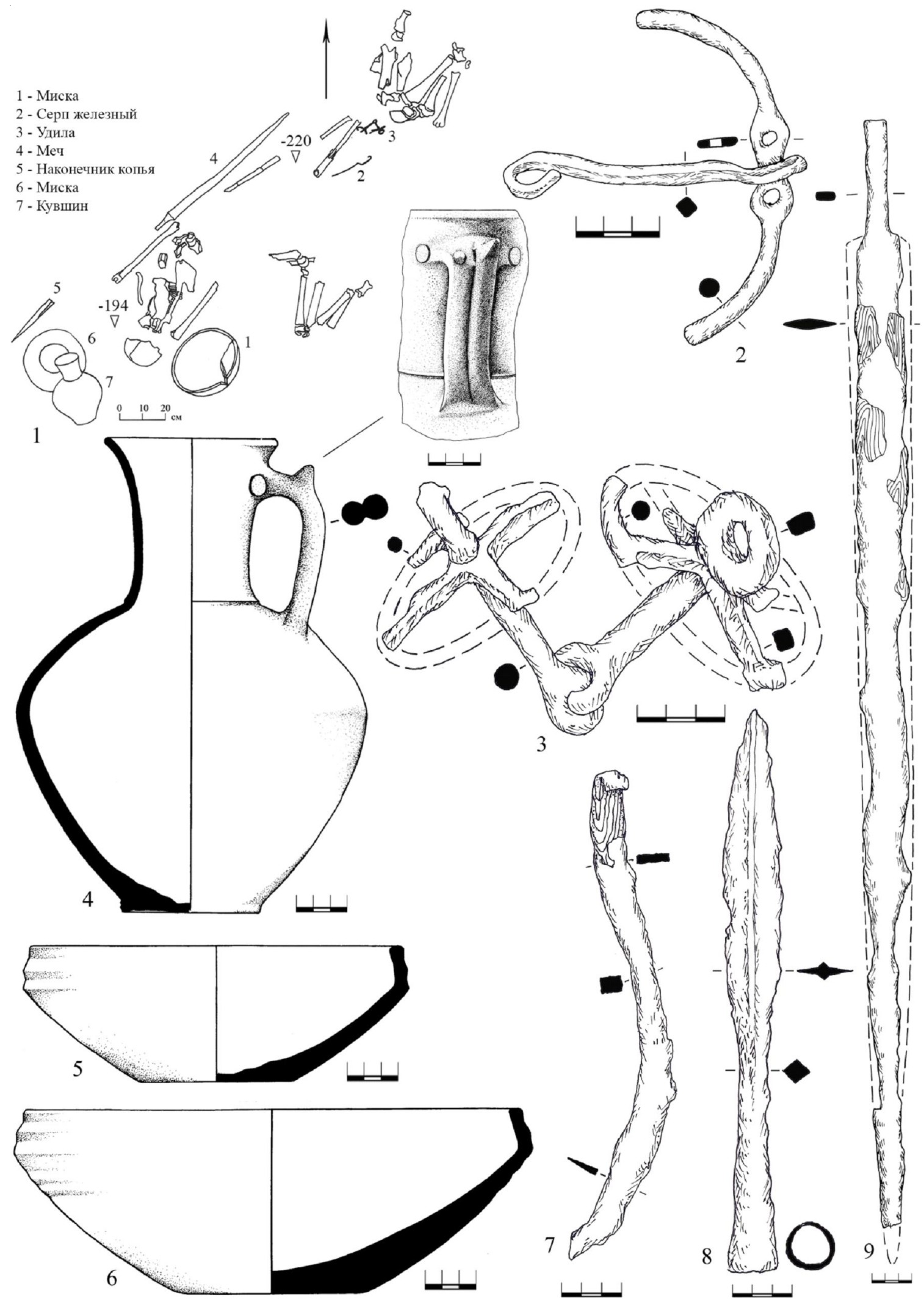

Рис. 12. Могильник Старокорсунского городища № 2, погребение № 33в

Fig. 12. Burial ground of the Starokorsunskaya settlement No. 2, burial No. 33в 

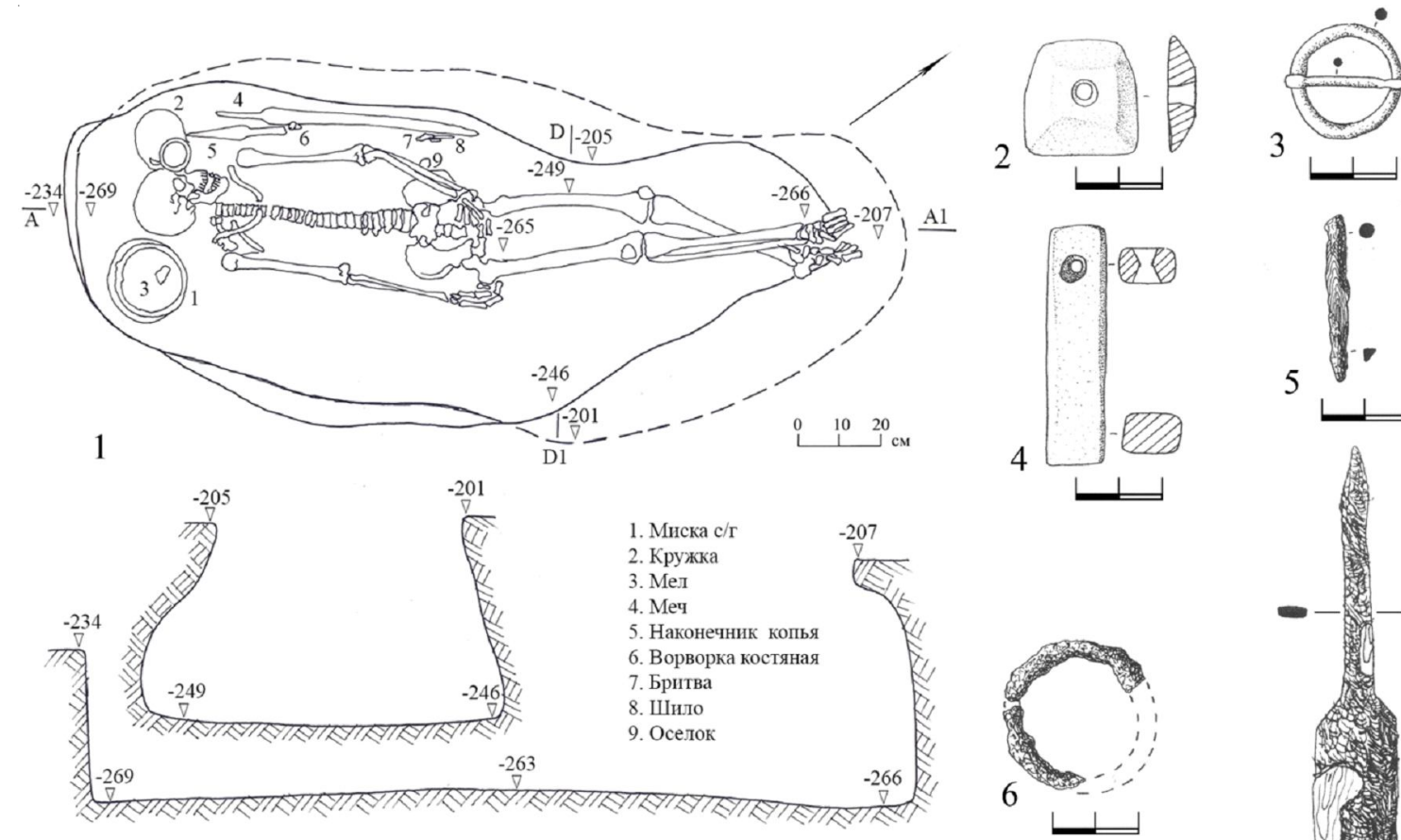

3
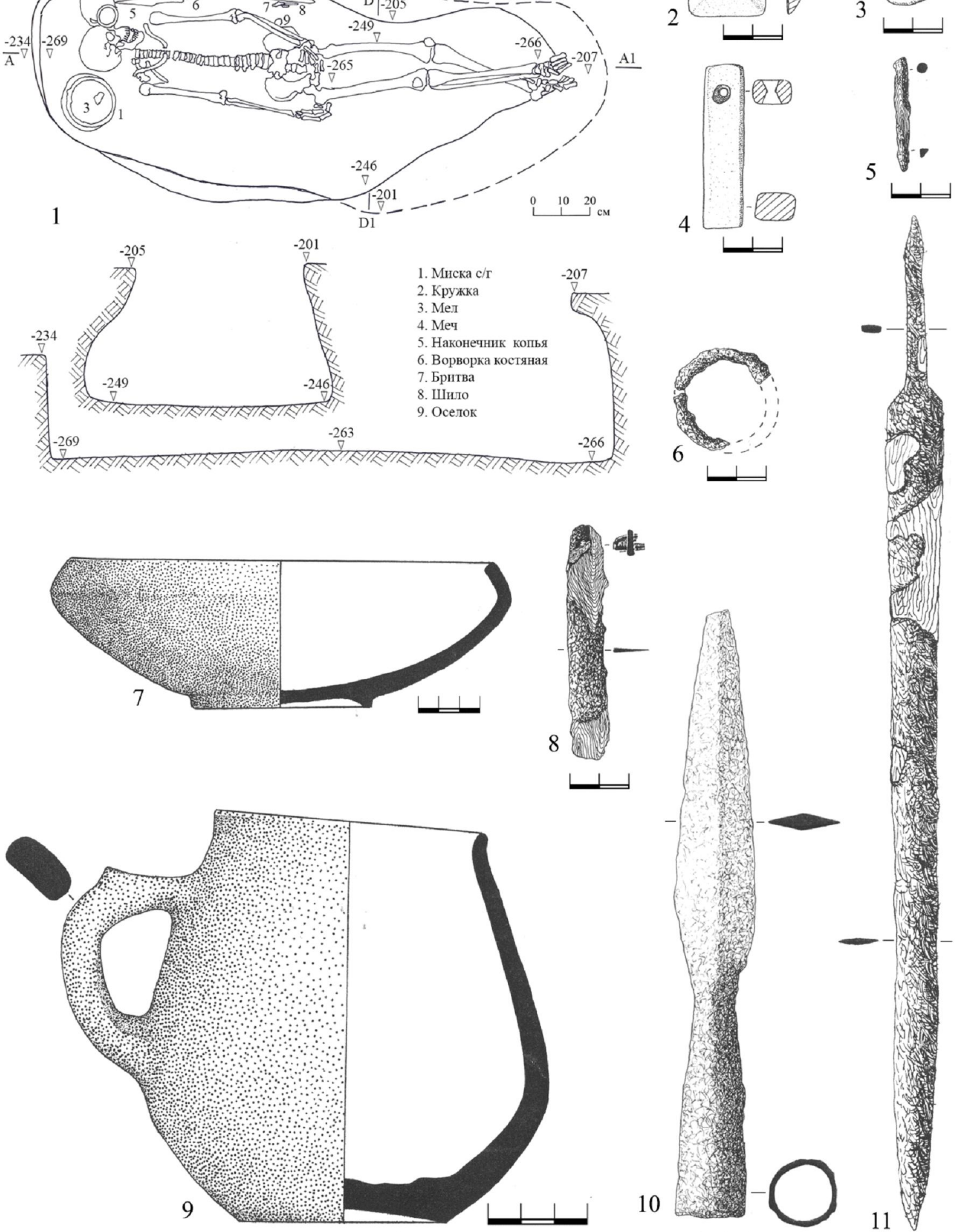

10
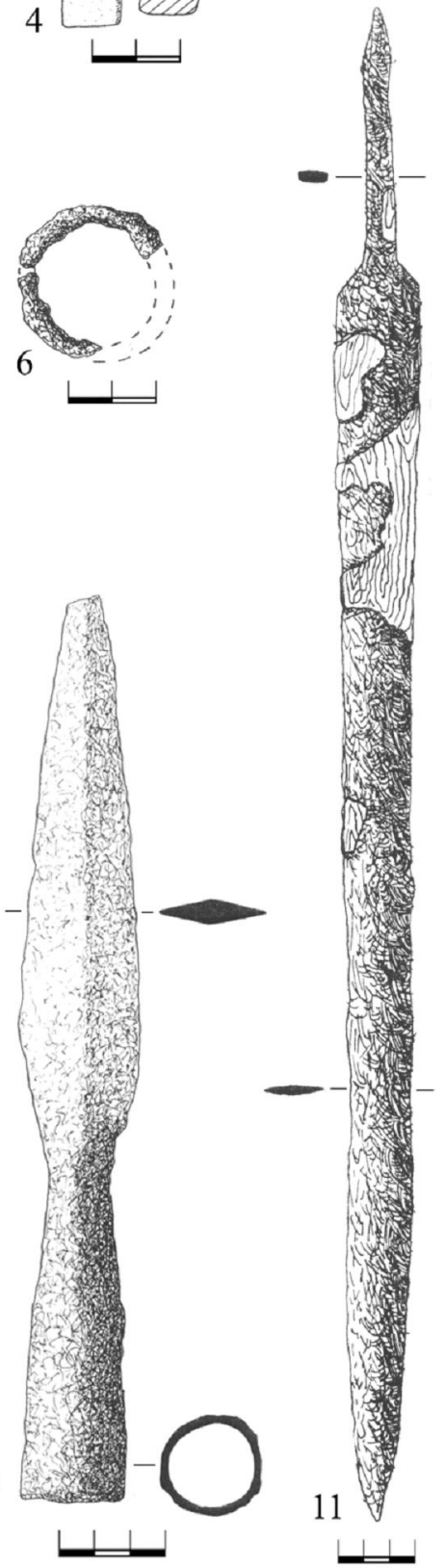

11 列

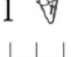

Рис. 13. Могильник Старокорсунского городища № 2, погребение № 35в

Fig. 13. Burial ground of the Starokorsunskaya settlement No. 2, burial No. 35в 


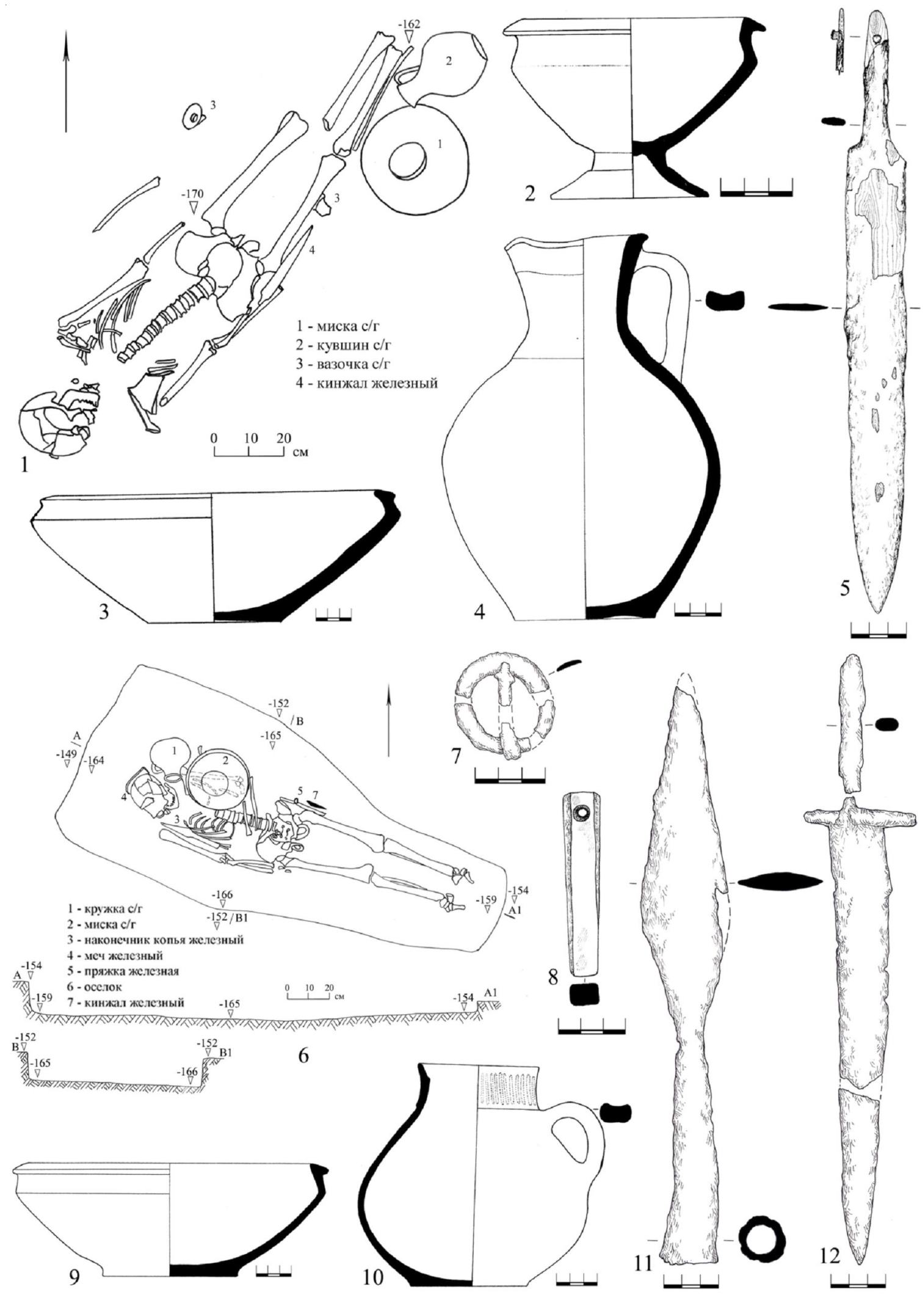

Рис. 14. Могильник Старокорсунского городища № 2:

1-5 - погребение № 2183; 6-12 - погребение № 2303

Fig. 14. Burial ground of the Starokorsunskaya settlement No. 2:

1-5 - burial No. 2183; 6-12 - burial No. 2303 
N.Yu. Limberis, I.I. Marchenko, A.V. Kondratenko. Swords and Daggers Without a Metal Pommel
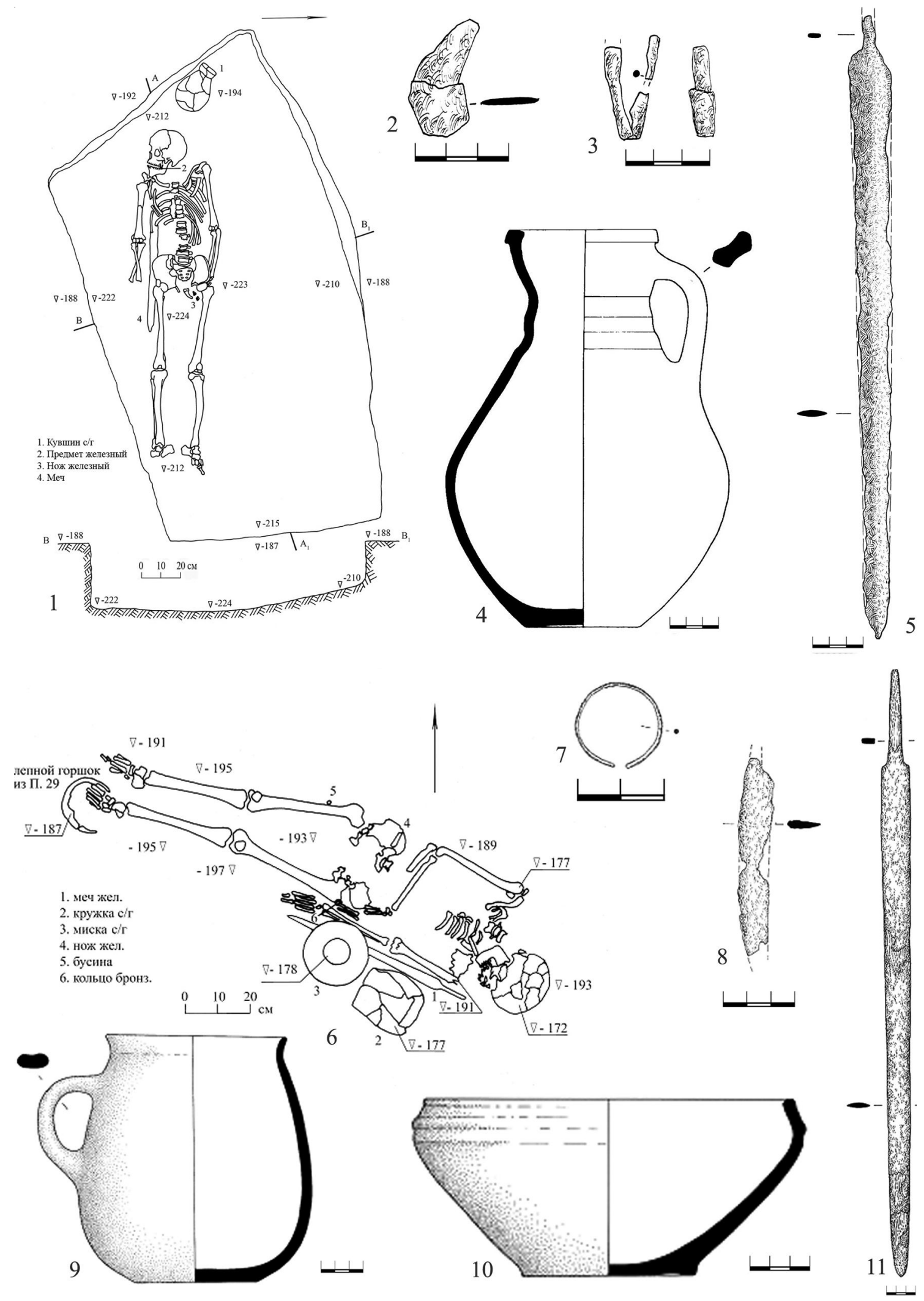

Рис. 15. Могильник Старокорсунского городища № 2:

1-5 - погребение № 3793; 6-11 - погребение № 329в

Fig. 15. Burial ground of the Starokorsunskaya settlement No. 2:

1-5 - burial No. 3793; 6-11 - burial No. 329в 

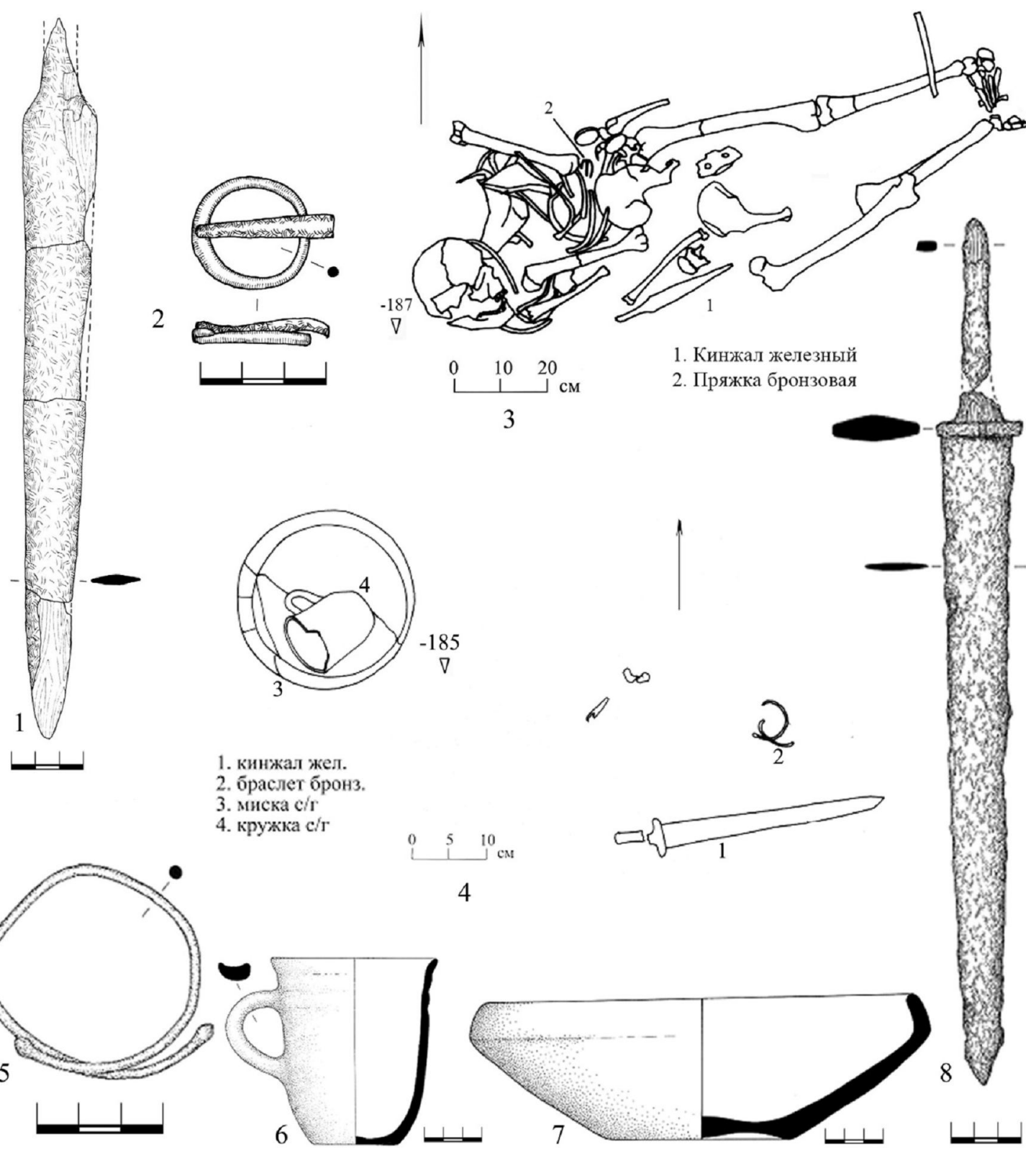

Рис. 16. Могильник Старокорсунского городища № 2:

1-3 - погребение № 5543; 4-8 - погребение № 326в

Fig. 16. Burial ground of the Starokorsunskaya settlement No. 2:

$$
\text { 1-3 - burial No. 5543; 4-8 - burial No. 326в }
$$




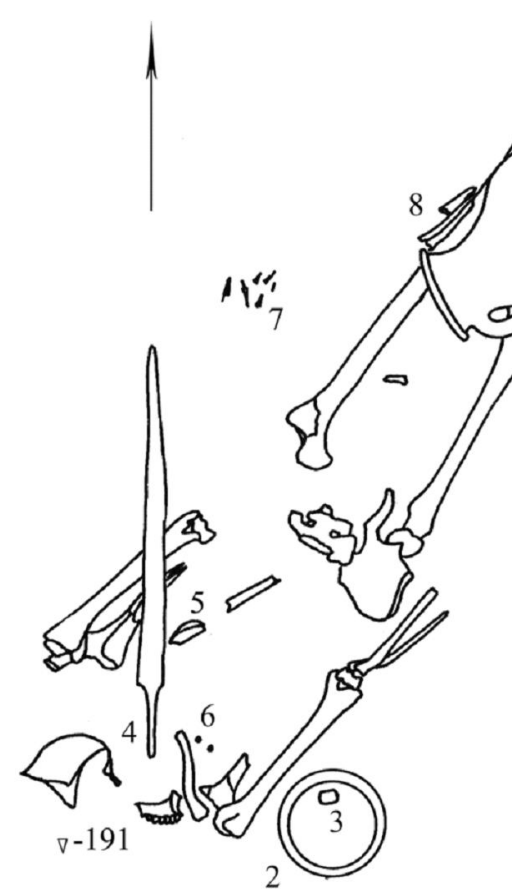

1

1. с/г кувшин

2. с/г миска

3. мел

4. меч железный

5. раковина

6. бусы

7. наконечники стрел

8. наконечник дротика железный

9. наконечник копья железный
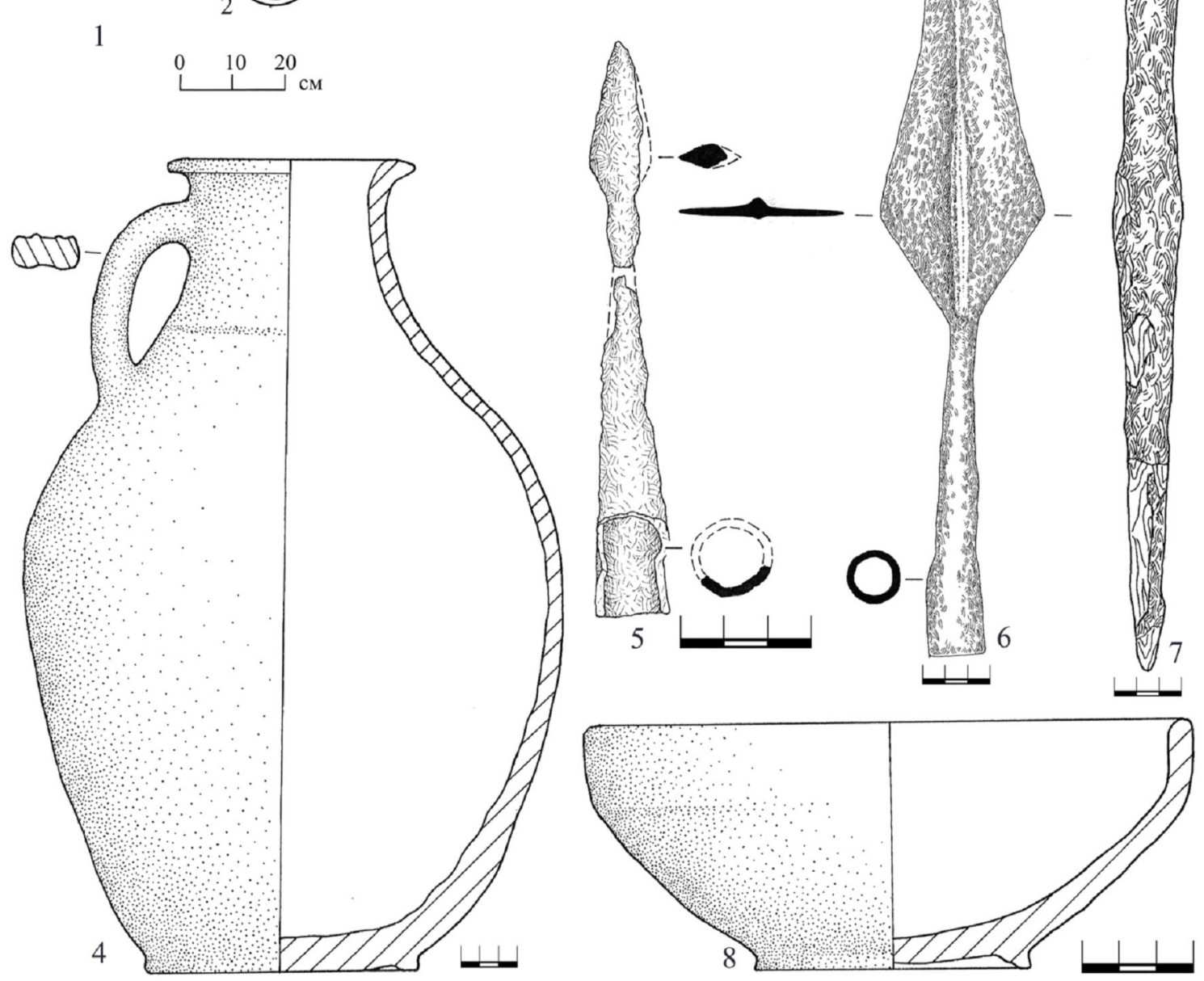

Рис. 17. Могильник Старокорсунского городища № 2, погребение № 4823

Fig. 17. Burial ground of the Starokorsunskaya settlement No. 2, burial No. 4823 


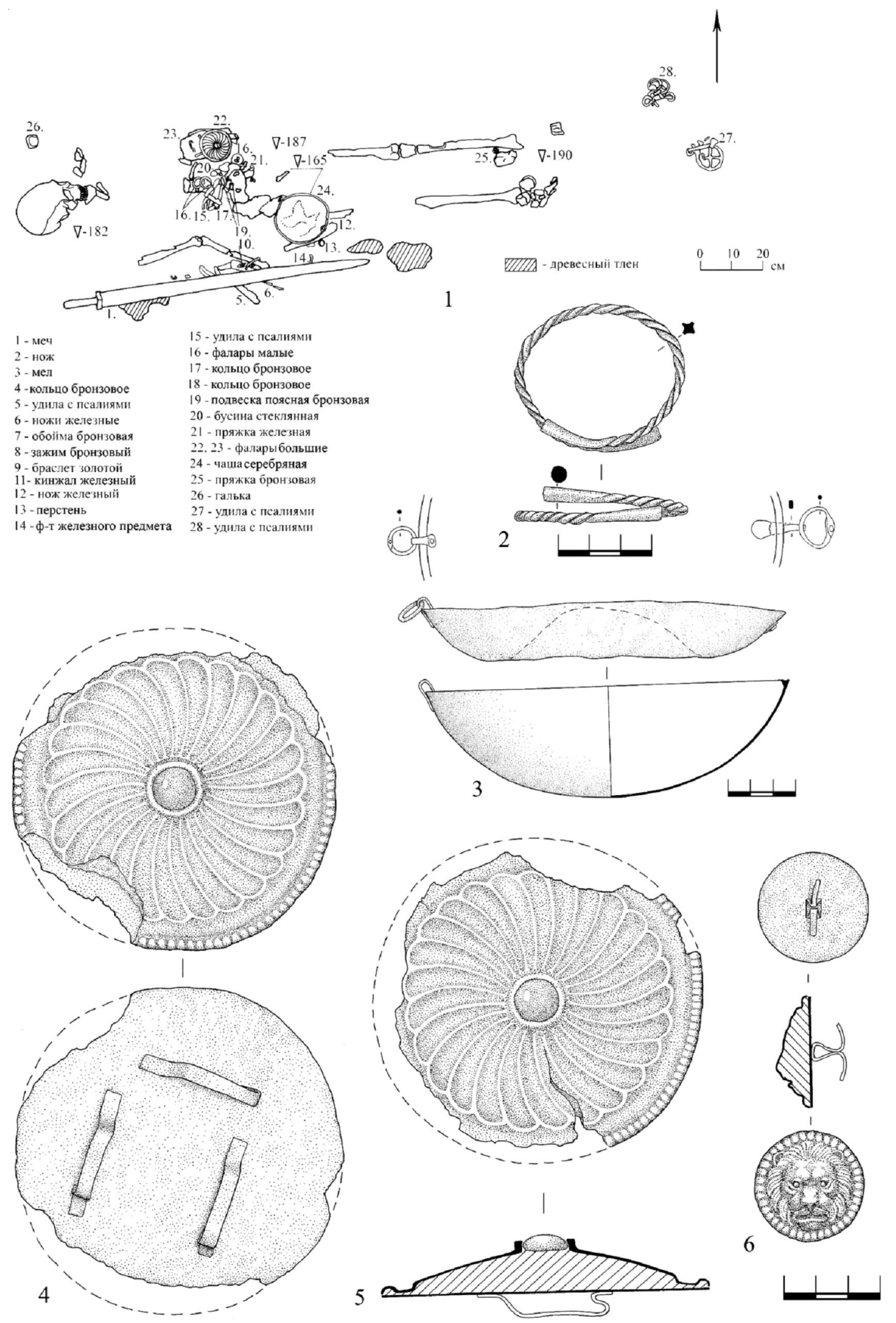

Рис. 18. Могильник Старокорсунского городища № 2, погребение № 6133

Fig. 18. Burial ground of the Starokorsunskaya settlement No. 2, burial No. 6133 


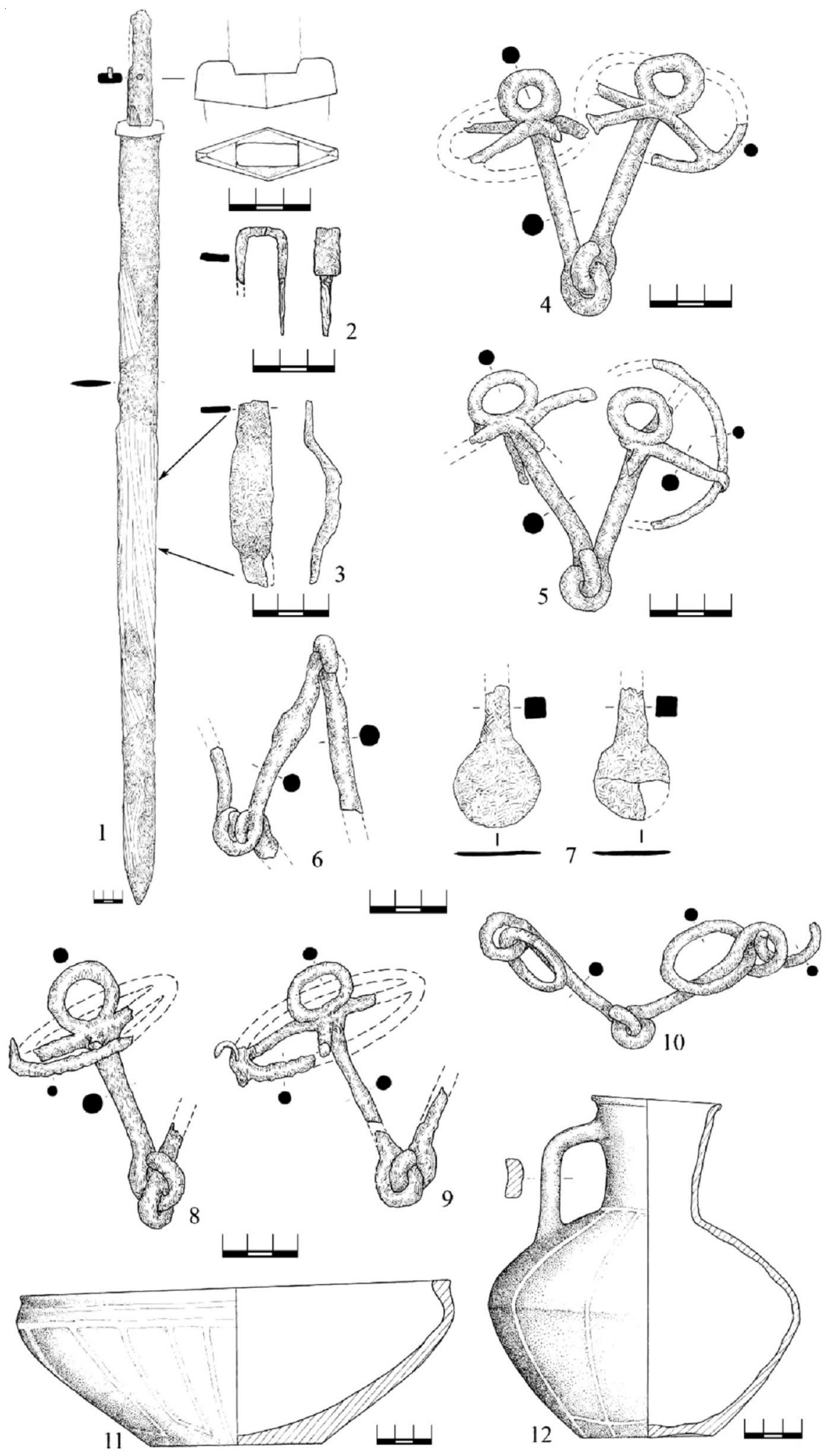

Рис. 19. Могильник Старокорсунского городища № 2, погребение № 6133

Fig. 19. Burial ground of the Starokorsunskaya settlement No. 2, burial No. 6133 


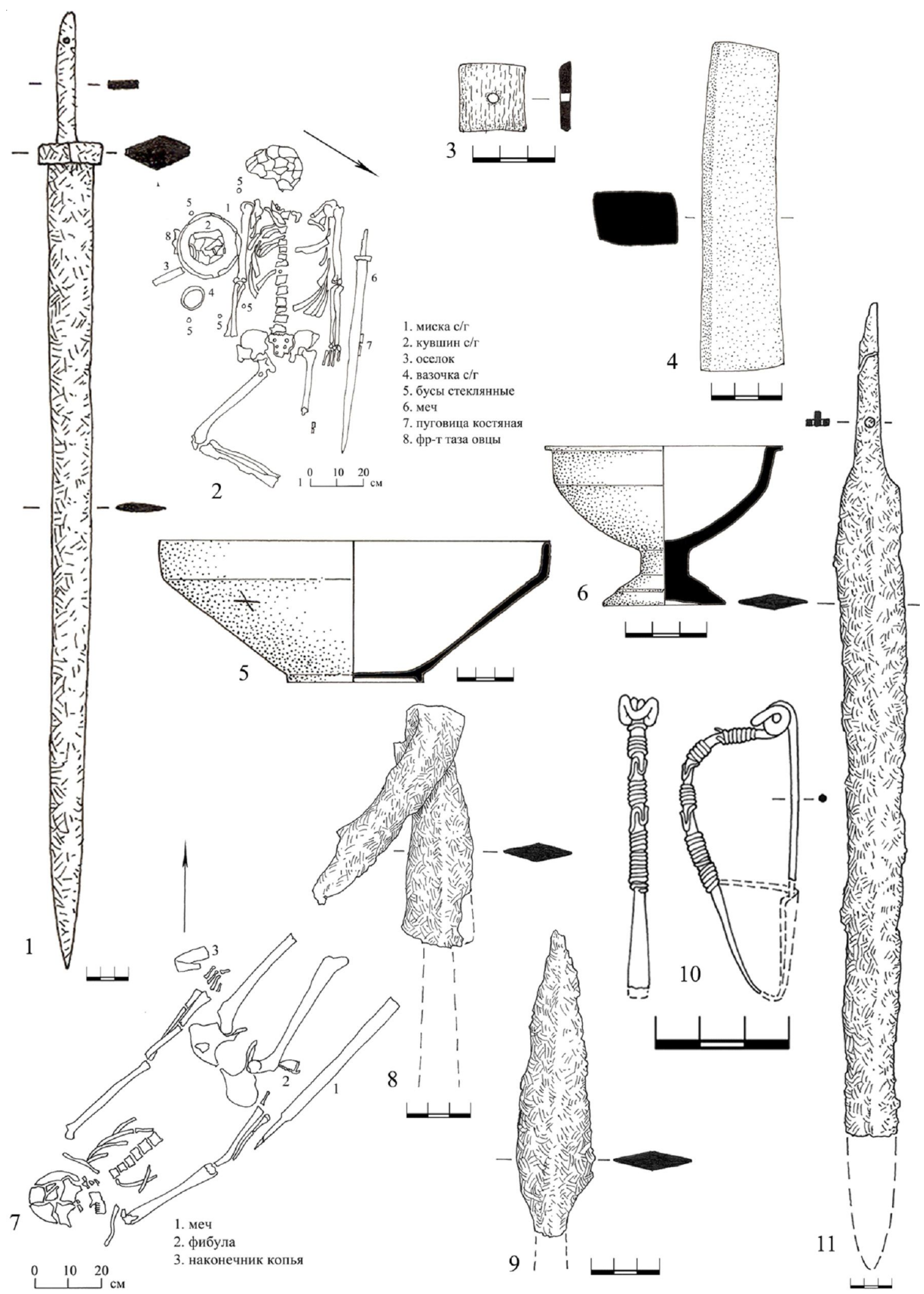

Рис. 20. Могильник городища № 1 хут. Ленина:

1-6 - погребение № 33/1980; 7-11 - погребение № 27/1983

Fig. 20. Burial ground of the Lenin No. 1 settlement:

1-6 - burial No. 33/1980; 7-11 - burial No. 27/1983 
N.Yu. Limberis, I.I. Marchenko, A.V. Kondratenko. Swords and Daggers Without a Metal Pommel

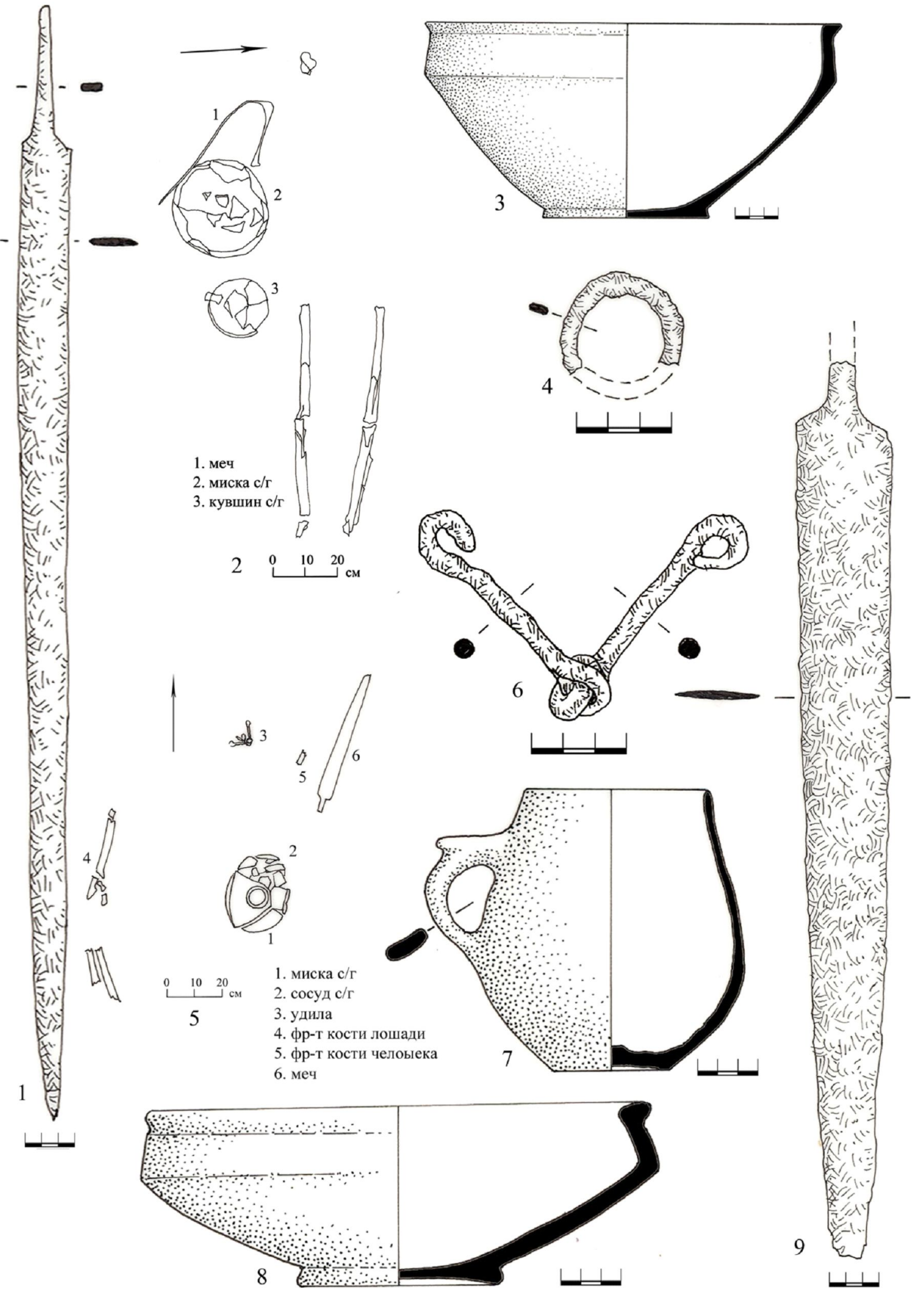

Рис. 21. Могильник городища № 1 хут. Ленина:

1-4 - погребение № 64/1980; 5-9 - погребение № 138/1981

Fig. 21. Burial ground of the Lenin No. 1 settlement:

1-4 - burial No. 64/1980; 5-9 - burial No. 138/1981 


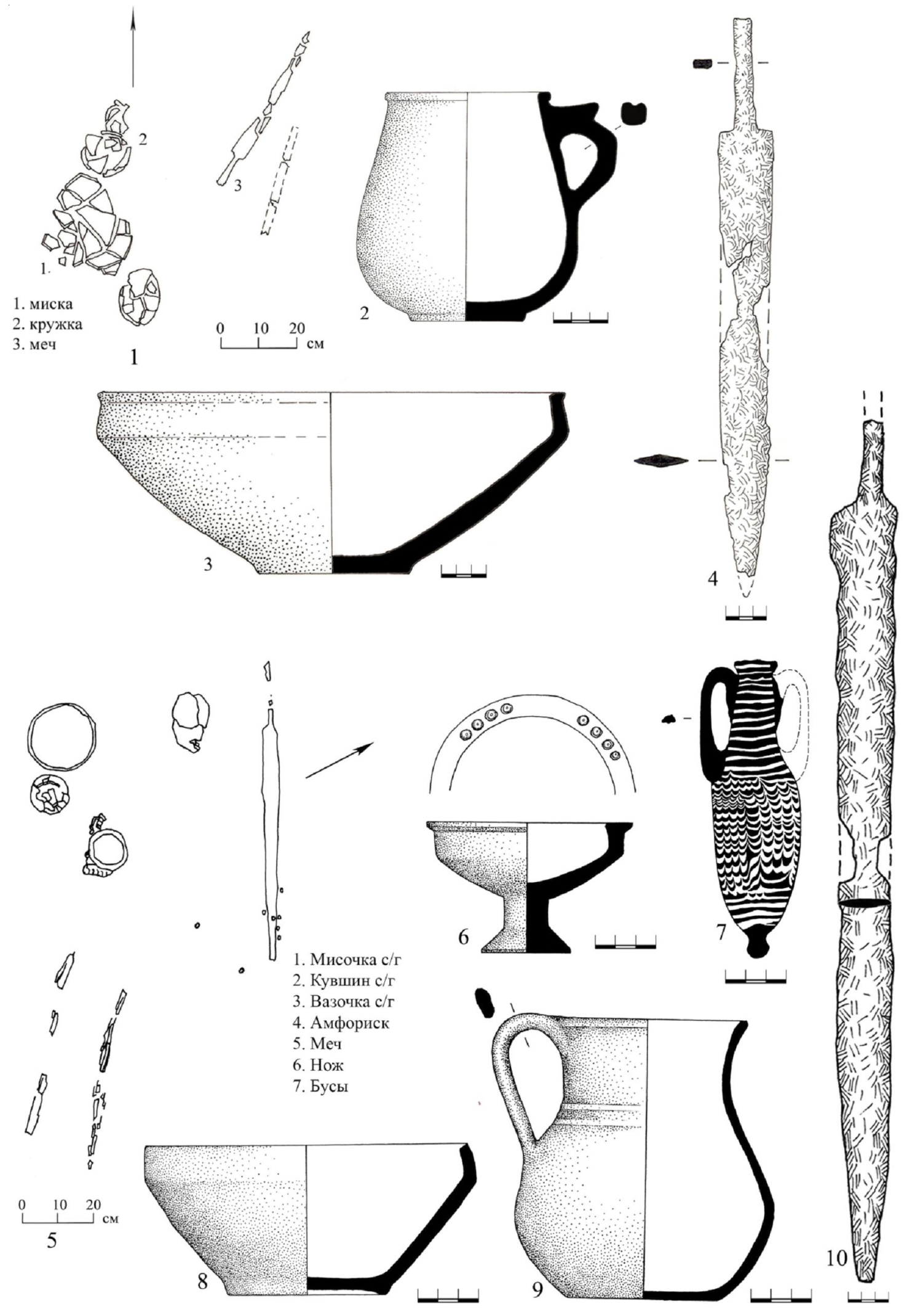

Рис. 22. Могильник городища № 1 хут. Ленина:

1-4 - погребение № 4/1983; 5-10 - погребение № 306/1981

Fig. 22. Burial ground of the Lenin No. 1 settlement:

1-4 - burial No. 4/1983; 5-10 - burial No. 306/1981 
N.Yu. Limberis, I.I. Marchenko, A.V. Kondratenko. Swords and Daggers Without a Metal Pommel

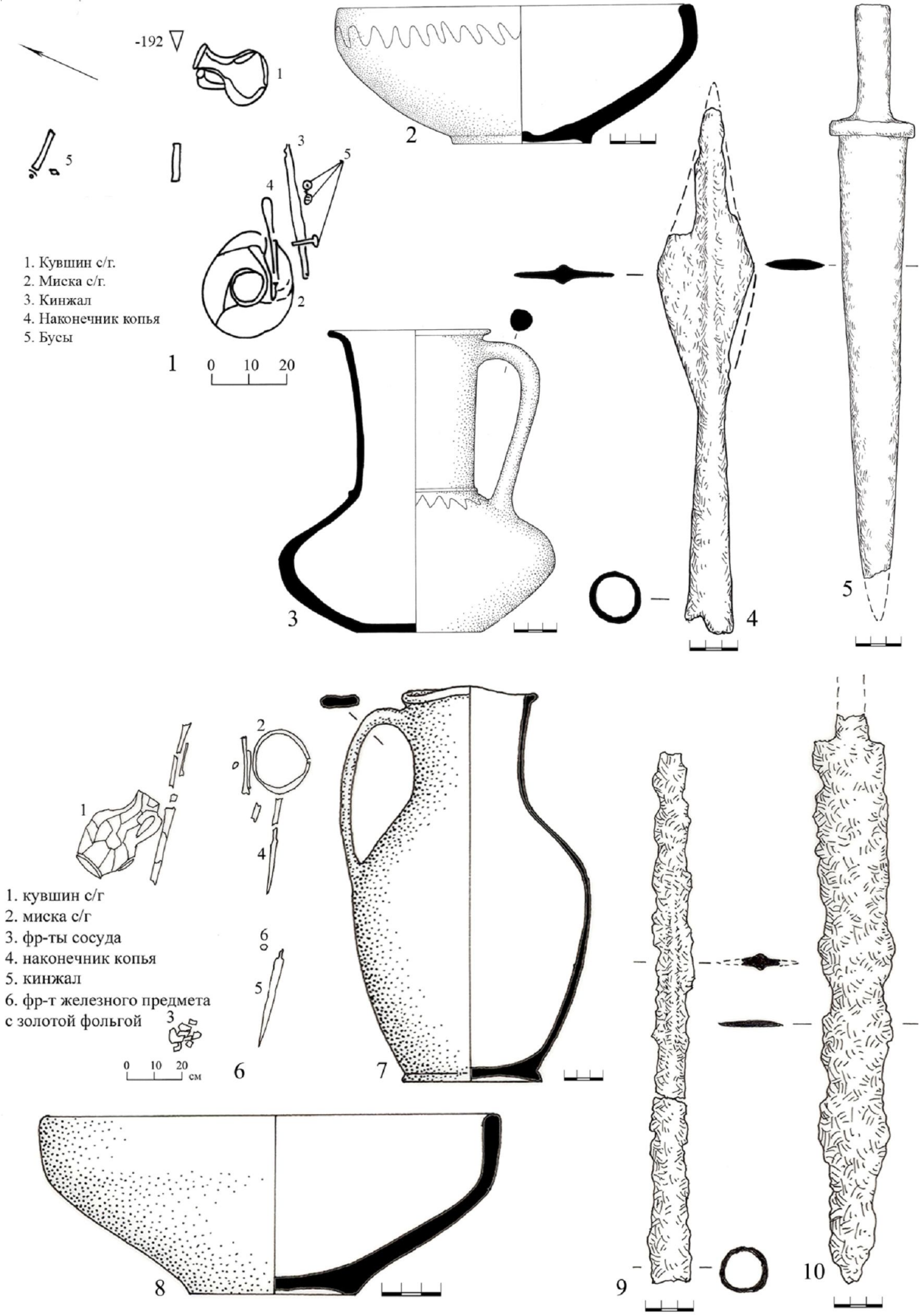

Рис. 23. Могильник городища № 1 хут. Ленина:

1-5 - погребение № 20/1981; 6-10 - погребение № 140/1981

Fig. 23. Burial ground of the Lenin No. 1 settlement:

1-5 - burial No. 20/1981; 6-10 - burial No. 140/1981 


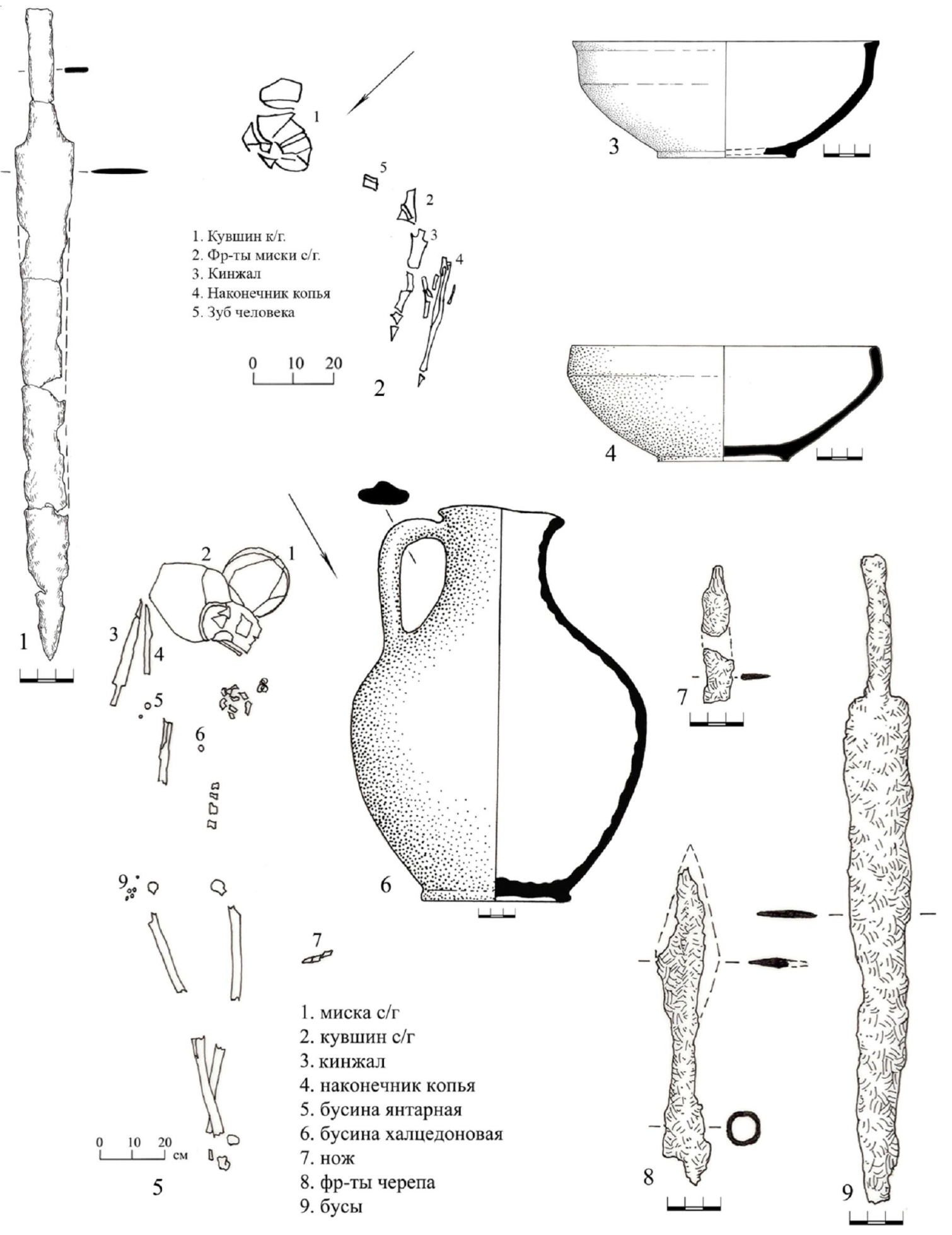

Рис. 24. Могильник городища № 1 хут. Ленина:

1-3 - погребение № 174/1981; 4-9 - погребение № 377/1981

Fig. 24. Burial ground of the Lenin No. 1 settlement:

1-3 - burial No. 174/1981; 4-9 - burial No. 377/1981 
N.Yu. Limberis, I.I. Marchenko, A.V. Kondratenko. Swords and Daggers Without a Metal Pommel

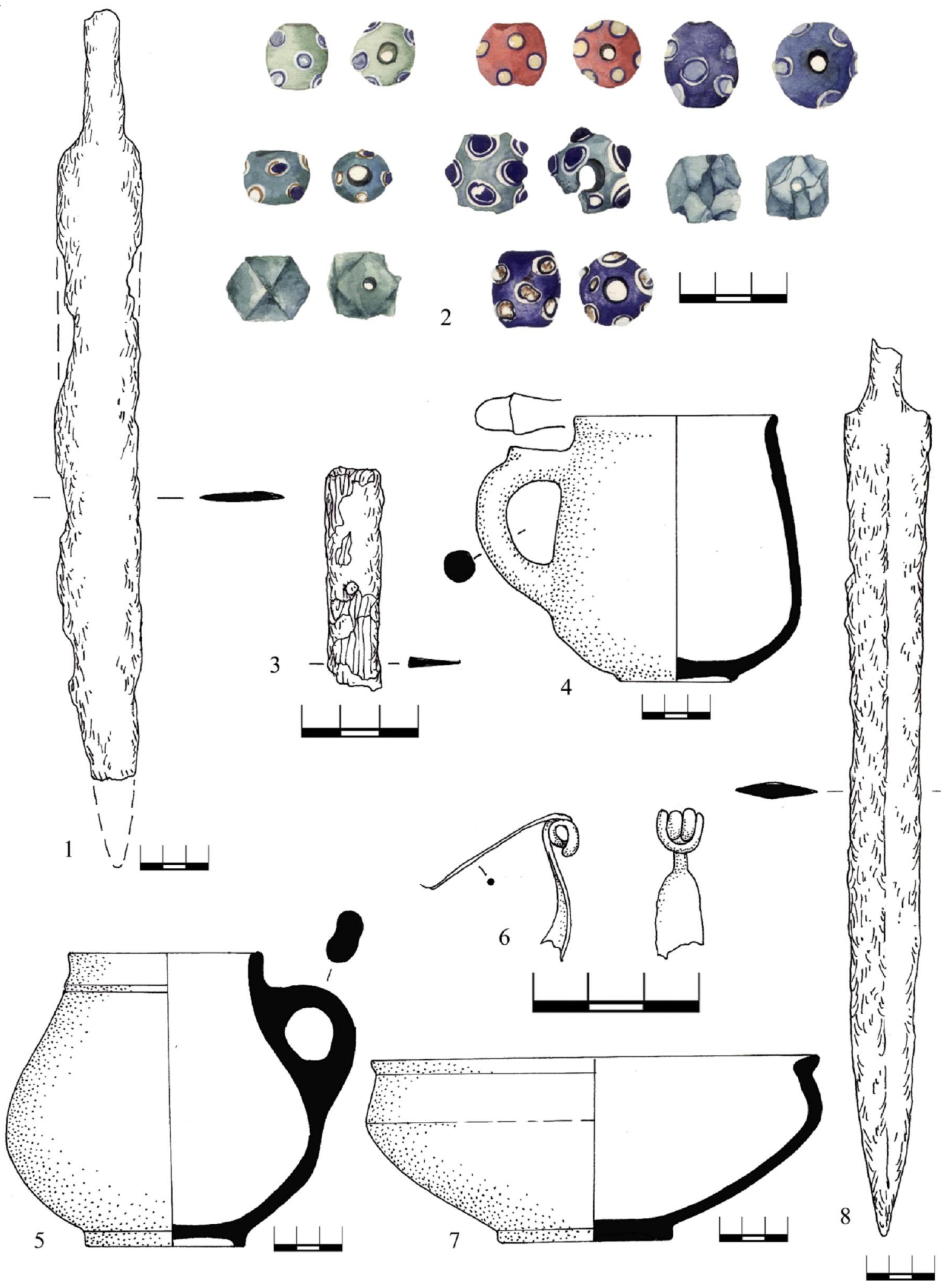

Рис. 25. Могильник городища № 1 хут. Ленина:

1-4 - погребение № 289/1981; 5-8 - погребение № 255/1981

Fig. 25. Burial ground of the Lenin No. 1 settlement:

1-4 - burial No. 289/1981; 5-8- burial No. 255/1981 

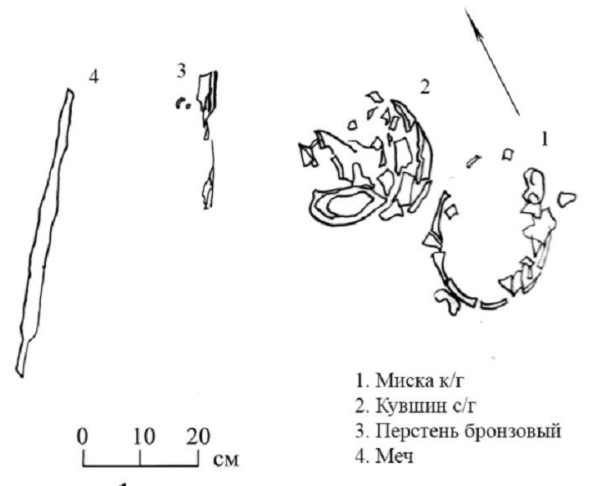

1. Миска к/

2. Кувшин $\mathrm{c} / \mathrm{r}$

3. Перстень бронзовый

4. Мeч
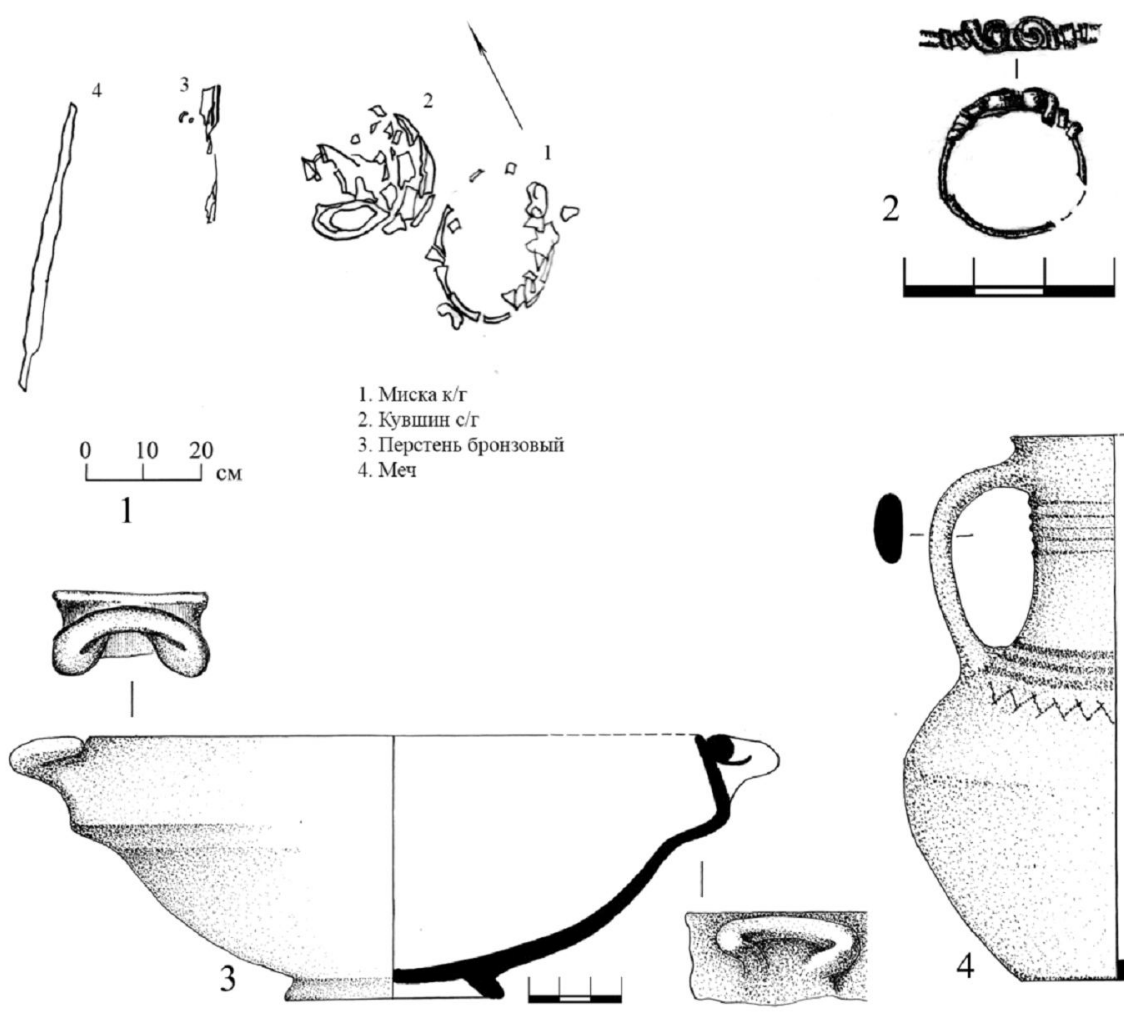

1
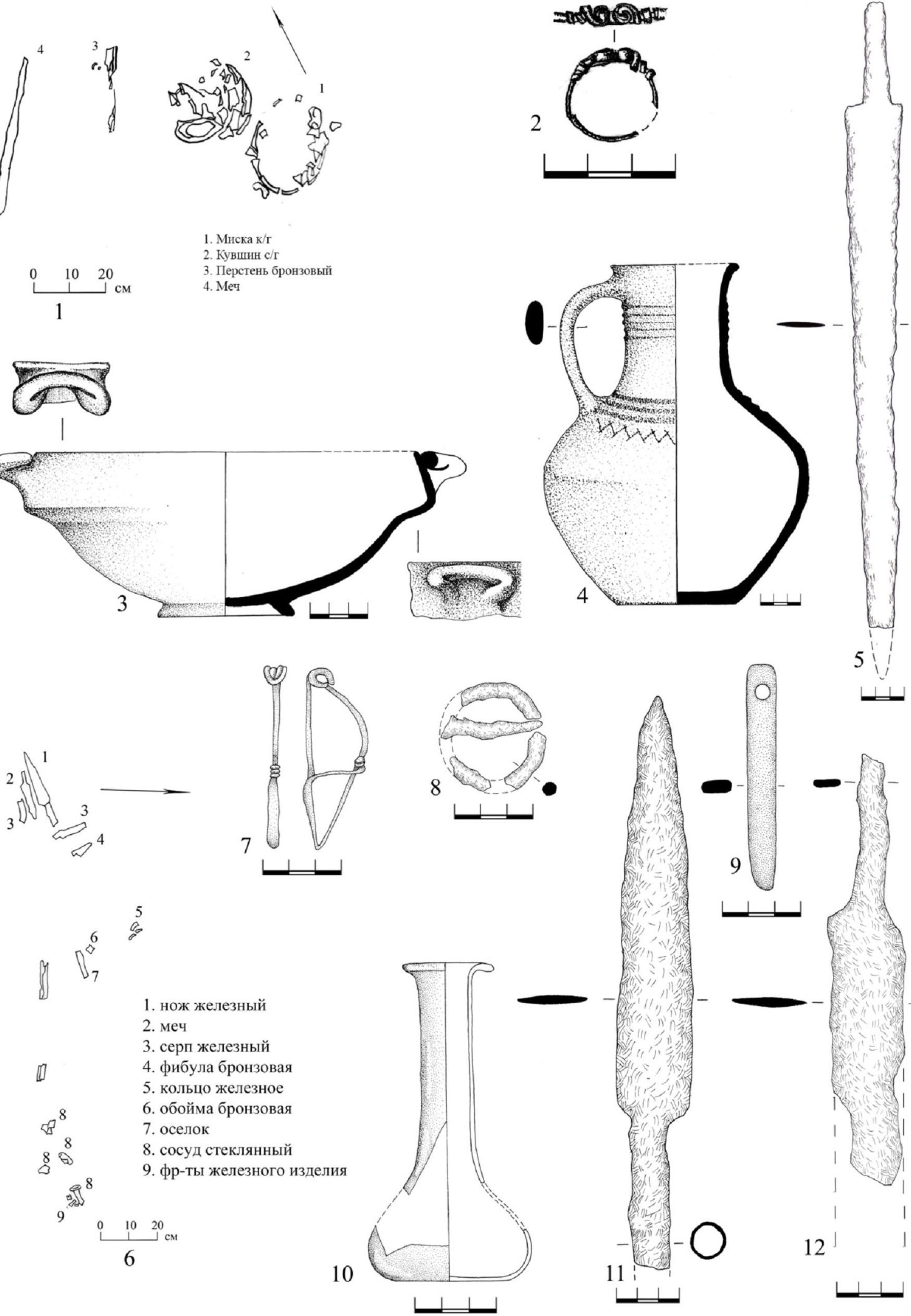

Рис. 26. Могильник городища № 1 хут. Ленина:

1-5 - погребение № 359/1981; 6-12 - погребение № 364/1981

Fig. 26. Burial ground of the Lenin No. 1 settlement:

1-5 - burial No. 359/1981; 6-12 - burial No. 364/1981 

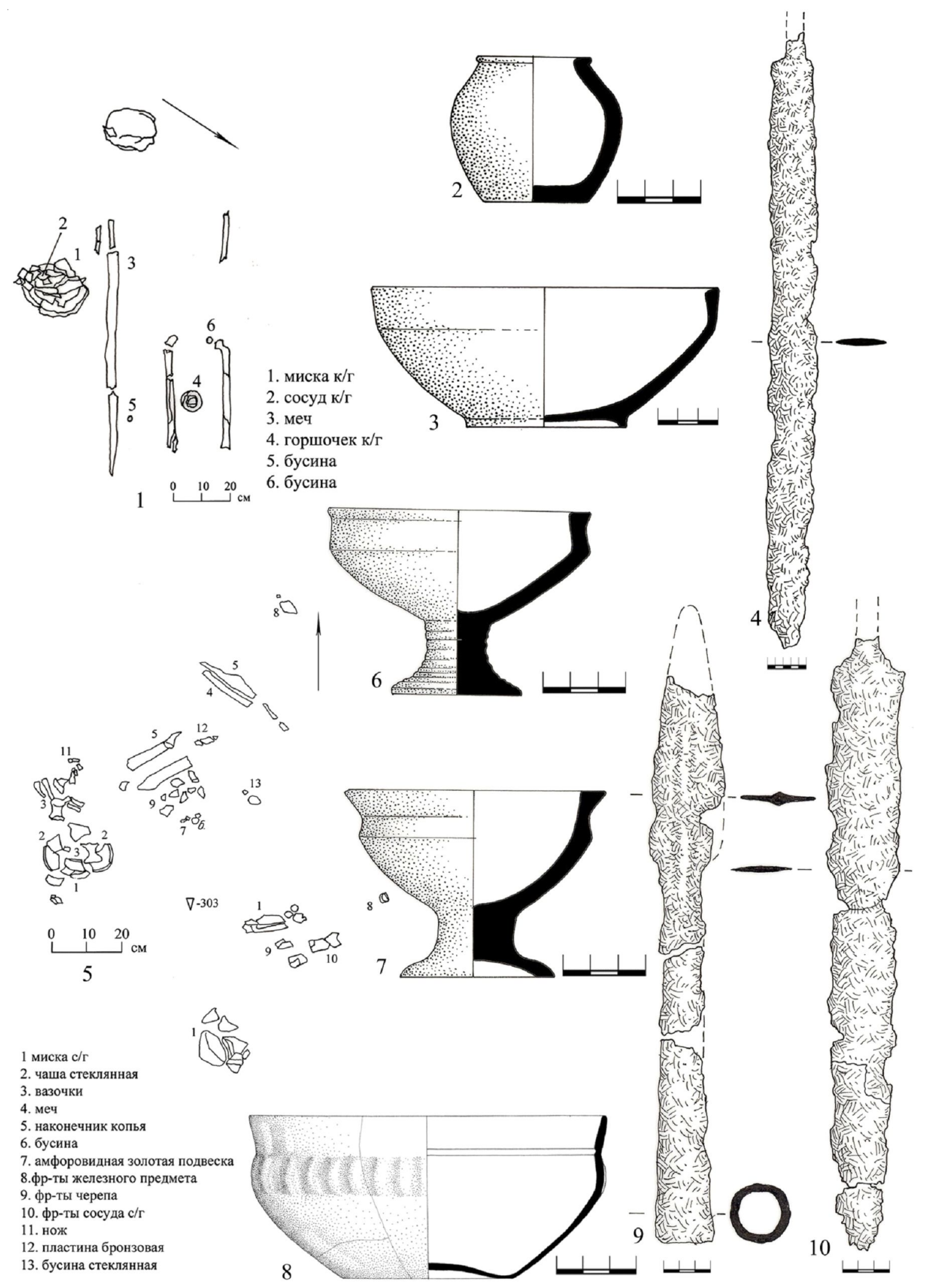

Рис. 27. Могильник городища № 1 хут. Ленина:

1-4 - погребение № 392/1981; 5-10 - погребение № 419/1981

Fig. 27. Burial ground of the Lenin No. 1 settlement:

1-4 - burial No. 392/1981; 5-10 - burial No. 419/1981 
Н.Ю. Лимберис, И.И. Марченко, А.В. Кондратенко. Мечи и кинжалы без металлического навершия

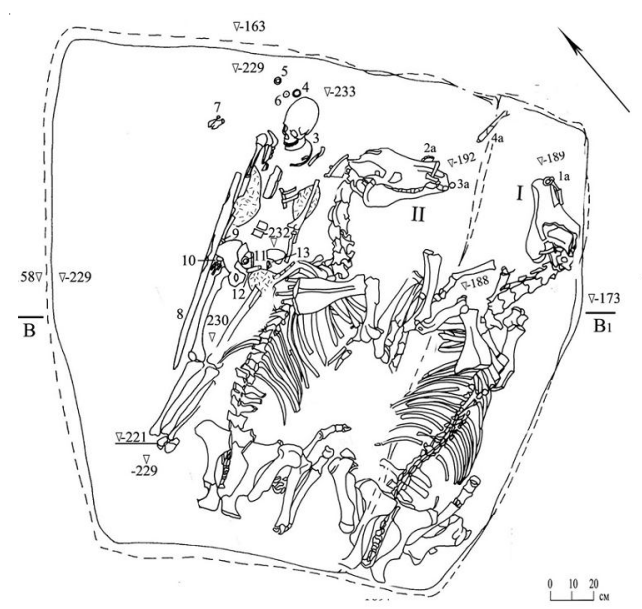

1а, 2а. Удила железные

3а. Бусина золотая

运- органический тлен

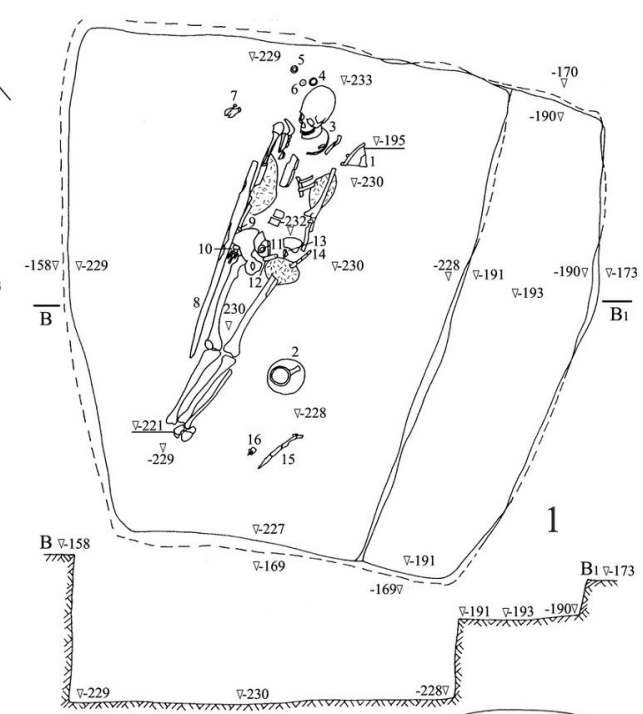

1. Умбон железный

2. Кувшин $\mathrm{c} / \mathrm{r}$

3. Гривна серебряная

4, 5. Кольца бронзовы

6. Бляшка бронзовая

7. Фрагменты гривны

8. Меч железный

9. Браслет серебряный

1.. Пряма серебрян

12. Оселок

14. Нож железный

15. Серп железный

15. Серп железный
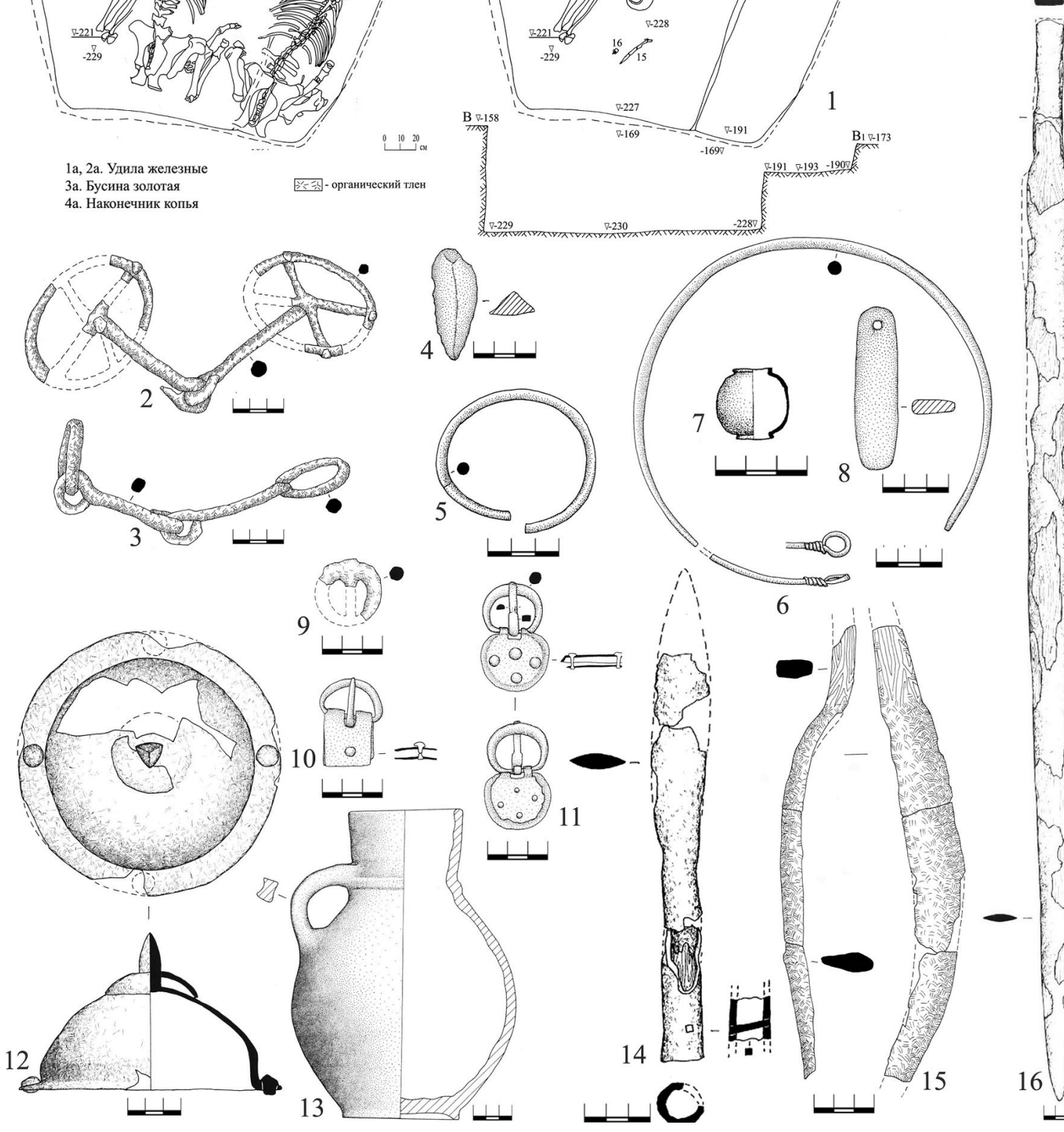

8
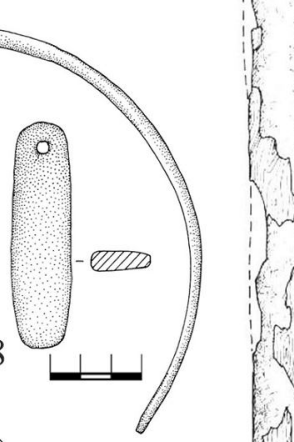

Рис. 28. Могильник городища Спорное, погребение № 161

Fig. 28. Burial ground of the Spornoye settlement, burial No. 161 
N.Yu. Limberis, I.I. Marchenko, A.V. Kondratenko. Swords and Daggers Without a Metal Pommel

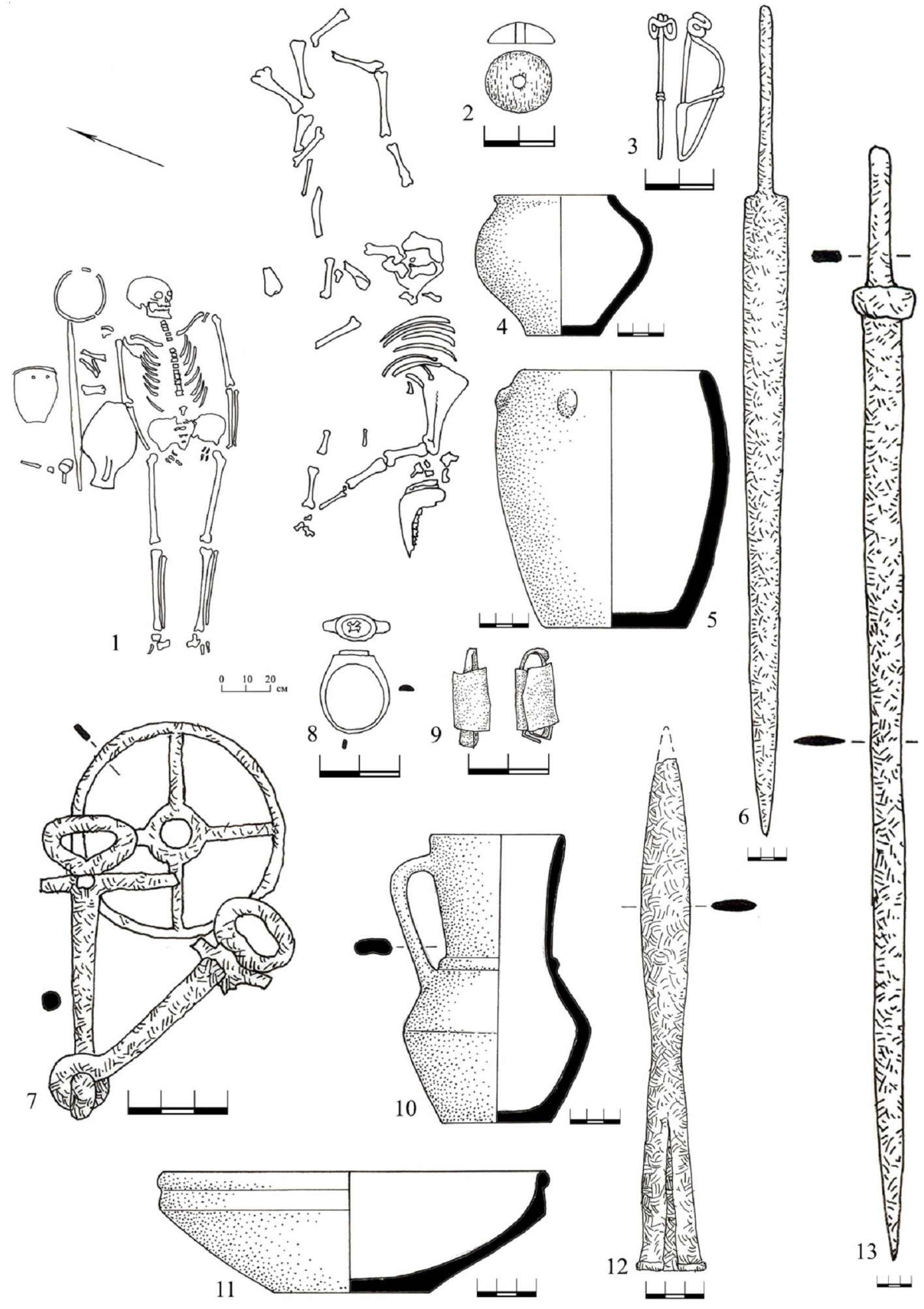

Рис. 29:

1-6 - Могильник Усть-Лабинского городища № 2, погребение № 81/1938;

7-13 - Могильник Елизаветинского городища № 2, погребение № 93/1978

Fig. 29:

1-6 - Burial ground of the Us't-Labinsk settlement No. 2, burial No. 81/1938;

7-13 - Burial ground of the Elisavetinskaya settlement No. 2, burial No. 93/1978 


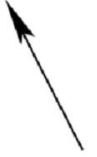
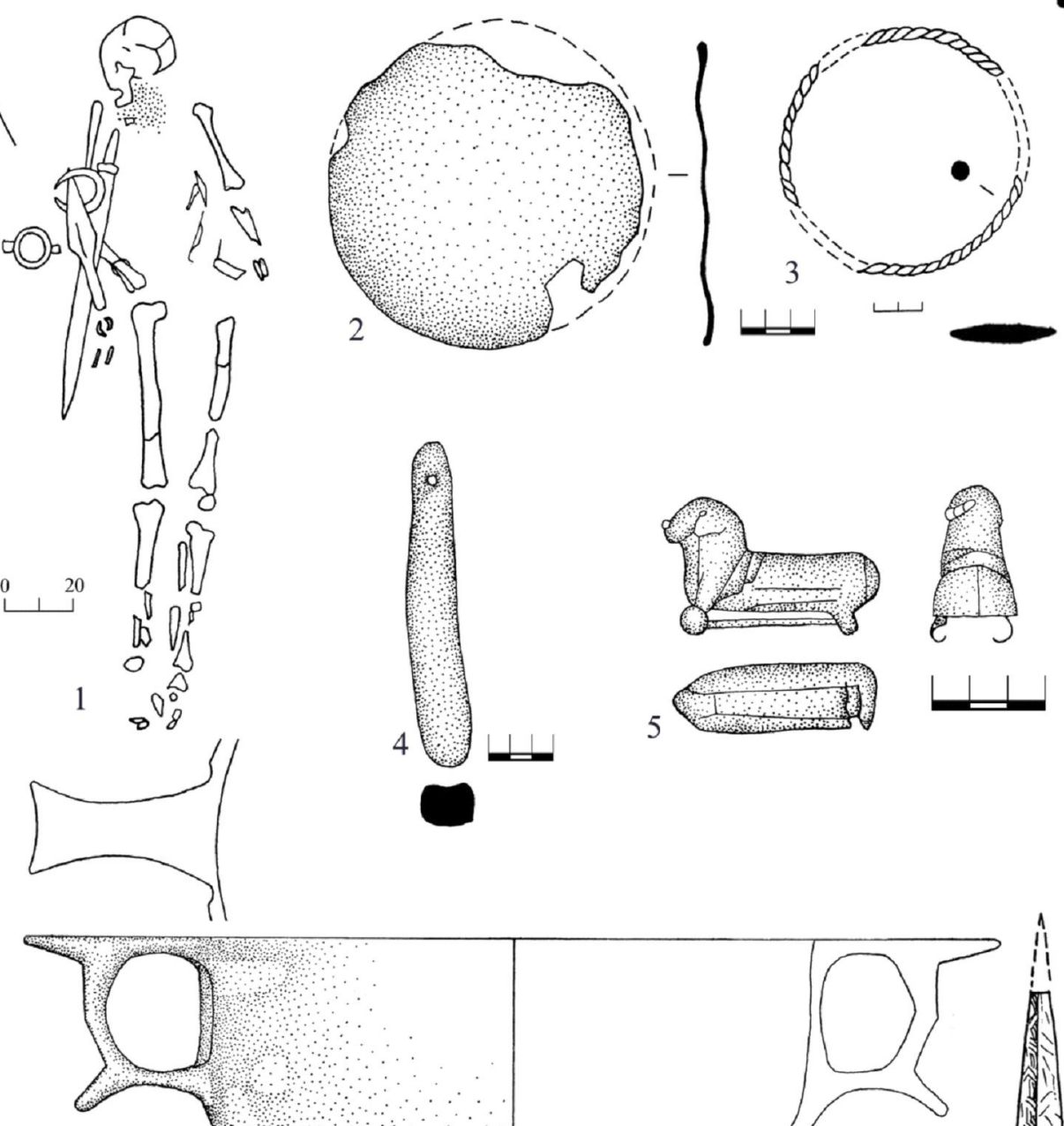

$\rightarrow-$

.<smiles>C1=CCCCC1</smiles>
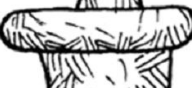

Not

-
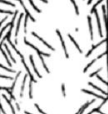

i倡
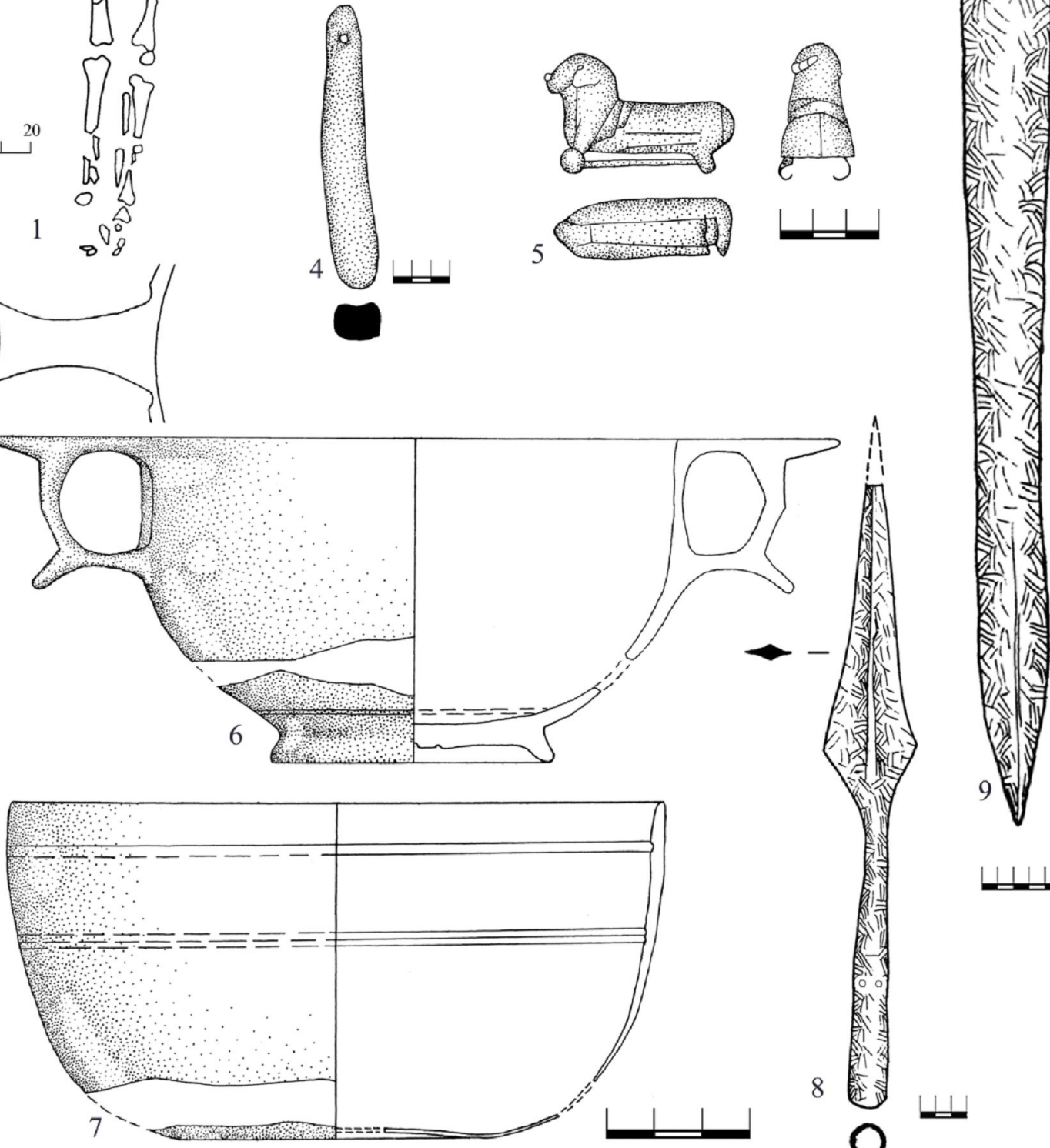

Рис. 30. Могильник Елизаветинского городища № 2, погребение № 31/1978

Fig. 30. Burial ground of the Elisavetinskaya settlement No. 2, burial No. 31/1978 


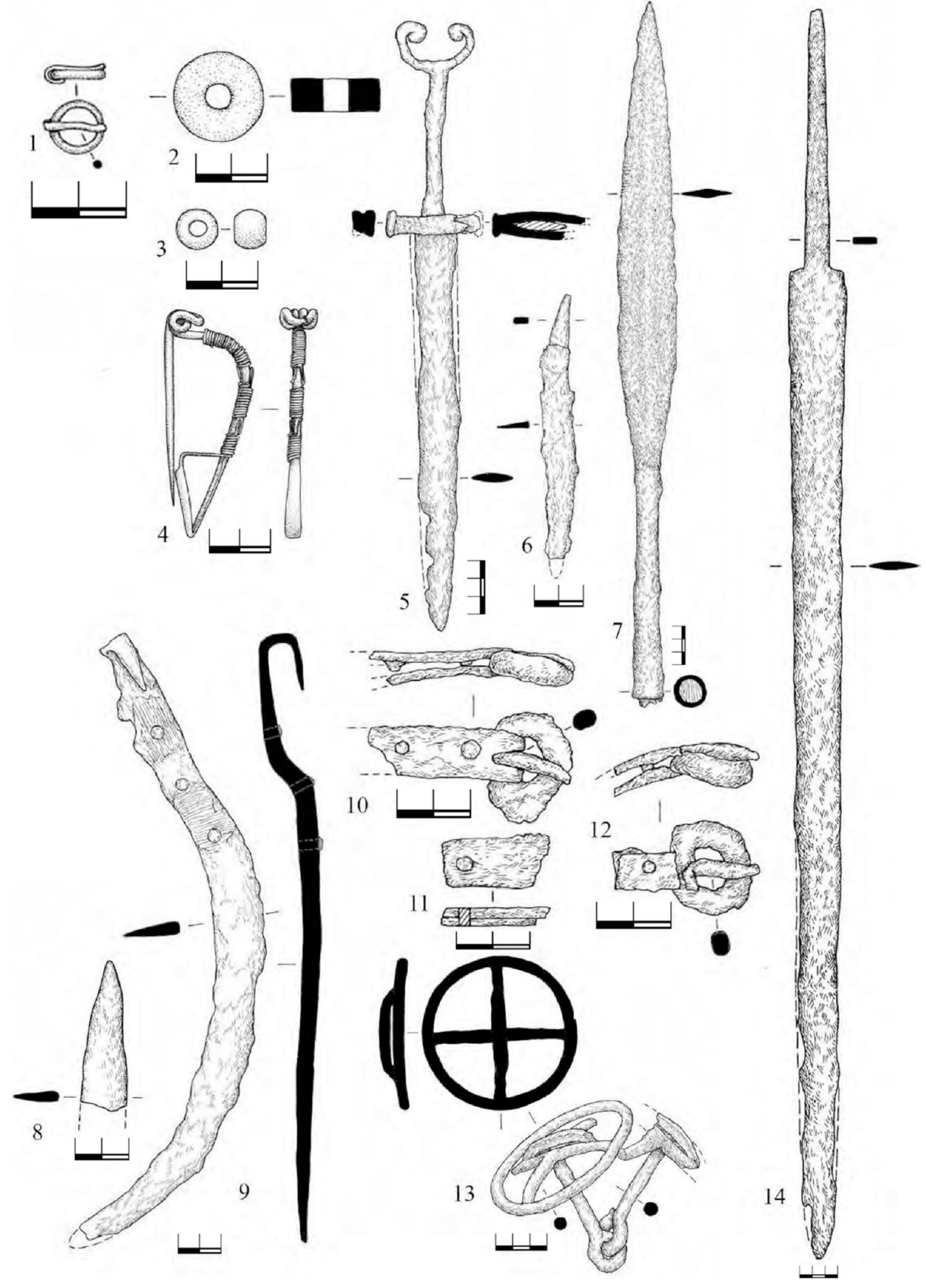

Рис. 31. Могильник № 2 Пашковского городища № 1, погребение № 1

Fig. 31. Burial ground No. 2 of the Pashkovskaya settlement No. 1, burial No. 1 


\section{СПИСОК ЛИТЕРАТУРЫ}

Абрамова М. П., 1993. Центральное Предкавказье в сарматское время (III в. до Н.э. - IV в. н.э.). М. : ИА РАН. 240 с. Алексеева Е. М., 1978. Античные бусы Северного Причерноморья. САИ. Вып. ГІ-12. М. : Наука. 97 с., 34 табл.

Амброз А. К., 1966. Фибулы юга европейской части СССР ІІ в. до н. э. - IV в. н. э. САИ. Д1-30. М. : Наука. 111 с., 28 табл.

Анфимов И. Н., 1984. Меотский могильник I-II вв. н.э. близ станицы Елизаветинской // Вопросы археологии Адыгеи. Майкоп : Адыгейский НИИЭЯЛИ. С. 83-114.

Анфимов Н. В., 1951. Меото-сарматский могильник у станицы Усть-Лабинской // Материалы и исследования по археологии. Вып. 23. М. : Изд-во АН СССР. С. 155-207.

Анфимов Н. В., 1967. Отчет об археологических исследованиях, проводившихся в Краснодарском крае в 1966 г. // Архив ИА РАН. Р-1, № 3806.

Анфимов Н. В., 1968. Отчет об археологических работах, связанных с охранными мероприятиями, проведенных в 1967 году // Архив ИА РАН. Р-1, № 3807.

Анфимов Н. В., 1973. Отчет о раскопках Пашковского 5-го могильника в 1972 г. // Архив ИА РАН. Р-1, № 6505.

Безуглов С. И., 2000. Позднесарматские мечи (по материалам Подонья) // Сарматы и их соседи на Дону. Материалы и исследования по археологии Дона. Вып. 1. Ростов н/Д : Терра. С.169-193.

Волошинов А. А., Масякин В. В., Неневоля И. И., 2007. Два комплекса с римскими импортами из Краснозоринского некрополя // Древняя Таврика. Симферополь : Универсум. С. 303-318.

Иванов А. В., 2008. О длинных мечах без металлического перекрестия и навершия (по материалам меотских памятников Кубани) // Материалы и исследования по археологии Кубани. Вып. 9. Армавир : Армавирский государственный педагогический университет. С. 75-84.

Косяненко В. М., 1989. Новые материалы позднеантичного времени с территории г. Ростов-на-Дону // Историко-археологические исследования в Азове и на Нижнем Дону. Вып. 8. Азов : Азовский краеведческий музей. С. 58-62.

Косяненко В. М. 2008. Некрополь Кобякова городища (по материалам раскопок 1956-1962 гг.) // Донские древности. Вып. 9. Азов : Азовский музей-заповедник. 554 с.

Кривошеев М. В., 2007. Вооружение позднесарматского времени Нижнего Поволжья // Вооружение сарматов : региональная типология и хронология : докл. к VI Междунар. конф. «Проблемы сарматской археологии и истории». Челябинск : Южно-Уральский ГУ. С. 65-70.

Кропотов В. В., 2010. Фибулы сарматской эпохи. Киев : ИА НАНУ ; АДЕФ-Украина. 384 с.

Кропотов В. В., Скворцов Н. В., 2020. Сарматские погребения из курганного могильника «Попов І» на Дону // Археологическое наследие. Античность. Скифы. Сарматы. № 1 (3). Воронеж : Научная книга. С. 351-359.

Кунина Н. 3., 1997. Античное стекло в собрании Эрмитажа. СПб. : Государственный Эрмитаж, АРС. 359 с.

Кунина Н. 3., Сорокина Н. П., 1972. Стеклянные бальзамарии Боспора // Труды государственного Эрмитажа. T. XIII. C. 146-177.

Лимберис Н. Ю., Марченко И. И., 2003. Стеклянные сосуды позднеэллинистического и римского времени из Прикубанья // Материалы и исследования по археологии Кубани. № 3. Краснодар : КубГУ. С. 106-183.

Лимберис Н. Ю., Марченко И. И., 2006. Типология и хронология меотских железных наконечников копий из памятников правобережья Кубани // Материалы и исследования по археологии Кубани. № 6. Краснодар : КубГУ. С. 152-181.

Лимберис Н. Ю., Марченко И. И., 2012. Погребение сарматского всадника на некрополе меотского городища // Евразия в скифо-сарматское время. Памяти Ирины Ивановны Гущиной. Труды ГИМ. Вып. 191. С. $141-154$.

Лимберис Н. Ю., Марченко И. И., 2013. Всадническое погребение с умбоном из Среднего Прикубанья // Stratum plus. № 4. С. 105-115.

Лимберис Н. Ю., Марченко И. И., 2015. Две катакомбы позднесарматского времени из Пашковского могильника № 1 // Вестник Волгоградского государственного университета. Серия 4, История. Регионоведение. Международные отношения. № 5 (35). С. 126-138. DOI: http://dx.doi.org/10.15688/jvolsu4.2015.5.12.

Лимберис Н. Ю., Марченко И. И., 2018. Хронология орнаментированных зеркал-подвесок с боковой ручкой из меотских могильников правобережья Кубани // Stratum plus. № 4. C. 201-218. 
Лимберис Н. Ю., Марченко И. И., 2019а. Погребения с мечами с кольцевым навершием из могильника меотского городища Спорное // Stratum plus. № 4. С. 189-209.

Лимберис Н. Ю., Марченко И. И., 2019б. Меотские погребения со стеклянными скифосами зубовского типа // Нижневолжский археологический вестник. Т. 18, № 2. С. 235-244. DOI: https://doi.org/10.15688/ nav.jvolsu.2019.2.15.

Лимберис Н. Ю., Марченко И. И., 2020. Хронология браслетов с коническими шишечками на концах из меотских памятников Прикубанья // Археологія і давня історія України. Вип. 3 (36). С. 423-430.

Малышев А. А., 2008. Погребальный инвентарь Цемдолинского некрополя // Аспургиане на юго-востоке азиатского Боспора. По материалам Цемдолинского могильника. М. : ИА РАН. С. 136-180.

Маслов В. Е., 1999. О датировке изображений на поясных пластинах из Орлатского могильника // Евразийские древности. 100 лет Б. Н. Гракову : архив. материалы, публ., ст. М. : ИА РАН. С. 219-236.

Марченко И. И., 1996. Сираки Кубани (По материалам курганных погребений Нижней Кубани). Краснодар : КубГУ. 336 с.

Симоненко А. В., 2010. Сарматские всадники Северного Причерноморья. СПб. : Нестор-История. 328 с.

Скрипкин А. С., 2000. Новые аспекты в изучении истории материальной культуры сарматов // Нижневолжский археологический вестник. Вып. 3. С. 17-40.

Скрипкин А. С., Клепиков В. М., 2020. Археологические памятники II-I вв. до н.э. Нижнего Поволжья и некоторые этнические проблемы сарматов // Археологія і давня історія України. Вип. 3 (36). С. 214-222.

Сымонович Э. А., 1983. Население столицы позднескифского царства (по материалам Восточного могильника Неаполя скифского). Киев : Наукова думка. 175 с.

Труфанов А. А., 2009. Хронология могильников Предгорного Крыма І в. до н.э. - III в. н. э. // Stratum plus. № 4. C. $117-329$.

Хазанов А. И., 1971. Очерки военного дела сарматов. М. : Наука. 169 с.

Almgren O., 1923. Studien über nordeuropäische Fibelformen der ersten nachchrislichen Jahrhunderte mit Berücksicktigung der provinzialrömischen und südrussischen Formen. Mannus-Bibliothek. Bd. 32. Leihzig : Curt Kabitzsch. 254 s.

Dusenbery E. B., 1967. Ancient Glass from Cemeteries of Samophfrace // Journal of Glass Studies. Vol. 9. P. 34-49.

Dusenbery E. B., 1998. Samophrace. II. The necropoleis. The necropoleis and catalogues of burials. Catalogues of Objects by categories. Princeton : Princeton University Press. 1252 p.

Grose D. F., 1989. Early Ancient Glass : Core-formed, Rod-formed, and Cast Vessels and Objects from Late Bronze Age to the Early Roman Empire, 1600 B.C. to A.D. 50. N. Y. : Hudson Hill Press. 453 p.

Hayes J. W., 1975. Roman and Pre-Roman Glass in the Royal Ontario Museum. Toronto : Royal Ontario Museum. $229 \mathrm{p}$.

Fünfschilling S., 2015. Die römischen Gläser aus Augst und Kaiseraugst. Forschungen in Augst. Bd. 51. August : Museum Augusta Raurica. $711 \mathrm{~s}$.

Ettlinger E., 1973. Die römischen Fibeln in der Schweiz. Bern : Francke. 198 s.

Isings C., 1957. Roman Glass from Dated Finds. Djakarta, Groningen : J.B. Wolters Publ. 183 p.

Marčenko I. I., Limberis N. Ju., 2008. Römische importe in sarmatischen und maiotischen Denkmälern des Kubangebietes // Simonenko A., Marčenko I. I., Limberis N. Ju. Römische Importe in sarmatischen und maiotischen Gräbern. Archäologie in Eurasien. Bd. 25. Mainz : Philipp von Zabern. S. 265-400, 222 taf.

Riha E., 1994. Die römischen Fibeln aus Augst und Kaiseraugst. Die Neufunde seit 1975. Forschungen in Augst. Bd. 18. August : Museum Augusta Raurica. $206 \mathrm{~s}$.

Rotroff S. I., 1997. Hellenistic Pottery. Athenian and Imported Wheelmade Table Ware and Related Material. The Athenian Agora. Vol. XXIX. Princeton, New Jersey: The American school of classic studies in Athens. 979 p.

Robinson H. S., 1959. Pottery of the Roman Period chronology. The Athenian Agora. Vol. V. Princeton, New Jersey : The American school of classic studies in Athens. 149 p.

Rütti B., 1991. Die römischen Gläser aus Augst und Kaiseraugust. Forschungen in Augst. Bd. 13. Nr. 1. August : Museum Augusta Raurica. 370 p.

Thompson H. A., 1934. Two Centuries of Hellenistic Pottery. The American Excavation in the Athenian Agora. Fifth Report // Hesperia. Vol. III. No. 4. Athens, The American school of classic studies in Athens. P. 311-480. 


\section{REFERENCES}

Abramova M.P., 1993. Central'noe Predkavkaz'e v sarmatskoe vremya (III v. do n.e. - IV v. n.e.) [Cenral Ciscaucasia in the Samatian Period ( $3^{\text {nd }}$ Century BC $-4^{\text {th }}$ CenturyAD) $]$. Moscow, IA RAS. 240 p.

Alekseeva E.M., 1978. Antichnye busy Severnogo Prichernomor'ya [Antique Beads of the Northern Pontic Region]. Svod arkheologicheskih istochnikov. ГI-12. Moscow, Nauka Publ. 97 p., 34 tabl.

Ambroz A.K., 1966. Fibuly yuga Evropejskoj chasti SSSR II v. do n. e. - IV v. n. e. [Fibulae of the South European Part of USSR $2^{\text {nd }}$ Century BC $-4^{\text {th }}$ Century AD)] Svod arkheologicheskih istochnikov. Д1-30. Moscow, Nauka Publ. 111 p., 28 tabl.

Anfimov I.N., 1984. Meotskiy mogil'nik I-II vv. n. e. bliz stanitsy Elizavetinskoy [Maeotian Cemetery of the First Centuries AD Near the Village of Elizavetinskaya]. Voprosy arkheologii Adygei [Issues of Archaeology of Adygea]. Maykop, ARIELH, pp. 83-114.

Anfimov N.V., 1951. Meoto-sarmatskiy mogil'nik u stanitsy Ust'-Labinskoy [Maeotian-Sarmatian Cemetery near the Village of Ust-Labinsk]. Materialy I issledovaniya po arkheologii SSSR [Materials and Research on Archaeology of the USSR], vol. 23, pp. 155-207.

Anfimov N.V., 1967. Otchet ob arkheologicheskikh issledovaniyakh, provedennykh v Krasnodarskom kraye v 1966 g. [The Report on the Archaeological Research, working in the Krasnodar Territory in 1966]. Arkhiv IA RAN. P-1, no. 3806.

Anfimov N.V., 1968. Otchet ob arkheologicheskikh rabotakh, svyazannykh s okhrannymi meropriyatiyami, provedennykh v $1967 \mathrm{~g}$. [The Report on the Archaeological Works, related to conservation activities, carried out in 1967]. Arkhiv IA RAN. P-1, no. 3807.

Anfimov N.V., 1973. Otchet o raskopkakh Pashkovskogo 5-go mogil'nika v 1972 g. [The Report on the Excavations of the $5^{\text {th }}$ Pashkovskaya Burial Ground in 1972]. Arkhiv IA RAN. P-1, no. 6505.

Bezuglov S.I., 2000. Pozdnesarmatskie mechi (po materialam Podon'ja) [The late Sarmatian's Swords]. Sarmaty i ih sosedi na Donu. Materialy i issledovanija po arheologii Dona [Sarmatians and their Neighbours on the Don. The Don Archaeology: New Materials and its Analysis], iss. 1. Rostov-on-Don, Terra Publ., pp. 169-193.

Voloshinov A.A., Masyakin V.V., Nenevolya I. I., 2007. Dva kompleksa s rimskimi importami iz Krasnozorinskogo nekropolya [Two Complexes with Roman Imports from the Krasnozorinsk Necropolis]. Drevnyaya Tavrika [Ancient Tavrika]. Simferopol, Universum Publ., pp. 303-318.

Ivanov A.V., 2008. O dlinnyih mechah bez metallicheskogo perekrestiya i navershiya (po materialam meotskih pamyatnikov Kubani) [On Long Swords Without a Metal Rain-Guard and Top (Based on Materials from the Maeotian Sites of the Kuban)]. Materialyi $i$ issledovaniya po arkheologii Severnogo Kavkaza [Materials and Research on the Archaeology of the North Caucasus], iss. 9. Armavir, Armavir State Pedagogical University, pp. 75-84.

Kosyanenko V.M., 1989. Novye materialy pozdneantichnogo vremeni s territorii g. Rostov-na-Donu [New Materials of Late Antique Time from the Territory of the City Rostov-on-Don]. Istoriko-arkheologicheskie issledovaniya $v$ Azove i na Nizhnem Donu [Historical and Archaeological Research in Azov and on the Lower Don], iss. 8. Azov, The Regional Museum of Azov, pp. 58-62.

Kosyanenko V.M., 2008. Nekropol' Kobiakova gorodischa (po materialam raskopok 1956-1962 gg.) [Nekropolis of the Kobyakov Settlement (on the Materials of 1956-1962)]. Donskie drevnosti [The Ancient of the Don], iss. 9. Azov, The Museum-Reserve of Azov. 554 p.

Krivosheev M.V., 2007. Vooruzhenie pozdnesarmatskogo vremeni Nizhnego Povolzh'ya [Arming Of The Late Sarmatian Time In The Lower Volga Region]. Vooruzhenie sarmatov: regional'naja tipologija i hronologija. Doklady k VI mezhdunarodnoj konferencii «Problemy sarmatskoj arheologii $i$ istorii» [The Sarmatians Arming: Regional Typology and Chronology. Reports for the VI International Conference "The Problems of the Sarmatian Archaeology and History"]. Chelyabinsk, SUSU, pp. 65-70.

Kropotov V.V., 2010. Fibuly sarmatskoy epokhi [Fibulae of the Sarmatian Epoch]. Kiev, ADEF-Ukraina Publ. 384 p.

Kropotov V.V., Skvortsov N.V., 2020. Sarmatskie pogrebeniya iz kurgannogo mogil'nika «Popov I» na Donu [Sarmatian Burials from the Cemetery “Popov I" on the Don]. Arkheologicheskoe nasledie. Antichnost'. Skify. Sarmaty [Archaeological Heritage. Antiquity. Scythians. Sarmatians], no. 1 (3). Voronezh, Nauchnaya kniga Publ., pp. 351-359.

Kunina N.Z., 1997. Antichnoe steklo v sobranii Ermitazha [Antique Glass in the Hermitage Collection]. Saint Petersburg, The State Hermitage Museum. 359 p. 
Kunina N.Z., Sorokina N.P., 1972. Steklyannye bal'zamarii Bospora [Glass of Balzamai of the Bosporus]. Trudy gosudarstvennogo Ermitazha [Transactions of the State Hermitage], vol. XIII, pp. 146-177.

Limberis N.Yu., Marchenko I.I., 2003. Steklyannye sosudy pozdneellinisticheskogo i rimskogo vremeni iz Prikuban'ya [Late Hellenistic and Roman Glass Vessels from Kuban Region]. Materialy ' $i$ issledovaniya po arkheologii Kubani. [Materials and Research on Archaeology of the Kuban Region], iss. 3. Krasnodar, Kuban State University, pp. 106-183.

Limberis N.Yu., Marchenko I.I., 2006. Tipologiya i khronologiya zheleznykh nakonechnikov kopiy iz pamyatnikov pravoberezh'ya Kubani [Typology and Chronology of the Iron Spearheads from the Sites of the Kuban River Right Bank]. Materialy ' $i$ issledovaniya po arkheologii Kubani [Materials and Research on Archaeology of the Kuban Region], iss. 6. Krasnodar, Kuban State University, pp. 152-181.

Limberis N.Yu., Marchenko I.I., 2012. Pogrebenie skifo-sarmatskogo vremeni na nekropole meotskogo gorodischa [Burial of a Sarmatian Horseman in the Cemetery of a Maeotian Hillfort]. Evrasia v sskifo-sarmatskoe vremya. Pamyati Iriny Ivanovny Guschinoy [Eurasia in the Scythian-Sarmatian Time. In Memory of Irina Ivanovna Gushchina]. Tpudy GIM, vol. 191, pp. 141-154.

Limberis N.Yu., Marchenko I.I., 2013. Vsadnicheskoe pogrebenie s umbonom iz Srednego Prikuban'ya [The Equestrian Burial with Shield-Boss from Middle Kuban]. Stratum plus, no. 4, pp. 105-115.

Limberis N.Yu., Marchenko I.I., 2015. Dve katakomby pozdnesarmatskogo vremeni iz Pashkovskogo mogil'nika № 1 [Two Catacombs of Late Sarmatian Time from Pashkovsky Burial Ground No. 2]. Vestnik Volgogradskogo gosudarstvennogo universiteta. Seriya 4. Istoriya. Regionovedenie. Mezhdunarodnye otnosheniya [Science Journal of Volgograd State University. History. Area Studies. International Relations], no. 5 (35), pp. 126-138. DOI: http://dx.doi.org/10.15688/jvolsu4.2015.5.12.

Limberis N.Yu., Marchenko I.I. 2018. Khronologiya ornamentirovannyh zerkal-podvesok s bokovoy ruchkoy iz meotskikh mogil'nikov pravoberezch'ya Kubani [The Chronology of Ornamented Mirror-Pendants with a Side Handle from Maeotian Burial Grounds in the Right Bank of the Kuban River]. Stratum plus, no. 4, pp. 201-218.

Limberis N.Yu., Marchenko I.I., 2019a. Pogrebeniya s mechami s kol'tsevym navershiem iz mogil'nika meotskogo gorodishcha Spornoye [Graves with Ring-Topped Swords from the Burial Ground of the Maeotian Fortified Settlement Spornoye]. Stratum plus, no. 4, pp. 189-209.

Limberis N.Yu., Marchenko I.I., 20196. Meotskie pogrebeniya so steklyannymi skifosami zubovskogo tipa [Maeotian Burials with Glass Skyphos of Zubovsky Type]. Nizhnevolzhskiy arheologicheskiy vestnik [The Lower Volga Archaeological Bulletin], vol. 18, no. 2, pp. 235-244. DOI: https://doi.org/10.15688/nav.jvolsu.2019.2.15.

Limberis N.Yu., Marchenko I.I., 2020. Khronologiya brasletov s konicheskimi shishechkami na kontsakh iz meotskikh pamyatnikov Prikuban'ya [Chronology of the Arm-rings with Conical Cones at the Ends from the Maeotian Monuments of the Kuban Region]. Arkheolohiya i davnya istoriya Ukrayiny [Archaeology and Ancient History of Ukraine], vol. 3 (36), pp. 423-430.

Malyshev A.A., 2008. Pogrebal'nyy inventar' Tsemdolinskogo nekropolya [Grave Goods from the Tsemdolina necropolis]. Aspurgiane na yugo-vostoke asiatskogo Bospora. Po materialam Tsemdolinskogo nekropolya [The Aspurgians on The South-East of Bosporus Asiaticus. Materials from the Tsemdolina a Nekropolis]. Moscow, IA RAS, pp. 136-180.

Maslov V.E., 1999. O datirovke izobrazheniy na poyasnyh plastinah iz Orlatskogo mogil'nika [On the Dating of Images on Belt Plates from the Orlat Burial Ground]. Evraziyskie drevnosti. 100 let B.N. Grakovu: arhivnye materialy, publikatsii, stat' $i$ [Eurasian Antiquities. 100 years of B.N. Grakov: Archival Materials, Publications, Articles]. Moscow, IA RAS, pp. 219-236.

Marchenko I.I., 1996. Siraki Kubani (Po materialam kurgannykh pogrebeniy Nizhney Kubani) [Siraces of the Kuban (Based on the Materials from Burial Mounds of the Lower Kuban)]. Krasnodar, Kuban State University. $336 \mathrm{p}$.

Simonenko A.V., 2010. Sarmatskiye vsadniki Severnogo Prichernomor'ya [Sarmatian Riders of North Pontic Region]. Saint Petersburg, Nestor-Historia. 328 p.

Skripkin A.S., 2000. Novye aspekty v izuchenii istorii material'noy kul'tury sarmatov [New Aspects in the Investigations of the History of Sarmatian Material Culture]. Nizhnevolzhskiy arkheologicheskiy vestnik [The Lower Volga Archaeological Bulletin], vol. 3, pp. 17-40.

Skripkin A.S., Klepikov V.M. 2020. Arkheologicheskiye pamiatniki Nizhnego Povolzh'ya II-I vv. do n.e. [Archaeological Sites of the Lower Volga Region of the $2^{\text {nd }}-1^{\text {st }}$ Centuries BC and some Ethnic Issues of the 
Sarmatians]. Arkheolohiya i davnya istoriya Ukrayiny [Archaeology and Ancient History of Ukraine], vol. 3 (36), pp. 214-222.

Symonovich E.A., 1983. Naselenie stolitsy pozdneskifskogo tsarstva (po materialam Vostochnogo mogil'nika Neapolya Skifskogo) [The Population of the Capital of the Late Scythian Kingdom (Based on the Materials of the Eastern Cemetery of Scythian Naples)]. Kiev, Naukova Dumka Publ. 175 p.

Trufanov A.A., 2009. Khronologiya mogil'nikov Predgornogo Kryma I v. do n.e. - III v. n.e. [Chronology of Cemeteries of Crimean Foothills of the $1^{\text {st }} \mathrm{c}$. BC $-3^{\text {rd }}$ c. AD]. Stratum plus, no. 4, pp. 117-329.

Khazanov A.I., 1971. Ocherki voennogo dela sarmatov [Essays on Military Affairs of the Sarmatians]. Moscow, Nauka Publ. 169 p.

Almgren O., 1923. Studien über nordeuropäische Fibelformen der ersten nachchrislichen Jahrhunderte mit Berücksicktigung der provinzialrömischen und südrussischen Formen. Mannus-Bibliothek. Bd. 32. Leihzig, Curt Kabitzsch. $254 \mathrm{~S}$.

Dusenbery E.B., 1967. Ancient Glass from Cemeteries of Samophfrace. Journal of Glass Studies, vol. 9, pp. 34-49.

Dusenbery E.B., 1998. Samophrace. II. The necropoleis. The necropoleis and catalogues of burials. Catalogues of Objects by categories. Princeton: Princeton University Press. $1252 \mathrm{p}$.

Grose D.F., 1989. Early Ancient Glass: core-formed, rod-formed, and cast vessels and objects from late Bronze Age to the early Roman Empire, 1600 B.C. to A.D. 50. New York, Hudson Hill Press. 453 p.

Hayes J.W., 1975. Roman and Pre-Roman Glass in the Royal Ontario Museum. Toronto, Royal Ontario Museum. $229 \mathrm{p}$.

Fünfschilling S., 2015. Die römischen Gläser aus Augst und Kaiseraugst. Forschungen in Augst. Bd. 51. August : Museum Augusta Raurica. 711 s.

Ettlinger E., 1973. Die römischen Fibeln in der Schweiz. Bern, Francke. 198 s.

Isings C., 1957. Roman Glass from Dated Finds. Djakarta, Groningen. 183 p.

Marčenko I.I., Limberis N.Ju., 2008. Römische importe in sarmatischen und maiotischen Denkmälern des Kubangebietes. Siminenko A., Marčenko I.I., Limberis N.Ju. Römische Importe in sarmatischen und maiotischen Gräbern. Archäologie in Eurasien. Mainz, Philipp von Zabern. Bd. 25. S. 265-400, 222 taf.

Riha E., 1994. Die römischen Fibeln aus Augst und Kaiseraugst. Die Neufunde seit 1975. Forschungen in Augst. Bd. 18. August, Museum Augusta Raurica. 206 s.

Rotroff S.I., 1997. Hellenistic Pottery. Athenian and Imported Wheelmade Table Ware and Related Material. The Athenian Agora. Vol. XXIX. Princeton, New Jersey, The American school of classic studies in Athens. 979 p.

Robinson H.S., 1959. Pottery of the Roman period chronology. The Athenian Agora. Vol. V. Princeton, New Jersey, The American school of classic studies in Athens. 149 p.

Rütti B., 1991. Die römischen Gläser aus Augst und Kaiseraugust. Forschungen in Augst. Bd. 13. Nr. 1. August : Museum Augusta Raurica. 370 p.

Thompson H.A., 1934. Two Centuries of Hellenistic Pottery. The American Excavation in the Athenian Agora. Fifth report. Hesperia. Vol. III. No. 4. Athens, The American school of classic studies in Athens, pp. 311-480. 
N.Yu. Limberis, I.I. Marchenko, A.V. Kondratenko. Swords and Daggers Without a Metal Pommel

\section{Information About the Authors}

Natalya Yu. Limberis, Senior Researcher, Scientific Research Institute of Archaeology, Kuban State University, Stavropolskaya St, 149, 350040 Krasnodar, Russian Federation, limberis2@mail.ru, https://orcid.org/0000-0003-0395-315X

Ivan I. Marchenko, Candidate of Sciences (History), Professor, Department of World History and International Relations, Kuban State University, Stavropolskaya St, 149, 350040 Krasnodar, Russian Federation,meot@mail.ru, https://orcid.org/0000-0001-7319-5214

Artem V. Kondratenko, Junior Researcher, Scientific Research Institute of Archaeology, Kuban State University, Stavropolskaya St, 149, 350040 Krasnodar, Russian Federation, artkondratenko@yandex.ru,https://orcid.org/0000-0003-0674-2673

\section{Информация об авторах}

Наталья Юрьевна Лимберис, старший научный сотрудник НИИ археологии, Кубанский государственный университет, ул. Ставропольская, 149, 350040 г. Краснодар, Российская Федерация, limberis2@mail.ru, https://orcid.org/0000-0003-0395-315X

Иван Иванович Марченко, кандидат исторических наук, профессор кафедры всеобщей истории и международных отношений, Кубанский государственный университет, ул. Ставропольская, 149, 350040 г. Краснодар, Российская Федерация, meot@mail.ru, https://orcid.org/0000-0001-7319-5214

Артем Викторович Кондратенко, младший научный сотрудник НИИ археологии, Кубанский государственный университет, ул. Ставропольская, 149, 350040 г. Краснодар, Российская Федерация, artkondratenko@yandex.ru, https://orcid.org/0000-0003-0674-2673 